\begin{tabular}{lll}
\hline VOLUME 21 & No. 2, 25 Agustus 2015 & Halaman 61-144 \\
\hline
\end{tabular}

Daftar Isi - i

Editorial - ii

Aksesibilitas Pemilu 2014 Dan Implikasinya Terhadap Ketahanan Politik (Studi Tentang Persepsi Mahasiswa Penyandang Disabilitas Di Pusat Layanan Difabel UIN Sunan Kalijaga Yogyakarta) - 61-77

Mario Merly

Efektivitas Pemanfaatan Biogas Untuk Menunjang Ketahanan Energi (Studi Di Desa Pendoworejo Kecamatan Girimulyo Kabupaten Kulon Progo Daerah Istimewa Yogyakarta) - 78-88

Dyah Sri Palupi

Diskresi Anggota Kepolisian Negara Republik Indonesia Dalam Penanganan Aksi Unjuk Rasa Dan Implikasinya Terhadap Ketahanan Wilayah (Studi Di Kepolisian Resort Kota Yogyakarta) - 89-106 Legowo Saputro

Dampak Pengalihan Fungsi Lahan Sawah Pada Produksi Padi Sampai Tahun 2018 Dan Implikasinya Terhadap Ketahanan Pangan Wilayah (Studi Di Kecamatan Jaten Kabupaten Karanganyar Propinsi Jawa Tengah) - 107-117 Catur Setyo Wibowo

Penerapan E-Procurement Dalam Proses Pengadaan Barang Dan Jasa Pemerintah Guna Mendukung Ketahanan Tata Pemerintahan Daerah (Studi Pada Unit Layanan Pengadaan Barang Dan Jasa Pemerintah Kabupaten Penajam Paser Utara Provinsi Kalimantan Timur) - 118-127 Rahmat Hidayat

Peran Pemuda Dalam Mengembangkan Eco Edu Wisata Mangrove Dan Implikasinya Terhadap Ketahanan Lingkungan Daerah (Studi Pada Perkumpulan Pemuda Peduli Lingkungan “Prenjak” Dusun Tapak, Kelurahan Tugurejo, Kecamatan Tugu, Kota Semarang, Provinsi Jawa Tengah) - 128-141 Fitriyani

Indeks -142 - 


\begin{tabular}{lll}
\hline VOLUME 21 & No. 2, 25 Agustus 2015 & Halaman 61-144 \\
\hline
\end{tabular}

\section{EDITORIAL}

Jurnal Ketahanan Nasional Volume 21, Nomor 2, Agustus 2015 ini menghadirkan tema politik, lingkungan, dan pemerintahan, berisi hasil penelitian Mario Merly, Dyah Sri Palupi, Legowo Saputro, Catur Setyo Wibowo, Rahmat Hidayat, dan Fitriyani.

Mario Merly meneliti tentang persepsi mahasiswa penyandang disabilitas terhadap aksesbilitas pemilu tahun 2014, dan dikaitkan dengan ketahanan politik, dilakukan di Pusat Layanan Difabel UIN Sunan Kalijaga Yogyakarta. Dyah Sri Palupi meneliti tentang efektivitas pemanfaatan biogas untuk menunjang ketahanan energi, dilakukan di Desa Pendoworejo, Kecamatan Girimulyo, Kabupaten Kulon Progo, Daerah Istimewa Yogyakarta. Legowo Saputro meneliti tentang diskresi anggota kepolisian Negara Republik Indonesia dalam menangani aksi unjuk rasa, dan dikaitkan dengan ketahanan wilayah, dilakukan di kepolisian resort Kota Yogyakarta. Catur Setyo Wibowo meneliti tentang dampak pengalihan fungsi lahan sawah pada produksi padi sampai tahun 2018, dan dikaitkan dengan ketahanan pangan wilayah, dilakukan di Kecamatan Jaten, Kabupaten Karanganyar, Provinsi Jawa Tengah. Rahmat Hidayat meneliti tentang penerapan e-procurement dalam proses pengadaan barang dan jasa pemerintah untuk mendukung ketahanan tata pemerintahan daerah, dilakukan pada unit layanan pengadaan barang dan jasa pemerintah Kabupaten Penajam Paser Utara, Provinsi Kalimantan Timur. Akhirnya, Fitriyani meneliti tentang peran pemuda dalam mengembangkan eco edu wisata mangrove, dan dikaitkan dengan ketahanan lingkungan daerah, dilakukan pada perkumpulan pemuda peduli lingkungan “Prenjak”, Dusun Tapak, Kelurahan Tugurejo, Kecamatan Tugu, Kota Semarang, Provinsi Jawa Tengah.

Semoga kehadiran Jurnal Ketahanan Nasional ini dapat menambah dan memperluas cakrawala ilmu pengetahuan kita. 


\title{
AKSESIBILITAS PEMILU 2014 DAN IMPLIKASINYA TERHADAP KETAHANAN POLITIK (Studi Tentang Persepsi Mahasiswa Penyandang Disabilitas Di Pusat Layanan Difabel UIN Sunan Kalijaga Yogyakarta)
}

\author{
Mario Merly \\ Dinas Pendidikan Pemuda dan Olahraga Provinsi Maluku \\ E-mail: bigmayo@gmail.com
}

\begin{abstract}
Accessibility was still a problem in the implementation of the 2014 elections. Inequality to elections accessibility for persons with disabilities would certainly lead to a perception of their own against the elections. This research was qualitative descriptive study using interviews and observation methods. Making the subject of research conducted by purposive sampling in accordance with the desired criteria researchers. Students with disabilities badly assess implementation legislation had many set of accessibility. The regulatory footing was not able to be implemented properly by the elections organizers to designed the elections accessible for persons with disabilities. It should be consideration was the attitude of political student disability has been good enough. When the accessibility policies remained ignored and not a concern of government, eventually the role of political student disability could be vulnerable as intangible attitude lose confidence (public trust) against the government. The implications of this affecting very fragile political resilience, because without public trust and important key in building the democratic would not materialize.
\end{abstract}

Keywords: Perceptions, Accessibility, Elections, Political Resilience.

\begin{abstract}
ABSTRAK
Aksesibilitas masih menjadi permasalahan dalam pelaksanaan Pemilu 2014. Ketimpangan terhadap aksesibilitas Pemilu bagi para penyandang disabilitas tentunya akan menimbulkan sebuah persepsi tersendiri mereka terhadap pelaksanaan Pemilu. Penelitian ini adalah penelitian deskriptif kualitatif dengan menggunakan metode wawancara dan observasi. Pengambilan subyek penelitian dilakukan secara purposive sampling sesuai dengan kriteria yang diinginkan peneliti. Hasil penelitian menyimpulkan bahwa mahasiswa penyandang disabilitas masih menilai buruk implementasi perundang-undangan yang telah banyak mengatur aksesibilitas. Pijakan regulasi tidak mampu dilaksanakan dengan baik oleh penyelenggara Pemilu untuk mendesain Pemilu yang aksesibel bagi penyandang disabilitas. Hal yang patut diperhatikan adalah sikap politik mahasiswa penyandang disabilitas telah cukup baik. Ketika kebijakan aksesibilitas tetap diabaikan dan tidak menjadi perhatian pemerintah, maka pada akhirnya peran politik mahasiswa penyandang disabilitas bisa menjadi rentan karena berwujud sikap kehilangan kepercayaan (public trust) terhadap pemerintah. Implikasi terhadap hal ini sangat rentan mempengaruhi ketahanan politik, karena tanpa kepercayaan publik maka kunci penting dalam membangun masyarakat yang demokratis tidak akan terwujud.
\end{abstract}

Kata Kunci: Persepsi, Aksesibilitas, Pemilu, Ketahanan Politik. 


\section{PENGANTAR}

Para penyandang disabilitas sebagai bagian dari warga negara Indonesia berhak terlibat aktif dalam berkehidupan politik. Pasal 43 ayat 1 UU Nomor 39 Tahun 1999 tentang Hak Asasi Manusia telah menerangkan secara tegas bahwa setiap warga negara berhak mendapatkan kesempatan yang sama dalam pemerintahan, baik untuk dipilih maupun memilih. Pengesahan Konvensi Mengenai Hak-hak Penyandang Disabilitas dalam UU Nomor 19 Tahun 2011 juga telah menjamin hak pilih para penyandang disabilitas dalam Pemilu. Undang-Undang ini juga menyebutkan negara memiliki kewajiban untuk mewujudkan hak penyandang disabilitas dan menjamin kesamaan hak dan kebebasan yang mendasar, yang salah satunya adalah hak untuk mendapatkan perlindungan dan pelayanan dalam Pemilu.

Pemilih penyandang disabilitas menjadi bagian penting dalam mengukur sukses tidaknya pelaksanaan Pemilu. Namun, pijakan regulasi selama ini rupanya tidak berbanding lurus dengan aspek teknis pelaksanaannya, bahkan tidak sejalan dengan tingkat kesadaran para kontestan Pemilu itu sendiri. Dapat dikatakan bahwa kapasitas pengetahuan akan isu penyandang disabilitas, baik bagi para pelaksana, pengawas, maupun pesertanya masih jauh di bawah standar. Jika merujuk kepada buku "Accessible Elections for Persons with Disabilities in Indonesia" (Aksesibilitas Pemilu untuk Difabel di Indonesia) yang disusun oleh Pusat Pemilihan Umum Akses Penyandang Cacat (PPUA PENCA) 2013, maka sekurang-kurangnya ada 4 hambatan yang akan dihadapi pemilih dan kandidat penyandang disabilitas pada Pemilu, yakni Hambatan Legal, Hambatan
Informasi, Hambatan Fisik, dan Hambatan Sikap. Keempat hambatan inilah yang berpotensi mereduksi keterlibatan penyandang disabilitas dalam Pemilu, dan masih tak mampu diruntuhkan walau aspek legalnya telah didukung lewat regulasi yang dibuat.

Berdasarkan temuan The Asia Fondation, 35\% lebih para penyandang disabilitas tidak mempunyai akses ke Pemilu atau tidak paham akan Pemilu, artinya masih terdapat 35\% jumlah penyandang disabilitas di Indonesia yang memiliki hak suara namun tidak mampu menggunakan hak suaranya dalam Pemilu 2014 (sumber: http://rumahopini.com). Permasalahan ini semakin kompleks ketika peran penyelenggara Pemilu ditengarai masih tidak mampu menyediakan pelayanan yang aksesibel dalam Pemilu 2014 bagi penyandang disabilitas, misalnya ketika KPU pusat maupun KPU di daerah belum maksimal menyediakan Template Braille atau surat suara bagi para pemilih tunanetra pada Pemilu Legislatif 2014. Beberapa organisasi masyarakat banyak mengkritisi seperti halnya kutipan di bawah ini:

“Persatuan Tunanetra Indonesia (Pertuni)
mendesakKomisi Pemilu(KPU)menyediakan
fasilitas serta surat suara bagi kaum difabel,
terutama kaum tunanetra. Selama ini kertas
suara yang disediakan oleh KPU bagi
penyandang tunanetra masih sangat minim.
"Memang untuk beberapa Pemilu seperti
Pilpres dan DPD sudah ada seperti huruf
timbul, bukan braile, jadi bisa diraba. Tapi
untuk DPR RI, DPRD, dan seterusnya itu
tidak ada. Itu sulit karena banyak sekali,”
kata Ketua I Pertuni Mochammas Oce
Soedioto kepada Dresnews.com”. (sumber:
http://gresnews.com).

Cara pandang terhadap permasalahan demikian tentunya akan mempengaruhi sikap 
Mario Merly -- Aksesibilitas Pemilu 2014 Dan Implikasinya Terhadap Ketahanan Politik (Studi Tentang Persepsi Mahasiswa Penyandang Disabilitas Di Pusat Layanan Difabel UIN Sunan Kalijaga Yogyakarta)

pemilih para penyandang disabilitas terhadap proses Pemilu. Permasalahan akan timbul ketika cara pandang ini menghasilkan sikap apatis terhadap Pemilu dan berkembang dalam diri para penyandang disabilitas terutama kaum muda. Kondisi ini tentunya bukan sesuatu yang dikehendaki dalam proses demokrasi, karena Pemilu merupakan wujud partisipasi politik dan dicirikan oleh besarnya partisipasi kaum muda di dalamnya; kaum yang pada saat sekarang ini dituntut untuk membentuk sikap dan keyakinan dalam menentukan arah politik.

Mas’oed, (2003: 184) menyatakan bahwa kaum muda berada pada lapisan umur yang memungkinkan untuk menjadi energetic dan cocok untuk menjadi pelopor perbaikan keadaan. Penjelasan itu berlaku bagi seluruh kaum muda bangsa Indonesia termasuk dari mereka yang juga memiliki kondisi disabilitas fisik, terutama golongan cendekiawan kaum muda yakni mahasiswa sebagai bagian dari generasi muda yang sedang mempersiapkan diri untuk memasuki kehidupan bermasyarakat secara penuh dan memiliki peranan dalam memajukan bangsa. Keterbatasan aksesibilitas Pemilu akan sangat berpengaruh terhadap persepsi kaum muda penyandang disabilitas terhadap pelaksanaan Pemilu di Indonesia.

Implikasi terhadap hal demikian jika merujuk pada penjelasan dari Lemhannas yang menyatakan bahwa faktor-faktor yang mempengaruhi ketahanan politik dalam negeri salah satunya adalah timbulnya keresahan masyarakat, terutama keresahan di kalangan generasi muda yang dapat menimbulkan gejolak sosial (Lemhannas RI, 1997: 55). Contoh kasus yang dapat menguatkan argumen ini adalah tindakan demonstrasi sebagai bentuk keresahan masyarakat penyandang disabilitas oleh Aliansi Pembela Hak-Hak Disabilitas (Alpadi) yang memprotes kebijakan rekrutmen CPNS di Kantor Regional I Badan Kepegawaian Nasional (BKN) Sleman, Yogyakarta pada 17 Oktober 2014, dengan tuntutan agar para penyandang disabilitas diberikan kesempatan yang sama dengan masyarakat nondisabilitas dalam hal memperoleh pekerjaan (sumber: https://radarjogja.co.id).

Berkaca dari contoh kasus tersebut, tentunya permasalahan minimnya perangkat Pemilu yang belum aksesibel bagi penyandang disabilitas justru menurut peneliti juga bisa menjadi faktor yang dapat menimbulkan keresahan terutama dalamusaha mengakomodir hak politik penyandang disabilitas dalam Pemilu, padahal dari segi kuantitasnya jumlah penyandang disabilitas di Indonesia cukup tinggi.

Berdasarkan Organisasi Buruh Internasional (ILO) pada tahun 2010 setidaknya terdapat 10 persen penduduk Indonesia atau sekitar 24 juta orang merupakan penyandang disabilitas (Ishak Salim, 2014: 3). Jika merujuk pada temuan The Asia Fondation, maka masih terdapat sekitar 8,4 juta jumlah penyandang disabilitas di Indonesia yang masih dihadapkan dengan kesulitan akses ketika memilih pada Pemilu. Jumlah tersebut merupakan jumlah yang cukup besar untuk dijadikan pertimbangan dalam meraih partisipasi dalam Pemilu.

Dengan mengetahui persepsi mahasiswa penyandang disabilitas terhadap permasalahan aksesibilitas Pemilu akan sangat erat kaitannya dengan ketahanan politik di masa mendatang. Kaitan penting yang dimaksud adalah, apakah hasil persepsi mahasiswa penyandang disabilitas tentang aksesibilitas Pemilu juga 
akan berimplikasi terhadap sikap dan kesadaran partisipasi politik mereka? Apakah juga akan berimplikasi pada kepercayaan kaum muda mahasiswa penyandang disabilitas terhadap legitimasi pemerintah? Mengingat masih terdapat 35\% jumlah penyandang disabilitas yang masih belum menikmati hak akses yang baik ketika Pemilu. Tentunya kajian terhadap Ketahanan Politik menuntut adanya sebuah kesadaran politik, disiplin nasional, dan dinamika sosial yang tinggi, sehingga tumbuh motivasi dan aktivitas konstruktif yang membangkitkan partisipasi aktif dalam pembangunan nasional (Hermawan, 2014: 33).

Dengan latar belakang tersebut, penelitian ini mengambil judul Aksesibilitas Pemilu 2014 dan Implikasinya Terhadap Ketahanan Politik (Studi Tentang Persepsi Mahasiswa Penyandang Disabilitas di Pusat Layanan Difabel UIN Sunan Kalijaga Yogyakarta). Penelitian ini merupakan penelitian deskriptif kualitatif. Lokasi penelitian dilakukan di Pusat Layanan Difabel (PLD) UIN Sunan Kalijaga Yogyakarta. Pada penelitian ini, penentuan subjek menggunakan purposive sampling. Pengumpulan data dalam penelitian ini menggunakan metode wawancara (13 informan) dan observasi. Analisis data kemudian dilakukan melalui 3 alur, yaitu: reduksi data, penyajian data berupa hasil persepsi mahasiswa penyandang disabilitas tentang aksesibilitas Pemilu 2014 dan hasil persepsi mahasiswa penyandang disabilitas tentang implikasi aksesibilitas Pemilu 2014 terhadap Ketahanan Politik, serta penarikan kesimpulan.

\section{PEMBAHASAN}

\section{Teori Persepsi}

Menurut Jalaludin Rakhmat (2003: 51) persepsi adalah pengalaman tentang objek, peristiwa, atau hubungan yang diperoleh dengan menyimpulkan informasi dan menafsirkan pesan. Berdasarkan penjabaran teori tersebut, dapat disimpulkan bahwa persepsi merupakan penyimpulan informasi berdasarkan pengalaman-pengalaman tentang objek maupun peristiwa yang pernah diperoleh. Kaitannya dengan penelitian ini, maka yang dikatakan persepsi ialah penyimpulan informasi mahasiswa penyandang disabilitas tentang aksesibilitas Pemilu 2014 dan penyimpulan informasi mahasiswa penyandang disabilitas tentang implikasi aksesibilitas Pemilu 2014 terhadap ketahanan politik.

\section{Aksesibilitas Pemilu Bagi Penyandang Disabilitas}

Pemilu yang memberikan kesamaan kesempatan kepada penyandang disabilitas adalah Pemilu yang nondiskriminasi dan memberikan akses atau kemudahan kepada penyandang disabilitas guna terpenuhinya hak memilih, hak dipilih dan hak untuk menjadi penyelenggara Pemilu. Berdasarkan pernyataan tersebut, maka penyelenggara Pemilu wajib menyediakan perangkat yang mampu memenuhi hak politik penyandang disabilitas.

Menurut Buku Panduan Akses Pemilu PPUA PENCA (Ariani, 2009), agar penyandang disabilitas dapat berpartisipasi penuh melaksanakan hak politiknya dalam hal ini hak untuk memilih dan hak untuk dipilih dalam Pemilu, maka sarana aksesibilitas yang wajib disediakan penyelenggara Pemilu adalah: Pertama, Aksesibilitas nonfisik, yang meliputi akses pemilih penyandang disabilitas cerdas berkualitas, persyaratan menjadi calon tidak membatasi hak politik penyandang cacat, pendidikan pemilih, sosialisasi dan informasi, iklan Pemilu, dan petugas KPPS 
Mario Merly -- Aksesibilitas Pemilu 2014 Dan Implikasinya Terhadap Ketahanan Politik (Studi Tentang Persepsi Mahasiswa Penyandang Disabilitas Di Pusat Layanan Difabel UIN Sunan Kalijaga Yogyakarta)

yang berprespektif penyandang disabilitas. Kedua, Aksesibilitas fisik, yang meliputi akses TPS dan alat bantu kertas suara.

Berdasarkan jenis aksesibilitas yang wajib diperuntukkan bagi para penyandang disabilitas di atas, peneliti mencoba mengaitkan keseluruhan jaminan hak aksesibilitas dengan cara menggali persepsi mahasiswa penyandang disabilitas terhadap realita pelaksanaan jenisjenis aksesibilitas tersebut.

\section{Ketahanan Politik}

Lembaga Ketahanan Nasional (Lemhannas) mengartikan ketahanan politik sebagai kondisi dinamik kehidupan politik bangsa yang berisi keuletan dan ketangguhan yang mengandung kemampuan mengembangkan kekuatan nasional dalam menghadapi dan mengatasi tantangan, ancaman, hambatan, serta gangguan yang datang dari luar dan dari dalam yang langsung maupun tidak langsung untuk menjamin kelangsungan kehidupan politik bangsa dan negara Republik Indonesia berdasarkan Pancasila dan UUD 1945 (Sunardi, 1997).

Untuk mengkaji implikasi terhadap ketahanan politik, peneliti menggunakan penjelasan dari beberapa teori pendukung yaitu:

Pertama, Kajian Tentang Implikasi Terhadap Pendidikan Politik. Menurut Kartini Kartono (1996: 64), pendidikan politik adalah upaya edukatif yang internasional, disengaja dan sistematis untuk membentuk inividu sadar politik, dan mampu menjadi pelaku politik yang bertanggung jawab secara etis atau moril dalam mencapai tujuan-tujuan politik. Berdasarkan pemaparan definisi di atas, esensi dari pendidikan politik adalah agar setiap warga negara memiliki kemampuan untuk memahami situasi sosial politik sehingga dapat mengaktualisasikan diri dengan jalan ikut berpartisipasi secara aktif dalam bidang politik. Singkat kata, pendidikan politik dapat membentuk sikap dan kesadaran partisipasi politik masyarakat dalam kehidupan berbangsa dan bernegara.

Sikap politik dan kesadaran partisipasi politik menjadi tolak ukur keberhasilan dari implementasi pendidikan politik itu sendiri. Berangkat dari pemahaman ini Sudijono Sastroadmojo (1995: 4) menjelaskan bahwa sikap politik dapat dinyatakan sebagai kesiapan untuk bereaksi terhadap objek tertentu yang bersifat politik, sebagai hasil penghayatan terhadap objek tersebut. Dengan munculnya sikap politik tertentu akan diperkirakan perilaku politik apa yang sekiranya akan muncul.

Di samping sikap politik, terdapat kajian lain mengenai partisipasi politik sebagai bentuk perilaku politik. Perilaku dikatakan sebagai buah dari sikap, dimana sikap hanya merupakan kecenderungan untuk bertindak dan hanya bersifat internal, sedangkan perilaku merupakan implementasi dari tindakan. Miriam Budiarjo (1981: 1) mengartikan partisipasi politik sebagai kegiatan seseorang atau sekelompok orang untuk ikut secara aktif dalam kehidupan politik, yaitu dengan jalan memilih pimpinan negara dan secara langsung atau tidak langsung mempengaruhi kebijakan pemerintah (public policy).

Faktor-faktor yang mempengaruhi tinggi rendahnya partisipasi politik seseorang ialah kesadaran politik dan kepercayaan kepada pemerintah. Tinggi rendahnya kedua faktor tersebut, Paigie (dalam Surbakti, Ramlan. 1992: 144) membagi partisipasi menjadi empat tipe: (1) partisipasi aktif, yaitu kesadaran politik dan 
kepercayaan kepada pemerintah oleh seseorang sangatlah tinggi; (2) partisipasi cenderung pasif-tertekan (apatis), yaitu kesadaran politik dan kepercayaan kepada pemerintah rendah; (3) partisipasi militan-radikal, yaitu partisipasi yang memiliki kesadaran politik tinggi tetapi kepercayaan terhadap pemerintah sangat rendah; (4) partisipasi tidak aktif (pasif), apabila kesadaran politik sangat rendah tetapi kepercayaan terhadap pemerintah sangat tinggi.

Kaitan penjelasan beberapa teori di atas terhadap ketahanan politik adalah, bahwa minimnya aksesibilitas akan membatasi ruang pengetahuan serta proses pembelajaran dan pemahaman politik bagi kalangan penyandang disabilitas karena para penyandang disabilitas jelas sangat membutuhkan akses dalam menunjang pendidikan politik. Hal ini tentunya mempengaruhi ketahanan politik, artinya pendidikan politik dibutuhkan dalam upaya mewujudkan kesadaran politik. Pengetahuan berupa pendidikan politik dan kepedulian terhadap penyandang disabilitas sangatlah membantu penyandang disabilitas yang ingin melaksanakan hak politiknya. Tidak adanya platform atau perspektif disabilitas dalam membuat sebuah kebijakan politik tentunya akan membuat kondisi ketahanan politik semakin rentan karena tidak adanya keberpihakan terhadap pengembangan pendidikan politik bagi penyandang disabilitas.

Sikap politik dan partisipasi politik dianalisis berdasarkan hasil persepsi mahasiswa penyandang disabilitas tentang implikasi aksesibilitas Pemilu 2014 terhadap ketahanan politik dan digunakan sebagai indikator pendukung untuk menilai keberhasilan implementasi pendidikan politik.
Penilaian dilakukan dengan menilai sikap politik mahasiswa penyandang disabilitas dalam menghadapi Pemilu 2014 berdasarkan penjelasan Sudijono Sastroadmojo dan menilai keterlibatan aktif mahasiswa penyandang disabilitas dalam menggunakan hak pilih berdasarkan klasifikasi tipe partisipasi menurut Paigie (dalam Surbakti, Ramlan).

Kedua, Kajian tentang Pelaksanaan Pemilu dan Demokrasi. Ibnu Tricahyo (2009: 6) menyatakan bahwa Pemilu merupakan instrumen mewujudkan kedaulatan rakyat yang bermaksud membentuk pemerintahan yang sah serta sarana mengartikulasikan aspirasi dan kepentingan rakyat. Pemilu berhubungan dengan kedudukan penting warga negara dalam suatu negara demokrasi, dan esensi dari demokrasi ialah kedaulatan ada di tangan rakyat, demikian dapat dipahami dari pemahaman historis terhadap pasal 1 ayat 2 UUD 1945.

Kajian tentang implikasi terhadap ketahanan politik, Lembaga Ketahanan Nasional (Lemhannas) menegaskan bahwa pelaksanaan Pemilu yang langsung, umum, bebas, rahasia, jujur dan adil (Luber Jurdil) sangat mempengaruhi stabilitas politik dalam negeri. Apabila asas Luber itu tidak terjamin maka akan timbul keresahan dan kondisi ketahanan politik juga akan semakin rentan (Lemhannas RI, 1997: 54). Penegasan ini menandakan bahwa implikasi terhadap asas Pemilu sebagai cerminan sistem politik demokrasi Indonesia sangat erat kaitannya dengan aksesibilitas Pemilu bagi kalangan penyandang disabilitas. Bagaimanakah realita pelaksanaan prinsip-prinsip Pemilu ini bagi para penyandang disabilitas berdasarkan hasil persepsi mahasiswa penyandang disabilitas? Minimnya aksesibilitas dalam pelaksanaan 
Mario Merly -- Aksesibilitas Pemilu 2014 Dan Implikasinya Terhadap Ketahanan Politik (Studi Tentang Persepsi Mahasiswa Penyandang Disabilitas Di Pusat Layanan Difabel UIN Sunan Kalijaga Yogyakarta)

Pemilu bagi kalangan penyandang disabilitas dapat mempengaruhi ketahanan politik jika Pemilu sendiri tidak menjamin keberhasilan pelaksanaan asas-asas Luber Jurdil tersebut.

Selain prinsip-prinsip Pemilu, menurut Lemhannas bahwa salah satu faktor yang juga mempengaruhi politik dalam negeri adalah keberhasilan pelaksanaan Pemilu (Lemhannas RI, 1997: 55). Kajian terhadap keberhasilan pelaksanaan Pemilu dalam penelitian ini menggunakan penjelasan dari Afan Gaffar (1999: 7) yang menyimpulkan salah satu prasyarat untuk mengamati ada tidaknya demokrasi dalam suatu pemerintahan negara, adalah dapat menikmati hak-hak dasar; dalam suatu negara yang demokratis, setiap warga dapat menikmati hak-hak dasar mereka secara bebas. Penjelasan lain yang digunakan sebagai indikator dalam mengukur keberhasilan pelaksanaan Pemilu adalah menurut Huntington (dalam Z.A. Maulani, 1996: 32) yang menyoroti ciri penting yang melekat pada demokrasi, yaitu hadirnya partisipasi masyarakat. Untuk memungkinkan partisipasi rakyat secara efektif dibutuhkan syarat penting yakni keterbukaan dan kebebasan dalam memperoleh akses informasi.

Penjelasan teori dari Lemhannas, Afan Gaffar, dan Huntington (dalam Z.A. Maulani) di atas digunakan peneliti sebagai pedoman dalam memperoleh informasi mengenai keberhasilan pelaksanaan Pemilu bagi penyandang disabilitas berdasarkan hasil persepsi mahasiswa penyandang disabilitas tentang implikasi aksesibilitas Pemilu 2014 terhadap ketahanan politik yakni implikasi terhadap pelaksanaan pemilu dan demokrasi.

Ketiga, Kajian Tentang Implikasi Terhadap Legitimasi Pemerintah. Kondisi ketahanan politik juga dapat dikatakan tangguh apabila ada keseimbangan, keserasian, dan keselarasan hubungan antara penyelenggaraan pemerintahan negara dan masyarakat. Dalam rangka mewujudkan ketahanan politik, konsepsinya adalah perlunya kehidupan politik bangsa yang sehat dan dinamis yang mengandung kemampuan memelihara stabilitas politik antara pemerintah dengan rakyat berdasarkan Pancasila dan UUD 1945. Menurut Subagyo, dkk, (Hermawan, 2014: 17) ketahanan politik akan terwujud jika pemerintah memiliki legitimasi yang kuat dan didukung dengan kebijakan yang sesuai dengan aspirasi rakyat, artinya segala bentuk penolakan dari rakyat sangat kecil. Dukungan atas legitimasi pemerintah dalam jurnal penelitian ini dikaji berdasarkan tingkat kepercayaan mahasiswa penyandang disabilitas terhadap kinerja pemerintah, pelayanan publik, dan kebijakan publik.

\section{Persepsi Mahasiswa Penyandang Disabilitas Tentang Aksesibilitas Pemilu 2014}

Persepsi tentang akses pemilih penyandang disabilitas cerdas berkualitas pada Pemilu 2014, menurut pandangan mahasiswa penyandang disabilitas akses demikian belum maksimal dilakukan oleh semua institusi lembaga pemerintahan baik itu KPU maupun partai politik sendiri sehingga akses pemilih cerdas dan berkualitas menuntut keterlibatan aktif mereka agar mau membekali diri dengan pengetahuan proses Pemilu secara mandiri. Mahasiswa penyandang disabilitas mengutarakan bahwa seharusnya ada upaya atau akses yang disediakan pemerintah untuk menjadikan penyandang disabilitas itu menjadi pemilih cerdas dan berkualitas. Akses-akses semacam itu bisa dilakukan dengan melalui diskusi publik terkait Pemilu. Langkah 
seperti itu banyak yang sudah dilakukan oleh organisasi-organisasi sosial penyandang disabilitas untuk memberikan pemahaman tentang arti Pemilu itu sendiri, contohnya seperti kegiatan-kegiatan temu inklusi dan lain sebagainya. Lebih lanjut menurut mahasiswa penyandang disabilitas, akses pemilih cerdas dan berkualitas tidak lantas menjadi tolak ukur yang diperuntukkan bagi penyandang disabilitas saja, namun tetap menjadi tanggung jawab setiap warga negara agar berkewajiban untuk mempunyai sikap penilaian politik yang baik ketika menghadapi Pemilu.

Persepsi tentang hak politik penyandang disabilitas untuk bisa ikut terpilih dalam Pemilu, menurut persepsi mahasiswa penyandang disabilitas sudah baik terakomodir dalam penjelasan perundang-undangan. Mahasiswa penyandang disabilitas menganggap hak akses untuk ikut dipilih secara legal formal sudah cukup baik bagi penyandang disabilitas untuk bisa ikut bersaing menjadi calon kandidat dalam Pemilu. Namun, syarat-syarat terkait hak politik penyandang disabilitas untuk bisa terpilih memiliki ragam persepsi yang berbeda dan mengalami ambiguitas. Redaksi undang-undang jelas tidak membatasi hak politik penyandang disabilitas untuk bisa ikut terpilih, namun paradigma medis kecacatan yang terbangun dalam masyarakat dan partai politik sendiri yang kemudian mempersepsikan salah redaksional undangundang itu, sehingga memanfaatkan hal ini dalam menghambat eksistensi hak politik penyandang disabilitas.

Esensi pendidikan pemilih dalam usaha memberikan kesadaran dan pengetahuan menjadi pemilih cerdas belum menjadi sebuah akses pendampingan yang baik dalam mensosialisasikan pendidikan pemilih bagi para penyandang disabilitas di Pemilu 2014. Perihal akses berupa pendidikan pemilih, pandangan mahasiswa penyandang disabilitas mengungkapkan bahwa tidak pernah menemukan keterlibatan KPU maupun partai politik dalam mensosialisasikan pendidikan pemilih bagi penyandang disabilitas. Beberapa mahasiswa penyandang disabilitas menyampaikan bahwa akses pendidikan pemilih hanya dilakukan melalui peran-peran organisasi sosial penyadang disabilitas saja. Akses pendidikan pemilih bagi kalangan pemilih penyandang disabilitas menurut pandangan mahasiswa tidak menjadi perhatian KPU sehingga pemilih penyandang disabilitas dengan tanpa informasi memadai soal pelaksanaan Pemilu dan visi-misi kandidat lebih menjadi pemilih dengan kategori swing voters (pemilih mengambang) ketimbang undecided voters (pemilih yang sedang memikirkan siapa calon yang tepat). Pemilih penyandang disabilitas dibiarkan mengambang tanpa perhatian memadai dari berbagai pihak agar dapat memaksimalkan pilihannya.

Mahasiswa penyandang disabilitas memandang bahwa peran KPU dan partai politik disinyalir juga tidak melakukan sosialisasi Pemilu 2014 secara maksimal kepada pemilih penyandang disabilitas. Asumsi yang menyederhanakan ini tentu keliru, mengingat sosialisasi hanya pada tataran teknis pemungutan dan tata cara prosedural memilih saja. Persepsi mahasiswa penyandang disabilitas mengungkapkan bahwa perlakuan akses informasi juga memang belum sepenuhnya inklusif diterima bagi mereka karena tidak mempertimbangkan cara pemilih mengakses informasi tersebut. Hal ini juga bergantung pada sikap mahasiswa penyandang disabilitas sendiri, karena seberapapun 
Mario Merly -- Aksesibilitas Pemilu 2014 Dan Implikasinya Terhadap Ketahanan Politik (Studi Tentang Persepsi Mahasiswa Penyandang Disabilitas Di Pusat Layanan Difabel UIN Sunan Kalijaga Yogyakarta)

inklusifnya akses informasi itu diberikan apabila tidak dipergunakan maka hasilnya akan sama saja.

Selain itu, persepsi mahasiswa penyandang disabilitas tentang layanan iklan Pemilu 2014 masih belum utuh memberikan pesan yang dapat mudah diterima oleh mahasiswa penyandang disabilitas karena tidak mempertimbangkan hambatan penginderaan yang dimiliki. Pembuatan iklan Pemilu tidak memuat materi yang mendeskripsikan adanya pemilih penyandang cacat. Pada media TV tidak terdapat running text dapat membantu penyampaian informasi kepada penyandang cacat tunarungu. Bentuk-bentuk iklan Pemilu yang berupa dialog, lagu (jingle) yang disiarkan melalui radio juga tidak memudahkan penyampaian informasi kepada penyandang tunanetra. Pandangan mahasiswa penyandang disabilitas terhadap iklan Pemilu belum sepenuhnya bisa diakses, terutama oleh penyandang tunanetra dan tunarunguwicara. Informasi iklan yang dilakukan melalui media cetak, elektronik berupa televisi dan radio kurang mempertimbangkan hambatan-hambatan bagi tunanetra dan tunarungu-wicara. Sebuah iklan Pemilu menurut mahasiswa penyandang disabilitas tidak memberikan pesan yang utuh yang bisa disampaikan. Ketika sebuah iklan Pemilu ditayangkan, informasi pesan melalui audio dan visual diberikan namun tidak terdapat sinergitas antara keduanya. Penafsiran berbeda ditangkap oleh penyandang disabilitas sehingga membutuhkan penjelasan lebih lanjut dari orang lain mengenai maksud dari iklan Pemilu yang ditayangkan.

Persepsi tentang kualitas kinerja layanan petugas KPPS pada Pemilu 2014 masih belum maksimal dan belum begitu baik. Mahasiswa penyandang disabilitas menganggap bahwa kualitas layanan petugas KPPS yang diberikan berbeda-beda, artinya beda TPS berbeda juga kualitas layanan yang diberikan. Kelemahan ini berujung pula pada ketidaksediaan aksesibilitas fisik maupun nonfisik dalam Pemilu. Hal ini menjadi momok yang selalu saja menjadi permasalahan klasik yang berulang terusmenerus dalam setiap pelaksanaan Pemilu. Ketika kualitas layanan petugas KPPS tidak berorientasi pada kebutuhan penyandang disabilitas, maka selama itu pula penyandang disabilitas tetap terjerumus pada paradigma pengampuan; paradigma yang tetap selalu akan menganggap bahwa penyandang disabilitas tidak mampu. Hal ini bergantung kepada perspektif terhadap isu kebutuhan akses para penyandang disabilitas yang dimiliki petugas KPPS dan sejauhmana peran KPU maupun KPUD dalam memberikan sosialisasi dalam rangka menyediakan Pemilu yang aksesibel bagi penyandang disabilitas.

Pandangan mahasiswa penyandang disabilitas terhadap aksesibilitas fisik Pemilu 2014 berupa kemudahan menjangkau TPS masih belum baik sepenuhnya dirasakan oleh semua kalangan penyandang disabilitas, khususnya di daerah-daerah yang pergerakan mengenai hak-hak akses kehidupan dan penghidupan penyandang disabilitas sangat minim. Pengalaman mahasiswa penyandang disabilitas khususnya tunanetra tidak terlalu menyulitkan mereka selama menjangkau dan melakukan pemungutan suara di lokasi TPS. Mobilitas untuk menjangkau TPS sangat dipengaruhi oleh informasi serta proses pendampingan yang dialami oleh tunanetra. Permasalahan aksesibilitas fisik berupa lokasi akses TPS justru dihadapi oleh mahasiswa penyandang tunarungu-wicara dengan 
mahasiswa tunadaksa. Penyandang disabilitas khusus tunarungu-wicara menanggapi bahwa akses lokasi memang tidak terlalu masalah bagi mereka, namun yang menjadi kesulitan bagi mereka adalah aktivitas yang terjadi di TPS kurang bisa menjamah ranah kepentingan penyandang tunarungu-wicara karena aktivitas yang terjadi hanya mengandalkan media audio atau suara dalam memberikan informasi. Proses pemungutan suara di lokasi TPS sangat jarang menggunakan media petunjuk yang memudahkan penyandang disabilitas tunarungu-wicara agar mengerti dan paham tentang tata cara yang harus dijalankan terlebih dahulu.

Pengalaman mahasiswa tunadaksa dalam menjangkau lokasi TPS sudah baik, namun kendala lainnya yang dihadapi ialah ketika melakukan proses pemungutan suara, kondisi bilik dan kotak suara yang untuk melakukan mobilitas dihadapkan dengan anak tangga sehingga hal ini kemudian menjadi tidak akses. Persepsi mahasiswa penyandang disabilitas menunjukkan bahwa akses lokasi TPS menjadi salah satu hal yang dapat mempengaruhi tingkat partisipasi penyandang disabilitas untuk turut aktif berpartisipasi. Apabila akses lokasi sudah baik maka juga mempengaruhi keterlibatan penyandang disabilitas untuk mau memberikan suaranya dalam Pemilu. Lebih lanjut pandangan terhadap akses lokasi agar lebih ramah terhadap penyandang disabilitas juga dipengaruhi oleh paradigma masyarakat dalam lingkup sosial kehidupan penyandang disabilitas khususnya keluarga dalam memberikan pendampingan serta informasi agar penyandang disabilitas mampu mengalami fungsi sosial yang baik ketika melakukan aktivitas politik seperti halnya Pemilu.
Persepsi mahasiswa penyandang disabilitas terhadap aksesibilitas alat bantu kertas suara dalam Pemilu 2014 belum sepenuhnya berhasil diterapkan. Terbukti ketika menghadapi Pemilu baik pileg dan pilpres, tidak semuanya akses fisik berupa alat bantu kertas suara disediakan di setiap TPS yang menjadi lokasi tempat pencoblosan. Bagi mahasiswa penyandang disabilitas, hal tersebut menjadi permasalahan yang kerap terjadi pada setiap momen pelaksanaan Pemilu. Isu mengenai aksesibilitas yang mulai didengungkan sejak Pemilu 2004 pun sampai dengan sekarang tak lepas dari permasalahan akses khususnya penyediaan alat bantu kertas suara Braille maupun Template. Pertimbangan anggaran yang dijadikan argumen balasan pihak penyelenggara Pemilu ketika tidak mampu dalam menyediakan akses kertas suara.

Mahasiswa penyandang disabilitas masih memandang aksesibilitas belum menjadi perhatian yang baik bagi pemerintah walau sejak Pemilu 2004 sudah mulai didengungdengungkan, namun implementasi terkait aksesibilitas hingga Pemilu 2014 tetap tidak lepas dari adanya permasalahan. Seiring regulasi bagi kelompok masyarakat rentan termasuk penyandang disabilitas yang semakin baik, mahasiswa penyandang disabilitas melihat bahwa permasalahan aksesibilitas masih menjadi sebuah permasalahan klasik yang terus muncul pada setiap momen Pemilu jika kebutuhan aksesibilitas belum menjadi stereotipe positif dalam setiap kebijakan pemerintah. Pelaksanaan Pemilu dipandang masih belum berkualitas dan berhasil menyediakan perangkat yang aksesibel karena masih belum menjamin pemenuhan hak pilih penyandang disabilitas secara baik dan aksesibel. 
Mario Merly -- Aksesibilitas Pemilu 2014 Dan Implikasinya Terhadap Ketahanan Politik (Studi Tentang Persepsi Mahasiswa Penyandang Disabilitas Di Pusat Layanan Difabel UIN Sunan Kalijaga Yogyakarta)

Persepsi Mahasiswa Penyandang Disabilitas Tentang Implikasi Aksesibilitas Pemilu 2014 Terhadap Ketahanan Politik

Pertama, Implikasi Terhadap Pendidikan Politik. Persepsi mahasiswa penyandang disabilitas jika merujuk pada konsep sikap politik Sudijono Sastroadmojo (1995: 4), mengindikasikan secara sikap politik informan mahasiswa penyandang disabilitas telah mampu melakukan penilaian-penilaian politik dengan implementasi perilakuperilaku yang berbeda. Hal ini dipengaruhi oleh sikap pribadi mahasiswa penyandang disabilitas sebagai langkah pembuktian kepada masyarakat yang saat sekarang ini masih saja mendikotomikan penyandang disabilitas sebagai masyarakat kelas dua. Menurut mahasiswa penyandang disabilitas, pendidikan politik harus wajib dimiliki sebagai upaya dalam menepis paradigma medis kecacatan atau paradigma pengampuan; paradigma yang tetap selalu akan menganggap bahwa penyandang disabilitas tidak mampu. Di sisi lain, terbentuknya pendidikan politik yang baik juga dipengaruhi oleh keaktifan para mahasiswa penyandang disabilitas pada beberapa organisasi-organisasi sosial penyandang disabilitas yang justru mampu mendukung terbentuknya pendidikan politik. Mahasiswa penyandang disabilitas memandang bahwa gerakan penyandang disabilitas adalah gerakan dari bawah ke atas, artinya ada masalah dulu yang berkembang liar kemudian ada identifikasi dan baru kemudian disampaikan ke pemerintah. Berdasarkan hal itu menurut mahasiswa penyandang disabilitas untuk bisa melakukan identifikasi maupun sampai ke pemerintah tanpa adanya sebuah bekal sikap dan pengetahuan politik yang baik maka sangat sulit bagi penyandang disabilitas sendiri untuk mampu menyelesaikan masalahmasalah yang dihadapinya.

Terkait kesadaran partisipasi politik, mengindikasikan bahwa partisipasi politik bisa diklasifikasikan berdasarkan jenis disabilitasnya. Mahasiswa penyandang tunanetra dan tunadaksa telah memiliki partisipasi politik yang baik dalam Pemilu 2014 walau dilakukan dengan keterbatasan penilaian terhadap kandidat calon peserta Pemilu, sedangkan mahasiswa penyandang tunarungu-wicara masih belum baik menaruh perhatiannya dalam berpartisipasi karena masih memiliki hambatan terhadap sikap, fisik, dan informasi. Kesadaran partisipasi politik para informan penelitian dalam Pemilu apabila merujuk pada konsep partisipasi politik menurut Paigie (dalam Surbakti, Ramlan. 1992: 144), menunjukkan bahwa partisipasi mahasiswa penyandang tunarungu-wicara termasuk pada kelompok pasif-tertekan dan partisipasi mahasiswa penyandang tunanetra dan tunadaksa termasuk pada kelompok partisipasi militan-radikal, artinya partisipasi yang memiliki kesadaran politik tinggi tetapi kepercayaan terhadap pemerintah sangat rendah.

Terbentuknya pendidikan politik mahasiswa penyandang disabilitas tentunya akan mempengaruhi ketahanan politik, karena ketika sikap politik kalangan termarjinalkan seperti penyandang disabilitas terwujud, maka penyandang disabilitas tentunya akan mampu sadar dan paham dalam mengetahui hak-haknya. Implikasi bagi ketahanan politik sangat rentan terjadi ketika aksesibilitas tetap menjadi persoalan dan tidak menjadi perhatian khusus pemerintah, karena jika tidak maka sangat mungkin menimbulkan 
tekanan-tekanan berupa demontrasi, protes, dan huru-hara. Jika dipandang dari sudut usia yang tergolong muda, kekecewaan mahasiswa penyandang disabilitas berdasarkan persepsi yang disampaikan bisa melahirkan sikap apatis terhadap setiap inisiatif kebijakan yang dibuat oleh pemerintah ke depannya. Jika kondisi ini tidak ditanggulangi dan digunakan sebagai manuver politik rezim oposisi pemerintah, maka berdampak pada lemahnya integritas pemerintah dalam menjalani fungsi dan perannya kepada masyarakat. Hal tersebut bukan sesuatu yang diharapkan dalam mewujudkan ketahanan politik.

Kedua, Implikasi Terhadap Pelaksanaan Pemilu. Persepsi mahasiswa penyandang disabilitas juga berimplikasi terhadap lemahnya prinsip utama Pemilu, yakni asasasas Luber Jurdil. Pelanggaran mengenai prinsip-prinsip Pemilu justru sangat rentan dihadapi oleh pemilih penyandang disabilitas, karena salah satu faktor penyebabnya menurut mahasiswa penyandang disabilitas adalah sering diabaikannya formulir C3 atau formulir yang menjamin kerahasiaan pilihan seorang penyandang disabilitas oleh pendamping, terutama oleh petugas KPPS. Pengabaian ini terjadi dengan berbagai alasan, dua di antaranya karena memang petugas KPPS mengabaikannya baik secara sengaja maupun tidak sengaja, maupun karena si petugas tak peka terhadap hak-hak penyandang disabilitas.

Lebih lanjut, proses mekanisme yang tidak sesuai aturan ini sangat rentan dihadapi oleh kalangan penyandang disabilitas. Gagalnya implementasi dalam menjaga prinsip-prinsip Pemilu agar bisa dilaksanakan secara Luber Jurdil bagi penyandang disabilitas tentunya dapat menimbulkan keresahan. Akibatnya mudah untuk mengundang intervensi politik yang tidak sehat dan bisa berujung pada intimidasi pemilih, mengingat para penyandang disabilitas sangatlah rentan dijadikan sasaran mobilisasi suara untuk kepentingan golongangolongan tertentu. Tentunya hal ini juga dapat mengancam ketahanan politik karena Pemilu tidak lagi menjadi tumpuan dari kedaulatan rakyat namun berasal dari kepentingan politik tertentu. Implikasi terhadap hal ini kemudian bisa mempengaruhi peran serta dan partisipasi politik penyandang disabilitas dalam Pemilu dan kegiatan-kegiatan politik lainnya. Pemilu yang diselenggarakan secara tidak Luber Jurdil dapat mengakibatkan konflik yang terjadi dalam masyarakat, khususnya mengenai hak kebebasan dan hak kerahasiaan seorang pemilih. Oleh sebab itu, penyelenggaraan Pemilu yang Luber Jurdil semakin menjadi urgensi mengingat potensi konflik masyarakat sangatlah besar.

Pemilu sebagai cerminan proses demokrasi, menurut persepsi mahasiswa juga belum dikatakan berhasil dan berkualitas dalam mengakomodir kepentingan politik para penyandang disabilitas. Sehubungan dengan hal itu Afan Gaffar (1999: 7) menyoroti ciri penting ada tidaknya demokrasi, yaitu salah satunya tanpa terkecuali adalah setiap warga dapat menikmati hak-hak dasar mereka secara bebas. Pendapat Afan Gaffar di atas tidak sejalan dengan esensi demokratisasi dalam Pemilu bagi kalangan penyandang disabilitas berdasarkan hasil persepsi mahasiswa. Hal ini dipengaruhi karena menurut mahasiswa, penyandang disabilitas masih sangat minim untuk menikmati hak-hak dasar mereka secara bebas. Pemilu tidak menyediakan perangkat yang bisa membuat para penyandang disabilitas bisa memenuhi hak politiknya secara bebas dan rahasia. Tentunya dalam sebuah Pemilu 
Mario Merly -- Aksesibilitas Pemilu 2014 Dan Implikasinya Terhadap Ketahanan Politik (Studi Tentang Persepsi Mahasiswa Penyandang Disabilitas Di Pusat Layanan Difabel UIN Sunan Kalijaga Yogyakarta)

yang berkualitas mampu mengakomodir kebutuhan akses tanpa adanya diskriminasi. Pemilu sebagai cerminan proses demokrasi dinilai masih belum menegakkan kesetaraan hak antar setiap warga negara.

Berdasarkan hasil persepsi mahasiswa penyandang disabilitas, esensi proses demokrasi yang dicirikan oleh Huntington (dalam Z.A. Maulani, 1996: 31) yaitu hadirnya partisipasi masyarakat belum juga bisa dikatakan berhasil. Mahasiswa penyandang disabilitas memandang aksesibilitas belum menjadi faktor penting dalam memupuk jumlah partisipan penyandang disabilitas, bukan hanya dengan tiadanya ruang komunikasi, melainkan juga kelemahan dalam bentuk peningkatan kapasitas dan sumber daya yang dilakukan. Hal ini terjadi karena rendahnya kesadaran kolektif pemerintah akan kesetaraan penyandang disabilitas. Pemilu diselenggarakan tanpa mempertimbangkan pemahaman terhadap isu kebutuhan penyandang disabilitas, sehingga bisa berimbas pada sikap penentangan dan penolakan penyandang disabilitas terhadap masalah kenegaraan. Hal ini tentunya tidak diharapkan dalam usaha mewujudkan ketahanan politik jika esensi proses demokrasi belum menjamin keberhasilan pelaksanaan Pemilu itu sendiri.

Keberhasilan demokrasi dapat terlihat dari seberapa baiknya keberhasilan Pemilu sebagai representasi proses menuju kedaulatan rakyat. Kesetaraan menjadi unsur penting dalam sistem demokrasi. Namun pada prakteknya, tidak serta merta kesetaraan politik bisa terpenuhi di negara yang menganut sistem demokrasi, termasuk di Indonesia. Kesetaraan politik kenyataannya masih harus diperjuangkan. Salah satunya kesetaraan bagi kalangan penyandang disabilitas yang hingga kini dikatakan belum bisa dinikmati secara utuh dalam kehidupan berdemokrasi. Permasalahan aksesibilitas dalam upaya mempunyai kehidupan dan penghidupan yang baik bagi para penyandang disabilitas kerap dihadapi karena tidak ada perwakilan yang mampu merealisasikan aspirasi penyandang disabilitas di pemerintahan. Tentunya kebijakan mengenai aksesibilitas dibuat oleh orang-orang yang justru bukan penyandang disabilitas, sehingga perlu ada keterlibatan langsung melalui sistem perwakilan termasuk penyandang disabilitas untuk bisa turut terlibat dalam proses yang berkenaan dengan pembuatan kebijakan sekaligus dalam menyampaikan aspirasi mengenai kebutuhannya sendiri kepada pemerintah berdasarkan sistem perwakilan utusan golongan.

Menurut peneliti, lemahnya implementasi dalam membuka ruang kesetaraan yang sama ini tidak lepas dari proses rekrutmen politik yang pada saat sekarang justru semuanya harus dipilih. Ketika semua proses rekrutmen politik harus melalui Pemilu dan di sisi lain ruang kesetaraan terhadap hak politik para kalangan penyandang disabilitas justru menjadi kendala, alhasil kondisi ini yang memungkinkan sangat jarang keterwakilan para penyandang disabilitas di kursi politik. Apabila tidak adanya keterwakilan dari kalangan-kalangan marjinal termasuk penyandang disabilitas maka tentunya identifikasi kebutuhan serta permasalahan yang dihadapi akan semakin kian sulit untuk diperhatikan karena tidak adanya keterwakilan di kursi pemerintahan.

Menurut Afan Gaffar (1999: 281), kedaulatan ada di tangan rakyat artinya, rakyat pada dasarnya memiliki kekuasaan dalam berkehidupan bernegara. Tetapi, karena rakyat merupakan entitas yang sangat kompleks mengingat jumlahnya yang sangat besar dan variasi pengelompokannya sangat rumit karena 
berhimpitan segala macam elemen seperti agama, etnisitas, kelas sosial, asal-usul, dan lain sebagainya, maka tentu saja kedaulatan rakyat tidak secara langsung dilaksanakan sendiri oleh rakyat. Kedaulatan dilakukan melalui sistem perwakilan. Memahami pernyataan ini, peneliti mengasumsikan bahwa sistem perwakilan dari golongan-golongan masyarakat termasuk masyarakat marjinal seperti penyandang disabilitas perlu diberikan pola rekrutmen yang sama sebagai langkah konkrit menjunjung keterwakilan suara dalam wadah kedaulatan rakyat.

Namun sistem rekrutmen yang dijalankan pada sistem politik dalam negeri sekarang justru hanya terjebak pada redaksional undangundang yang mengamanatkan demokrasi semu, sehingga segala macam proses rekrutmen politik harus dijalankan dengan cara memilih. Menurut peneliti, esensi demokrasi justru tidak harus terjebak dengan cara semua harus dipilih, namun lebih kepada semua harus terwakili. Menurut Guru Besar Hukum Tata Negara Universitas Indonesia Prof. Dr. Jimly Asshiddiqie (sumber: http://perpustakaan. bappenas.go.id/) bahwa pemilihan adalah prosedur rekrutmen, tetapi prinsip semua harus terwakili itu lebih hakiki.

Pernyataan demikian apabila dimaknai dari penjelasan pasal 2 ayat (1) UUD 1945 (sebelum amandemen) sudah mampu mengakomodir kepentingan keterwakilan politik dari kalangan-kalangan marjinal misalnya, termasuk penyandang disabilitas. Pada pasal ini menyatakan "Majelis Permusyawaratan Rakyat terdiri atas anggotaanggota Dewan Perwakilan Rakyat, ditambah dengan utusan-utusan dari daerah-daerah dan golongan-golongan, menurut aturan yang ditetapkan dengan undang-undang”. Utusan golongan diasumsikan sebagai perwakilan golongan, adat maupun agama, sedangkan secara substansi, utusan golongan merupakan wadah orang-orang arif atau kader-kader terbaik bangsa yang karena keteguhannya memegang prinsip tidak menerjunkan diri dalam urusan dunia yang kotor misalnya perebutan jabatan walaupun keberadaanya diperlukan oleh negara, seperti para ulama, tokoh adat, tokoh pemuda, tokoh pendidikan, dan lain-lain. Selain peran penyeimbang, keberadaan mereka juga menjadi kanal (saluran) aspirasi bagi kelompok-kelompok yang tidak terwakili melalui rekruitmen politik formal (sumber: http://soeharto.co/konsepsiperadaban-pancasila-5).

Namun pada UUD 1945 (amandemen ke-4), pasal 2 ayat (1) UUD 1945 mengalami perubahan redaksional yakni utusan golongan dihapus. Anggota MPR terdiri dari DPR dan DPD yang semuanya direkrut melalui Pemilu terbuka. Pengamalan pasal 2 ayat (1) UUD 1945 (amandemen ke-4) justru menurut peneliti akan sangat mereduksi kepentingankepentingan dari kalangan marjinal seperti penyandang disabilitas. Pola rekrutmen politik hanya berlandaskan pada keterlibatan para elitelit di partai politik saja. Wacana keterwakilan kepentingan golongan harus berbenturan dengan kepentingan partai politik, sehingga proses menuju demokrasi harus terhambat dengan kepentingan partai politik dan bukan kepentingan rakyat sendiri.

Penghapusan utusan golongan peneliti asumsikan sebagai langkah partai politik untuk mengeleminasi institusi atau golongan di luar partai politik. Semua partai politik ingin mengklaim dirinya sebagai satusatunya aktor penentu kebijakan kenegaraan. Tentunya dalam sebuah negara demokrasi, 
Mario Merly -- Aksesibilitas Pemilu 2014 Dan Implikasinya Terhadap Ketahanan Politik (Studi Tentang Persepsi Mahasiswa Penyandang Disabilitas Di Pusat Layanan Difabel UIN Sunan Kalijaga Yogyakarta)

partai politik tidak lantas hanya sebagai tonggak dalam menaungi kepentingan rakyat. Stabilitas politik dalam negeri akan terjaga dengan baik ketika setiap elemen baik partai politik dan setiap golongan masyarakat dapat mengakomodir kepentingannya dengan baik dalam pemerintahan. Keterwakilan merupakan unsur penting dalam rangka menjaga keberlangsungan stabilitas politik. Akses kehidupan politik para penyandang disabilitas dan kalangan marjinal lainnya saat sekarang hanya bergantung pada elit-elit partai politik yang menurut hasil persepsi informan dalam penelitian ini belum cukup mampu menaungi aspirasi kalangan penyandang disabilitas dan kelompok marjinal lainnya.

Aspirasi menjadi terbengkalai ketika peran dan fungsi elit partai pun gagal dalam mengamalkannya, namun jika implementasi sistem perwakilan politik utusan golongan diadakan kembali maka justru membuka ruang politik yang baik bagi para penyandang disabilitas untuk bisa secara mandiri menyuarakan aspirasinya secara baik dan mandiri kepada utusan golongan yang mewakilinya. Keadaan ini menurut peneliti mampu dalam menjaga stabilitas politik dalam negeri sebagai rangkaian menjaga ketahanan politik karena sistem perwakilan utusan golongan telah mampu mengisi ruang kosong suara publik yang dalam kondisi sekarang masih saja dikalahkan dengan suara dari kepentingan elit partai politik.

Ketiga, Implikasi Terhadap Legitimasi Pemerintah. Permasalahan tentang ketiadaan aspirasi golongan kemudian justru mempengaruhi persepsi mahasiswa penyandang disabilitas dalam penelitian ini terhadap legitimasi pemerintah. Kekecewaan dan ketidakpercayaan mahasiswa penyandang disabilitas berdasarkan hasil persepsi yang disampaikan terhadap legitimasi pemerintah dapat mempengaruhi stabilitas politik terutama ketahanan politik, karena stabilitas politik menuntut peran serta semua lapisan masyarakat termasuk penyandang disabilitas, tentunya dengan kesadaran pendidikan politik yang baik. Ketahanan politik akan semakin rentan dipengaruhi ketika tingkat kepercayaan masyarakat penyandang disabilitas semakin rendah kepada pemerintah.

Lemahnya integritas kinerja pemerintah berdasarkan persepsi informan penelitian juga dipicu dari persepsi mengenai aksesibilitas pelayanan publik dan kebijakan publik sebagai kebutuhan utama dari para penyandang disabilitas untuk dapat mengaktualisasikan diri dan sekaligus berpartisipasi penuh dalam aktifitas bermasyarakat belum berhasil dilaksanakan dengan baik oleh pemerintah. Ketiadaan pelayanan publik dan realisasi kebijakan publik justru menurut para informan penelitian belum sangat berpihak baik kepada para penyandang disabilitas pada umumnya, sehingga menyebabkan eksklusivitas bagi para penyandang disabilitas di lingkungan masyarakatnya karena tidak adanya ruang publik yang memungkinkan mereka untuk dapat menjalankan aktivitas secara wajar sebagaimana anggota masyarakat lain dan tidak terbukanya ruang kesetaraan yang sama dalam usaha peningkatan sumberdaya yang komprehensif dari program-program pemerintah sendiri.

\section{SIMPULAN}

Berdasarkan hasil pembahasan yang telah dipaparkan, penelitian ini merangkum dua kesimpulan yaitu: 
Pertama, Persepsi mahasiswa penyandang disabilitas di Pusat Layanan Difabel (PLD) UIN Sunan Kalijaga Yogyakarta yang terdiri atas 13 orang informan dalam penelitian ini, menganggap bahwa aksesibilitas Pemilu 2014 yang diperuntukkan bagi mereka masih belum dikatakan baik. Penilaian ini didasarkan pada pengalaman serta pandangan mereka secara umum tentang aksesibilitas Pemilu 2014. Informan penelitian juga masih menilai buruk implementasi perundangundangan yang secara jelas telah banyak mengatur aksesibilitas namun pijakan regulasi tidak serta merta mampu dilaksanakan baik oleh penyelenggara Pemilu untuk mendesain Pemilu yang aksesibel bagi penyandang disabilitas. Minimnya aksesibilitas bagi pemilih penyandang disabilitas tak mampu diruntuhkan walau aspek legalnya telah diatur dalam perundang-undangan, dan hambatan-hambatan inilah yang paling menggangu pemilih penyandang disabilitas yang berpotensi mereduksi keterlibatan mereka dalam Pemilu.

Kedua, Persepsi mahasiswa penyandang disabilitas berimplikasi terhadap lemahnya pelaksanaan Pemilu, yakni menjaga asas-asas Luber Jurdil dan pelaksanaan Pemilu sebagai cerminan proses demokrasi yang menurut mahasiswa juga belum dikatakan berhasil dan berkualitas dalam mengakomodir kepentingan politik para penyandang disabilitas. Hal ini terjadi karena penyelenggaraan Pemilu sendiri dilaksanakan tanpa ide-ide inovatif terkait sistem dan penyelenggaraan Pemilu yang inklusif yang dapat memastikan peningkatan partisipasi semua masyarakat termasuk penyandang disabilitas. Permasalahan yang dialami kalangan marjinal seperti penyandang disabilitas terjadi karena sangat minimnya gerakan serta perwakilan utusan golongan kalangan marjinal yang mampu mengakomodir hak-hak aksesibilitas khususnya bagi para penyandang disabilitas.

Persepsi mahasiswa penyandang disabilitas juga berimplikasi pada lemahnya legitimasi pemerintah. Kekecewaan terhadap kinerja serta pelayanan publik oleh pemerintah yang masih sangat minim menjamah ranah kepentingan kehidupan dan penghidupan para penyandang disabilitas, pelayanan dan kebijakan publik yang juga masih cenderung bias isu kesetaraan disabilitas menimbulkan implikasi sosial politik yang sangat buruk bagi kaum penyandang disabilitas. Namun hal yang patut untuk diperhatikan menurut peneliti adalah, dari segi sikap politik mahasiswa penyandang disabilitas sebagai representasi kaum muda penyandang disabilitas dikatakan telah cukup baik. Ketika kebijakan aksesibilitas tetap diabaikan terus-menerus dan tidak menjadi ajang perhatian pemerintah untuk berusaha menyediakan akses yang baik maka bisa memunculkan sikap arogansi politik mahasiswa penyandang disabilitas dan berbuah menjadi perilaku pragmatis dan pembangkangan berupa diabaikannya kewajiban atau tidak menaruh perhatian terhadap masalah kenegaraan. Pada akhirnya peran politik khususnya generasi muda mahasiswa penyandang disabilitas pun bisa menjadi rentan karena berwujud sikap kehilangan kepercayaan (public trust) terhadap pemerintah. Implikasi terhadap hal ini sangat rentan mempengaruhi ketahanan politik, karena tanpa kepercayaan publik maka kunci penting dalam membangun masyarakat yang demokratis tidak akan terwujud. 
Mario Merly -- Aksesibilitas Pemilu 2014 Dan Implikasinya Terhadap Ketahanan Politik (Studi Tentang Persepsi Mahasiswa Penyandang Disabilitas Di Pusat Layanan Difabel UIN Sunan Kalijaga Yogyakarta)

\section{DAFTAR PUSTAKA}

AGENDA. 2013. "Accessible Elections for Persons With Disabilities in Indonesia (Aksesibilitas Pemilu untuk Difabel di Indonesia)”. Jakarta: PPUA PENCA.

Budiarjo, Miriam. 1981. "Partisipasi dan Partai Politik: Sebuah Bunga Rampai”. Jakarta: PT. Gramedia.

Gaffar, Afan. 1999. Politik Indonesia; Transisi Menuju Demokrasi. Yogyakarta: Pustaka Pelajar.

Hermawan, Agus Aan. "Persepsi Pemuda Terhadap Partai Politik Nasional Peserta Pemilu 2014 Dan Implikasinya Terhadap Ketahanan Politik Wilayah (Studi Pada KNPI Provinsi Banten)”. Tesis. Ketahanan Nasional Sekolah Pascasarjana Universitas Gadjah Mada. Kartini, Kartono. 1996. "Pendidikan Politik”. Bandung: CV. Mandar Maju.

Lemhannas. 1997. Ketahanan Nasional Jakarta: PT. Balai Pustaka.

Mas'oed Mohtar. 2003. Negara, Kapital dan Demokrasi. Yogyakarta: Pustaka Pelajar.

Maulani, Z.A. 1996. Keterbukaan Informasi dan Stabilitas Politik. Yogyakarta: Gadjah Mada University Press.

Rakhmat, Jalaludin. 2003. “Psikologi Informasi”, Bandung: PT. Remaja Rosdakarya.

Salim, Ishak. 2014. Memahami Pemilihan Umum dan Gerakan Politik Kaum Difabel. Yogyakarta: SIGAB.

Sastroadmojo, Sudijono. 1995. Perilaku Politik Semarang: IKIP Semarang Press.

Soekarwo, Ariani. 2009. Buku Panduan Akses Pemilu Bagi Penyandang Disabilitas. Jakarta: PPUA PENCA.

Sunardi, 1997. Teori Ketahanan Nasional. Jakarta: Hastanas.
Surbakti, Ramlan. 1992. Memahami Ilmu Politik. Jakarta: PT. Grasindo.

Tricahyo, Ibnu. 2009. Reformasi Pemilu Menuju Pemisahan Pemilu Nasional dan Lokal. Malang: In Trans Publishing.

\section{Undang-undang:}

UU RI Nomor 39 Tahun 1999 Tentang Hak Asasi Manusia.

UU RI Nomor 19 Tahun 2011 Tentang Pengesahan Konvensi Mengenai Hakhak Penyandang Disabilitas.

\section{Internet:}

http:// perpustakaan.bappenas.go.id/. BAPPENAS. "MPR Pascaperubahan UUD 1945”. Akses 15 Juni 2015.

http://rumahopini.com/partisipasipenyandang-disabilitas-dalam-politik2014/. Thohari, Slamet. 2014. "Partisipasi Penyandang Disabilitas dalam Politik 2014”. Akses 30 November 2014.

http://www.radarjogja.co.id/blog/2014/10/18/ demo-difabel-protes-mekanisme-tescpns/. Setiaky A. Kusuma. "Demo, Difabel Protes Mekanisme Tes CPNS”. Akses 10 November 2014.

http://soeharto.co/konsepsi-peradabanpancasila-5. Rohman, Abdul. 2013. “Konsepsi Peradaban Pancasila”. Akses 15 Juni 2015.

http://www.gresnews.com/berita/ politik/1110172-penyandang-disabilitastuntut-kpu-sediakan-fasilitas-Pemiluuntuk-kaum-difabel/. "Penyandang Disabilitas Tuntut KPU Sediakan Fasilitas Pemilu untuk Kaum Difabel”. Sahid, Mungky. 2014. Akses 10 November 2014). 


\title{
EFEKTIVITAS PEMANFAATAN BIOGAS UNTUK MENUNJANG KETAHANAN ENERGI (Studi Di Desa Pendoworejo Kecamatan Girimulyo Kabupaten Kulon Progo Daerah Istimewa Yogyakarta)
}

\author{
Dyah Sri Palupi \\ Kantor Kementerian Agama Kabupaten Bantul \\ lupi_810o@yahoo.com
}

\begin{abstract}
The development of renewable energy was one of the crises of energy solutions. The purposes of the research were to analyzed the effectiveness of biogas utilization and examine the connection of that utilization with energy resilience at Pendoworejo.

The research method was qualitative descriptive analysis approach. Total amount the biodigesters were 183 units. Purposive sampling technique was used to determined the samples. The total informants were 55 people. Data collection techniques included literature studies, observation, interviews, and documents studies.

The research results were $30.26 \%$ able to used and $69.77 \%$ unable to used. The continuity of effectiveness in utilizations was for daily using in the category low (25.58\%), sometimes in using in the category very low (4.65\%) and damage in the category enough (69.77\%). The biogas utilization or function effectiveness were for cooking in the category high (86.82\%), for the generator set (3.1\%) and others (10.08\%) in the category very low. The effectiveness for providing the needs were providing all needs in the category very low (9.3\%), part of the needs in the category low (20.93\%) and not at all in the category enough (69.77\%). The effectiveness of biogas utilization at Pendoworejo village for energy resilience were at low level. The expectation in the next the Pendoworejo village would be self-supporting in energy, but the energy resources of biogas at the village had not reached more than $60 \%$ of total required energy. The effectiveness of biogas utilization at Pendoworejo village currently were not being able to supported the energy resilience yet.
\end{abstract}

Keywords: Effectiveness, Biogas, Energy Resilience.

\begin{abstract}
ABSTRAK
Pengembangan energi terbaharukan merupakan salah satu solusi krisis energi. Penelitian bertujuan untuk menganalisis tingkat efektivitas pemanfaatan biogas dan mengkaji hubungan efektivitas pemanfaatan biogas di Desa Pendoworejo dengan ketahanan energi.

Metode penelitian yaitu kualitatif dengan pendekatan analisis deskriptif. Jumlah biodigester 183 unit. Penentuan sampel dengan teknik purposive sampling. Jumlah informan 55 orang. Teknik pengumpulan data meliputi studi kepustakaan, observasi, wawancara, dan studi dokumentasi.

Hasil penelitian yaitu 30,26\% biodigester berfungsi dan 69,77\% dalam kondisi rusak. Efektivitas kontinuitas pemanfaatan dan ketersediaan biogas yakni pemanfaatan harian dalam kategori rendah (25,58\%), pemanfaatan kadang-kadang dalam kategori sangat rendah (4,65\%) dan kondisi rusak dalam kategori cukup (69,77\%). Efektivitas pemanfaatan atau fungsi yakni untuk memasak dalam kategori tinggi (86,82\%), genset (3,1\%) dan lainnya $(10,08 \%)$ dalam kategori sangat rendah. Efektivitas pemenuhan kebutuhan energi berbahan biogas yaitu memenuhi kebutuhan
\end{abstract}


Dyah Sri Palupi -- Efektivitas Pemanfaatan Biogas Untuk Menunjang Ketahanan Energi (Studi Di Desa Pendoworejo Kecamatan Girimulyo Kabupaten Kulon Progo Daerah Istimewa Yogyakarta)

dalam kategori sangat rendah (9,3\%), sebagian memenuhi kebutuhan dalam kategori rendah (20,93\%), dan tidak memenuhi kebutuhan dalam kategori cukup (69,77\%). Efektivitas pemanfaatan biogas di Desa Pendoworejo termasuk rendah. Desa Pendoworejo diharapkan menjadi Desa Mandiri Energi, namun sumber energi dari biogas belum mencapai lebih dari 60\%. Efektivitas pemanfaatan biogas di Desa Pendoworejo belum mampu menunjang ketahanan energi.

Kata kunci: Efektivitas, Biogas, Ketahanan Energi.

\section{PENGANTAR}

Setiap bangsa berusaha mendapatkan sumber energi dari dalam dan luar negeri (Dirwan, 2012). Energi fosil yang digunakan saat ini sekitar 80\% (Campbell, 1983). Energi fosil merupakan energi tidak terbaharukan. Indonesia menjadi anggota Organization for Petroleum Exporting Countries (OPEC) tahun 1962-2009. Indonesia kini menjadi importir neto (Nugroho, 2005). Pengimpor bahan bakar menunjukkan ketahanan energi Indonesia rendah (Dirwan, 2012).

Ketahanan energi merupakan kemampuan suatu negara sehingga tersedia pasokan energi yang handal, terjangkau, efisien, ramah lingkungan, dan diterima konsumen akhir (Indrawan dan Wijaya, 2011). Sumber energi tidak terbaharukan terkuras dan peningkatan kebutuhan energi menimbulkan ancaman krisis energi. Daya tahan energi Indonesia berkurang dan krisis energi mengancam. Salah satu pemecahan krisis energi yakni pengembangan energi terbaharukan.

Pemerintah mengupayakan program Desa Mandiri Energi (DME). Energi merupakan titik masuk pengembangan kegiatan ekonomi perdesaan (Prasetyo dan Hanifah, 2011). Sumber daya pertanian dan peternakan Indonesia cukup besar. Sumber daya untuk pangan dan berpotensi sebagai sumber energi dengan cara pemanfaatan kotoran ternak menjadi biogas. Nilai kalor biogas yaitu 4.800-6.700 kkal/m³ (Nurhasanah dkk., 2006). Biogas dihasilkan bakteri melalui fermentasi bahan organik dalam kondisi tanpa oksigen (Elizabeth dan Rusdiana, 2011).

Desa Pendoworejo telah mengembangkan energi alternatif biodigester sebagai penghasil biogas. Terkait dengan potensi pemanfaatan limbah peternakan untuk bahan biogas maka penelitian dengan judul "Efektivitas Pemanfaatan Biogas untuk Menunjang Ketahanan Energi (Studi Di Desa Pendoworejo Kecamatan Girimulyo Kabupaten Kulon Progo Daerah Istimewa Yogyakarta)” sangat strategis dan memberikan informasi dalam strategi pengembangan energi alternatif berbasis sumber daya lokal.

Penelitian ini memiliki beberapa tujuan yaitu: Pertama, menganalisis efektivitas pemanfaatan biogas di Desa Pendoworejo. Kedua, mengkaji hubungan efektivitas pemanfaatan biogas di Desa Pendoworejo dengan ketahanan energi.

Metode penelitian yang digunakan yakni kualitatif dengan pendekatan analisis deskriptif. Studi kepustakaan dilakukan di Yogyakarta. Penelitian lapangan dilaksanakan di Desa Pendoworejo dan instansi terkait di Wates dan Pengasih pada tanggal 1 Desember 2014 hingga 27 Februari 2015. Populasi berjumlah 183 orang sesuai dengan jumlah peternak yang mempunyai biodigester. Sampel ditentukan dengan teknik non probability sampling secara khusus yaitu purposive sampling.

Sampel yakni informan yang mengetahui pemanfaatan biogas dan memiliki biodigester. 
Jumlah informan 55 orang yakni peternak, pengurus kelompok tani atau gabungan kelompok tani (gapoktan), tokoh masyarakat (tomas), penyuluh, kepala desa, kepala dukuh, dan instansi terkait. Informan peternak yaitu 43 orang yaitu peternak murni dan peternak yang berperan ganda sebagai pengurus kelompok tani, pengurus gapoktan, tokoh masyarakat, kepala dukuh atau kepala desa.

Teknik pengumpulan data yang digunakan yakni: (1) Studi kepustakaan; (2) Observasi non partisipan; (3) Wawancara perseorangan (in depth interview) dan kelompok (Focus Group Discussion); (4) Studi dokumentasi dari Kantor Lingkungan Hidup, Dinas Kelautan Perikanan dan Peternakan, Dinas Perindustrian Perdagangan dan Energi Sumber Daya Mineral, dan Kantor Ketahanan Pangan dan Penyuluhan Pertanian Perikanan Kehutanan, dan pencatatan Desa Pendoworejo.
Data dianalisis dengan teknik persentase. Rumus efektivitas yaitu: $\frac{\text { Hasil nyata }}{\text { Sasaran }}$ 100\% (PIMLPPM, 1997). Interpretasi nilai berdasarkan tabel yang disusun oleh Arikunto (1998). Tabel interpretasi nilai dapat dilihat dalam tabel 1.

Tabel 1. Interpretasi nilai (\%)

\begin{tabular}{cc}
\hline Besar nilai efektivitas (\%) & Nilai interpretasi efektivitas \\
\hline $80-100$ & Tinggi \\
$60-79,9$ & Cukup \\
$40-59,9$ & Agak rendah \\
$20-39,9$ & Rendah \\
$0-19,9$ & Sangat rendah \\
\hline
\end{tabular}

Sumber: Arikunto, 1998.

Data dicek dan ricek dengan triangulasi. Triangulasi metode yakni membandingkan beberapa metode yang digunakan yaitu studi kepustakaan, observasi, wawancara, dan studi dokumentasi. Triangulasi sumber berupa perbandingan data yang berasal dari peternak,

Tabel 2. Jumlah instalasi biogas di Kabupaten Kulon Progo 2008-2014 (unit)

\begin{tabular}{|c|c|c|c|c|c|c|c|c|c|c|c|c|c|c|c|}
\hline \multirow{2}{*}{ No } & \multirow{2}{*}{ Instansi } & \multicolumn{7}{|c|}{ Pembangunan instalasi biogas } & \multicolumn{7}{|c|}{ Total instalasi biogas per tahun } \\
\hline & & 2008 & 2009 & 2010 & 2011 & 2012 & 2013 & 2014 & 2008 & 2009 & 2010 & 2011 & 2012 & 2013 & 2014 \\
\hline 1. & $\begin{array}{l}\text { Kantor } \\
\text { Lingkungan } \\
\text { Hidup (kab) }\end{array}$ & 28 & 48 & 44 & 21 & 26 & 30 & 11 & 28 & 76 & 120 & 141 & 167 & 197 & 208 \\
\hline 2. & $\begin{array}{l}\text { Kementerian } \\
\text { Lingkungan } \\
\text { Hidup (pusat) } \\
\end{array}$ & - & - & 167 & - & - & - & - & - & - & 167 & 167 & 167 & 167 & 167 \\
\hline 3. & $\begin{array}{l}\text { Diskepenak } \\
\text { (kab) }\end{array}$ & $87 *)$ & 5 & 9 & - & - & - & - & 87 & 92 & 101 & 101 & 101 & 101 & 101 \\
\hline 4. & $\begin{array}{l}\text { Dinas } \\
\text { Perindustrian } \\
\text { Perdagangan dan } \\
\text { ESDM (kab) }\end{array}$ & - & - & - & - & 30 & 23 & 64 & - & - & - & - & 30 & 53 & 117 \\
\hline 5. & $\begin{array}{l}\text { Dinas Pekerjaan } \\
\text { Umum dan } \\
\text { ESDM (provinsi) }\end{array}$ & - & $1 * *)$ & - & - & - & 5 & - & - & 1 & 1 & 1 & 6 & 6 & 6 \\
\hline 6. & $\begin{array}{l}\text { Kementerian } \\
\text { ESDM (pusat) }\end{array}$ & - & - & - & - & 17 & 37 & - & - & - & - & - & 17 & 54 & 54 \\
\hline 7. & $\begin{array}{l}\text { Instansi provinsi } \\
* *)\end{array}$ & - & - & 4 & - & - & - & - & - & - & 4 & 4 & 4 & 4 & 4 \\
\hline & Jumlah & 115 & 54 & 224 & 21 & 73 & 95 & 75 & 115 & 169 & 393 & 414 & 487 & 582 & 657 \\
\hline
\end{tabular}

Keterangan: kab=kabupaten; *) Total unit instalasi biogas tahun 2004-2008;

**) Hasil wawancara dengan peternak, 2014.

Sumber: Dinas Kelautan Perikanan dan Peternakan, 2014; Dinas Perindustrian Perdagangan dan ESDM 2014; Kantor Lingkungan Hidup, 2014; wawancara dengan peternak, 2014. 
kelompok tani, gabungan kelompok tani, desa, dan instansi terkait.

\section{PEMBAHASAN}

\section{Instalasi Biogas di Desa Pendoworejo}

Kantor Lingkungan Hidup, Dinas Kelautan Perikanan dan Peternakan (Diskepenak), dan Dinas Perindustrian Perdagangan dan Energi Sumber Daya Mineral (ESDM) membangun instalasi biogas di Kabupaten Kulon Progo. Selain itu instansi pusat dan provinsi juga terlibat. Jumlah instalasi biogas di Kabupaten Kulon Progo 2008-2014 (unit) dapat dilihat dalam tabel 2.

Jumlah instalasi biogas terbanyak pada tahun 2014 dalam tabel 2 bersumber dari Kantor Lingkungan Hidup kabupaten (208 unit). Jumlah instalasi biogas pada tahun 2013 sebanyak 582 unit, sedangkan Idhiar Nugroho dari Dinas Perindustrian Perdagangan dan ESDM menyatakan 752 unit. Instalasi biogas sebanyak 170 unit tidak diketahui sumbernya. Peneliti kesulitan mendapat jumlah dan sumber instalasi biogas dengan tepat. Instansi hanya memiliki data jumlah biodigester yang dibangun dan tembusan dari instansi pusat atau provinsi. Perubahan staf yang menangani bantuan biodigester menyebabkan informasi yang diperoleh terbatas. Informasi lain diperoleh saat wawancara dengan peternak.

Bantuan biodigester di Desa Pendoworejo dikelompokkan menjadi tiga yaitu dari
Kementerian Lingkungan Hidup, Diskepenak, dan instansi lain. Sumber bantuan biodigester, jumlah informan peternak, dan persentase di Desa Pendoworejo dapat dilihat dalam tabel 3.

Jumlah bantuan biodigester di Desa Pendoworejo di dalam tabel 3 meningkat dari tahun 2004-2010. Biodigester terbanyak bantuan dari Kementerian Lingkungan Hidup (167 unit). Total bantuan biodigester sampai dengan tahun 2010 sebanyak 183 unit. Jumlah informan peternak yaitu 43 orang $(23,5 \%)$.

\section{Penilaian Efektivitas Pemanfaatan Biogas di Desa Pendoworejo}

Biogas dikatakan efektif jika biodigester berfungsi baik, demikian juga sebaliknya. PernyataantersebuthasilFoccus GroupDiscussion (FGD). Kriteria efektivitas pemanfaatan biogas di Desa Pendoworejo dilihat dari tiga sudut pandang yaitu kontinuitas ketersediaan dan pemanfaatan biogas, pemanfaatan atau fungsi biogas, dan pemenuhan kebutuhan energi berbahan biogas.

\section{Efektivitas Dilihat dari Kontinuitas Ketersediaan dan Pemanfaatan Biogas}

Efektivitas pertama dilihat dari kontinuitas ketersediaan dan pemanfaatan biogas. Kriteria yang digunakan yakni harian, kadang-kadang dan kondisi rusak. Kontinuitas ketersediaan dan pemanfaatan biogas terdapat dalam tabel 4.

Tabel 3. Sumber bantuan biodigester, jumlah informan peternak, dan persentase di Desa Pendoworejo

\begin{tabular}{|c|c|c|c|c|c|c|c|c|c|c|c|}
\hline \multirow[t]{2}{*}{ No } & \multirow{2}{*}{$\begin{array}{l}\text { Sumber bantuan } \\
\text { biodigester }\end{array}$} & \multicolumn{4}{|c|}{ Pembangunan biodigester } & \multicolumn{4}{|c|}{ Total biodigester per tahun } & \multirow{2}{*}{$\begin{array}{l}\text { Jumlah informan } \\
\text { peternak }\end{array}$} & \multirow{2}{*}{$\begin{array}{l}\text { Persentase } \\
\text { (\%) }\end{array}$} \\
\hline & & 2004 & 2008 & 2009 & 2010 & 2004 & 2008 & 2009 & 2010 & & \\
\hline 1 & $\begin{array}{l}\text { Kementerian } \\
\text { Lingkungan Hidup }\end{array}$ & - & - & - & 167 & - & - & - & 167 & 34 & 20,36 \\
\hline 2 & Diskepenak & 2 & 1 & 3 & 4 & 2 & 3 & 6 & 10 & 5 & 50 \\
\hline 3 & Instansi lain & - & - & 1 & 5 & - & - & 1 & 6 & 4 & 66,67 \\
\hline & Total & 2 & 1 & 4 & 176 & 2 & 3 & 7 & 183 & 43 & 23,5 \\
\hline
\end{tabular}

Sumber: Pencatatan Desa Pendoworejo, 2014; Analisis data primer, 2015. 
Jurnal Ketahanan Nasional, Vol. 21, No. 2, Agustus 2015: 78-88

Tabel 4. Kontinuitas ketersediaan dan pemanfaatan biogas

\begin{tabular}{|c|c|c|c|c|c|c|c|c|c|}
\hline \multirow[b]{2}{*}{ No } & \multirow{2}{*}{$\begin{array}{c}\text { Sumber } \\
\text { bantuan } \\
\text { biodigester }\end{array}$} & \multicolumn{3}{|c|}{ Kontinuitas (orang) } & \multirow[b]{2}{*}{ Total } & \multicolumn{3}{|c|}{ Persentase (\%) } & \multirow[b]{2}{*}{ Total } \\
\hline & & Harian & Kadang-kadang & Rusak & & Harian & Kadang-kadang & Rusak & \\
\hline 1 & $\begin{array}{l}\text { Kementerian } \\
\text { Lingkungan Hidup }\end{array}$ & 6 & 1 & 27 & 34 & 17,65 & 2,94 & 79,41 & 100 \\
\hline 2 & Diskepenak & 3 & 1 & 1 & 5 & 60 & 20 & 20 & 100 \\
\hline 3 & Instansi lain & 2 & - & 2 & 4 & 50 & - & 50 & 100 \\
\hline & Total & 11 & 2 & 30 & 43 & 25,58 & 4,65 & 69,77 & 100 \\
\hline
\end{tabular}

Sumber: Analisis data primer, 2015.

Nilai interpretasi efektivitas didasarkan pada tabel dari Arikunto (1998). Kontinuitas ketersediaan dan pemanfaatan biogas bersumber dari bantuan Kementerian Lingkungan Hidup yakni pemanfaatan harian dalam kategori sangat rendah $(17,65 \%)$, kadang-kadang dalam kategori sangat rendah (2,94\%), dan kondisi rusak dalam kategori cukup (79,41\%). Kontinuitas ketersediaan dan pemanfaatan biogas bersumber dari Diskepenak yaitu pemanfaatan harian tergolong cukup (60\%), kadang-kadang tergolong rendah (20\%) dan kondisi rusak tergolong rendah (20\%). Kontinuitas ketersediaan dan pemanfaatan biogas bantuan dari instansi lain yaitu pemanfaatan harian termasuk agak rendah (50\%) dan kondisi rusak termasuk agak rendah (50\%).

Total kontinuitas ketersediaan dan pemanfaatan biogas baik harian dan kadangkadang dalam kategori rendah (30,26\%). Jika ketiga instansi dibandingkan maka kontinuitas ketersediaan dan pemanfaatan biogas harian yang tertinggi yaitu bersumber dari Diskepenak, instansi lain dan Kementerian Lingkungan Hidup. Kontinuitas ketersediaan dan pemanfaatan biogas kadang-kadang yaitu bersumber dari Diskepenak selanjutnya instansi lain. Kontinuitas ketersediaan dan pemanfaatan biogas dipengaruhi beberapa faktor yaitu kapasitas, konstruksi biodigester, pengisian, kondisi bak dan saluran pembuangan.
Kapasitas biodigester bantuan dari Kementerian Lingkungan Hidup yakni 4,5 $\mathrm{m}^{3}$, Diskepenak yaitu $9 \mathrm{~m}^{3}$, dan instansi lain antara $6 \mathrm{~m}^{3}-12 \mathrm{~m}^{3}$. Kubah biodigester bantuan dari Kementerian Lingkungan Hidup bocor di sambungan. Para peserta FGD menyatakan bahwa campuran biodigester bantuan dari Kementerian Lingkungan Hidup kurang memenuhi standar. Perbandingan semen:pasir yang baik yaitu 1:3. Hal ini sesuai dengan pendapat Elizabeth dan Rusdiana (2011) yang menyatakan bahwa kapasitas dan konstruksi biodigester menentukan kuantitas produksi biogas. Digester harus anaerob. Apabila digester bocor maka volumebiogas tertampung berkurang dan api yang dihasilkan kecil.

Pengisian biodigester yang baik dilakukan setiap hari, namun peternak di Desa Pendoworejo mengisi 2-3 hari sekali. Pengisian tergantung kesibukan, saat panen pengisian biodigester seminggu sekali. Jika biodigester tidak diisi akan macet. Faktor yang lain yang berpengaruh yaitu kondisi bak penuh sehingga produksi biogas berkurang. Saluran pembuangan yang tidak memadai juga membuat kontinuitas ketersediaan dan pemanfaatan biogas tidak sesuai harapan.

\section{Efektivitas Dilihat dari Pemanfaatan atau Fungsi Biogas}

Efektivitas kedua dilihat dari pemanfaatan atau fungsi biogas. Kriteria yang dipakai 
yaitu untuk memasak, genset dan lainnya. Pemanfaatan lainnya yakni hasil samping berupa limbah biogas yang digunakan untuk pupuk tanaman. Pemanfaatan atau fungsi biogas dapat dilihat dalam tabel 5 .

Biodigester bersumber dari bantuan Kementerian Lingkungan Hidup untuk memasak dalam kategori tinggi (91\%), sedangkan lainnya dalam kategori sangat rendah (9\%). Biodigester bantuan Diskepenak untuk memasak tergolong tinggi (80\%), sedangkan lainnya tergolong rendah (20\%). Biodigester bantuan dari instansi lain untuk memasak termasuk agak rendah (58,33\%), genset termasuk rendah (33,3\%), sedangkan lainnya termasuk sangat rendah (8,33\%).

Total pemanfaatan biogas yaitu untuk memasak dalam kategori tinggi (86,82\%). Pemanfaatan genset $(3,1 \%)$ dan lainnya (10,08\%) dalam kategori sangat rendah. Jika tiga instansi dibandingkan maka biodigester yang dimanfaatkan untuk memasak terbanyak yakni bersumber dari bantuan Kementerian
Lingkungan Hidup, kemudian bantuan Diskepenak dan instansi lain. Genset hanya dimanfaatkan oleh informan yang mendapat bantuan dari instansi lain. Pemanfaaatan lainnya yang terbanyak yakni bersumber dari bantuan Diskepenak, Kementerian Lingkungan Hidup, kemudian instansi lain.

Pemanfaatan biogas tergantung komponen bantuan yang diberikan. Komponen bantuan dari Kementerian Lingkungan Hidup dan Diskepenak yaitu untuk memasak. Biodigester bantuan dari instansi lain untuk memasak dan genset. Biodigester Muh. Paino berasal dari bantuan Diskepenak untuk memasak dengan kapasitas $9 \mathrm{~m}^{3}$. Biodigester tersebut pernah dipakai Lembaga Ilmu Pengetahuan Indonesia (LIPI) Gunung Kidul untuk genset dan berfungsi. Genset dibawa sendiri oleh LIPI.

\section{Efektivitas Dilihat dari Pemenuhan Kebutuhan Energi Berbahan Biogas}

Efektivitas ketiga dilihat dari pemenuhan kebutuhan energi berbahan biogas. Kriteria

Tabel 5. Pemanfaatan atau fungsi biogas

\begin{tabular}{|c|c|c|c|c|c|c|c|c|c|}
\hline \multirow{2}{*}{ No } & \multirow{2}{*}{$\begin{array}{c}\text { Sumber bantuan } \\
\text { biodigester }\end{array}$} & \multicolumn{3}{|c|}{ Pemanfaatan atau fungsi (orang) } & \multirow{2}{*}{ Total } & \multicolumn{3}{|c|}{ Persentase (\%) } & \multirow{2}{*}{ Total } \\
\hline & & Memasak & Genset & Lainnya & & Memasak & Genset & Lainnya & \\
\hline 1 & $\begin{array}{l}\text { Kementerian Lingkungan } \\
\text { Hidup }\end{array}$ & 31 & - & 3 & 34 & 91 & - & 9 & 100 \\
\hline 2 & Diskepenak & 4 & - & 1 & 5 & 80 & - & 20 & 100 \\
\hline \multirow[t]{2}{*}{3} & Instansi lain & 2,33 & 1,33 & 0,33 & 4 & 58,33 & 33,33 & 8,33 & 100 \\
\hline & Total & 37,33 & 1,33 & 4,33 & 43 & 86,82 & 3,1 & 10,08 & 100 \\
\hline
\end{tabular}

Sumber: Analisis data primer, 2015.

Tabel 6. Pemenuhan kebutuhan energi berbahan biogas

\begin{tabular}{|c|c|c|c|c|c|c|c|c|c|}
\hline \multirow[b]{2}{*}{ No } & \multirow{2}{*}{$\begin{array}{c}\text { Sumber } \\
\text { bantuan biodigester }\end{array}$} & \multicolumn{3}{|c|}{ Pemenuhan kebutuhan (orang) } & \multirow[b]{2}{*}{ Total } & \multicolumn{3}{|c|}{ Persentase (\%) } & \multirow[b]{2}{*}{ Total } \\
\hline & & Memenuhi & Sebagian & $\begin{array}{c}\text { Tidak } \\
\text { memenuhi }\end{array}$ & & Memenuhi & Sebagian & $\begin{array}{c}\text { Tidak } \\
\text { memenuhi }\end{array}$ & \\
\hline 1 & $\begin{array}{l}\text { Kementerian } \\
\text { Lingkungan Hidup }\end{array}$ & - & 7 & 27 & 34 & - & 20,59 & 79,41 & 100 \\
\hline 2 & Diskepenak & 2 & 2 & 1 & 5 & 40 & 40 & 20 & 100 \\
\hline 3 & Instansi lain & 2 & - & 2 & 4 & 50 & - & 50 & 100 \\
\hline & Total & 4 & 9 & 30 & 43 & 9,3 & 20,93 & 69,77 & 100 \\
\hline
\end{tabular}

Sumber: Analisis data primer, 2015. 
pemenuhan kebutuhan energi berbahan biogas yaitu memenuhi, sebagian atau tidak memenuhi. Pemenuhan kebutuhan energi berbahan biogas dapat terdapat tabel 6 .

Pemenuhan kebutuhan energi berbahan biogas bersumber dari bantuan Kementerian Lingkungan Hidup yaitu sebagian memenuhi kebutuhan dalam kategori rendah (20,59\%) dan tidak memenuhi kebutuhan dalam kategori cukup (79,41\%). Biodigester bantuan dari Diskepenak yaitu memenuhi kebutuhan termasuk agak rendah (40\%), sebagian memenuhi kebutuhan termasuk agak rendah (40\%), dan tidak memenuhi kebutuhan termasuk rendah (20\%). Biodigester bantuan dari instansi lain yaitu memenuhi kebutuhan (50\%) dan tidak memenuhi kebutuhan (50\%) termasuk agak rendah.

Total pemenuhan kebutuhan energi berbahan biogas yaitu memenuhi kebutuhan dalam kategori sangat rendah (9,3\%), sebagian memenuhi kebutuhan dalam kategori rendah (20,93\%), dan tidak memenuhi kebutuhan dalam kategori cukup $(69,77 \%)$. Jika tiga instansi dibandingkan dalam pemenuhan kebutuhan energi berbahan biogas maka kriteria memenuhi kebutuhan yang tertinggi yaitu bantuan dari instansi lain, kemudian dari Diskepenak. Kriteria memenuhi sebagian kebutuhan yaitu bantuan dari Diskepenak, selanjutnya dari Kementerian Lingkungan Hidup. Kriteria tidak memenuhi kebutuhan yang tertinggi yaitu dari bantuan Kementerian Lingkungan Hidup, instansi lain dan Diskepenak.

Salah seorang informan bernama Tugiyanto menerangkan bahwa jumlah produksi biogas tiga ekor sapi lebih banyak dibandingkan satu ekor. Muh. Paino, Tugiran, Rajiyo, dan Supadi mengemukakan bahwa kebutuhan biogas untuk harian terpenuhi.
Biodigester keempat informan tersebut berasal dari bantuan Diskepenak dan instansi lain dengan kapasitas $6 \mathrm{~m}^{3}$ dan $9 \mathrm{~m}^{3}$. Biodigester Sutopo berasal dari Kementerian Lingkungan Hidup dengan kapasitas 4,5 m³. Biogas Sutopo hanya memenuhi sebagian kebutuhan.

Biodigester bantuan Kementerian Lingkungan Hidup hanya sebagian memenuhi kebutuhan. Pemenuhan kebutuhan energi berbahan biogas bantuan dari Diskepenak dan instansi lain lebih baik jika dibandingkan bantuan dari Kementerian Lingkungan Hidup. Biodigester bantuan dari Kementerian Lingkungan Hidup bocor di sambungan. Kapasitas dan konstruksi biodigester mempengaruhi volume gas yang ditampung. Jika volume gas sedikit maka biogas tidak mampu memenuhi kebutuhan.

\section{Kendala-kendala dalam Pemanfaatan Biogas di Desa Pendoworejo}

Pemanfaatan biogas oleh masyarakat di Desa Pendoworejo tidak terlepas dari berbagai kendala. Kendala-kendala dalam pemanfaatan biogas di Desa Pendoworejo secara rinci dapat dilihat dalam tabel 7.

Kendala-kendala pemanfaatan biogas dalam tabel 7 yakni aspek bahan baku, teknis, lingkungan, sosial ekonomi, manajemen dan keberlanjutan. Aspek teknis, sosial ekonomi, dan keberlanjutan merupakan kendala-kendala yang utama. Berdasarkan aspek bahan baku maka kendala yang paling dominan yaitu jumlah sapi menurun. Bak, tutup biodigester, atau peralon bocor, dan kompor atau genset rusak merupakan kendala utama dari aspek teknis. Aspek lingkungan yang paling dominan berupa protes pencemaran limbah. Kendala utama dari aspek sosial ekonomi yakni malas mengisi biodigester, pemeliharaan yang rumit dan 
Dyah Sri Palupi -- Efektivitas Pemanfaatan Biogas Untuk Menunjang Ketahanan Energi (Studi Di Desa Pendoworejo Kecamatan Girimulyo Kabupaten Kulon Progo Daerah Istimewa Yogyakarta)

Tabel 7. Kendala-kendala dalam pemanfaatan biogas di Desa Pendoworejo

\begin{tabular}{|c|c|c|c|c|c|c|}
\hline & \multicolumn{6}{|c|}{ Aspek } \\
\hline & Bahan baku & Teknis & Lingkungan & Sosial ekonomi & Manajemen & Keberlanjutan \\
\hline 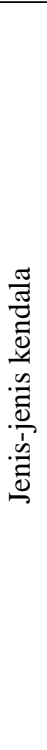 & $\begin{array}{l}\text { 1. Sapi mati atau } \\
\text { dijual } \\
\text { 2. Sapi diganti } \\
\text { domba } \\
\text { 3. Jumlah sapi } \\
\text { menurun } \\
\text { 4. Jumlah } \\
\text { kandang } \\
\text { kelompok } \\
\text { masih sedikit }\end{array}$ & $\begin{array}{l}\text { 1. Bak, tutup } \\
\text { biodigester, atau } \\
\text { peralon bocor } \\
\text { 2. Ketersediaan air } \\
\text { kurang } \\
\text { 3. Kompor atau } \\
\text { genset rusak } \\
\text { 4. Plastik } \\
\text { penampung gas } \\
\text { bocor } \\
\text { 5. Bak pencampur } \\
\text { sejajar lantai } \\
\text { kandang } \\
\text { 6. Bak } \\
\text { pembuangan } \\
\text { penuh } \\
\text { 7. Tidak ada } \\
\text { saluran limbah } \\
\text { 8. Kesalahan } \\
\text { konstruksi }\end{array}$ & $\begin{array}{l}\text { 1. Protes } \\
\text { pencemaran } \\
\text { limbah } \\
\text { 2. Kesulitan akses } \\
\text { sumber air } \\
\text { 3. Tanah bergerak } \\
\text { 4. Konstruksi bak } \\
\text { pencerna dekat } \\
\text { mata air } \\
\text { 5. Kondisi tanah } \\
\text { miring } \\
\text { 6. Keamanan } \\
\text { dan pencurian } \\
\text { ternak }\end{array}$ & $\begin{array}{l}\text { 1. Malas mengisi } \\
\text { biodigester } \\
\text { 2. Pemeliharaan } \\
\text { yang rumit } \\
\text { dan kesibukan } \\
\text { peternak } \\
\text { 3. Perpindahan } \\
\text { domisili } \\
\text { 4. Kekurangan } \\
\text { dana } \\
\text { 5. Hambatan } \\
\text { perbaikan sarana } \\
\text { prasarana } \\
\text { 6. Pengisian } \\
\text { biodigester } \\
\text { terlalu cepat dan } \\
\text { banyak } \\
\text { 7. Pecampuran } \\
\text { bahan kurang } \\
\text { homogen }\end{array}$ & $\begin{array}{l}\text { 1. Belum ada } \\
\text { tim pengelola } \\
\text { biogas } \\
\text { 2. Koordinasi } \\
\text { antar instansi } \\
\text { terkait kurang } \\
\text { optimal } \\
\text { 3. Koordinasi } \\
\text { antar } \\
\text { peternak, } \\
\text { kelompok } \\
\text { tani, } \\
\text { gapoktan, } \\
\text { penyuluh, } \\
\text { tomas, dan } \\
\text { pemerintah } \\
\text { belum optimal }\end{array}$ & $\begin{array}{l}\text { 1. Belum ada } \\
\text { yang membuat } \\
\text { biodigester } \\
\text { mandiri } \\
\text { 2. Jumlah } \\
\text { biodigester } \\
\text { yang berfungsi } \\
\text { menurun } \\
\text { 3. Keluhan biogas } \\
\text { macet } \\
\text { 4. Limbah } \\
\text { biogas belum } \\
\text { dikembangkan } \\
\text { 5. Belum bermitra } \\
\text { dengan Badan } \\
\text { Usaha Milik } \\
\text { Negara atau } \\
\text { perusahaan } \\
\text { swasta }\end{array}$ \\
\hline
\end{tabular}

Sumber: Analisis data primer, 2015.

kesibukan peternak, serta hambatan perbaikan sarana prasarana. Kendala dominan dari aspek manajemen yaitu belum ada tim pengelola biogas. Kendala utama dari aspek keberlanjutan yaitu limbah biogas belum dikembangkan dan belum bermitra dengan Badan Usaha Milik Negara atau perusahaan swasta.

\section{Strategi-strategi Prospektif dalam Mengatasi Kendala-kendala Pemanfaatan Biogas di Desa Pendoworejo}

Upaya mengatasi kendala-kendala dalam pemanfaatan biogas di Desa Pendoworejo sebagian telah dilakukan. Strategi-strategi prospektif dalam mengatasi kendala-kendala pemanfaatan biogas dapat dilihat dalam tabel 8.

Enam aspek dari strategi-strategi prospektif dalam tabel 8 yakni pemenuhan bahan baku, perbaikan teknis, pengendalian lingkungan, pengembangan sosial ekonomi, pengoptimalan manajemen dan pengembangan keberlanjutan. Strategi-strategi prospektif yang utama yakni perbaikan teknis, pengembangan sosial ekonomi, dan pengembangan keberlanjutan. Strategi prospektif dari aspek pemenuhan bahan baku yaitu kredit lunak untuk membeli sapi. Aspek perbaikan teknis dapat dilaksanakan dengan memperbaiki bak, tutup biodigester, atau pralon, membersihkan kompor atau genset rutin dan membuat kompor sederhana.

Strategi prospektif dari aspek pengendalian lingkungan yakni sosialisasi yang komprehensif pada tetangga sekitar. Aspek pengembangan sosial ekonomi dapat dilakukan dengan memotivasi supaya tidak malas dan bosan, gotong rotong anggota kelompok tani, dan membangun fasilitas pendukung perbaikan sarana prasarana. Strategi prospektif dari aspek pengoptimalan manajemen yaitu membentuk tim pengelola biogas. Aspek pengembangan keberlanjutan dapat dilaksanakan dengan mengembangkan 
Tabel 8. Strategi-strategi prospektif dalam mengatasi kendala-kendala pemanfaatan biogas di Desa Pendoworejo

\begin{tabular}{|c|c|c|c|c|c|c|}
\hline & \multicolumn{6}{|c|}{ Aspek } \\
\hline & $\begin{array}{l}\text { Pemenuhan bahan } \\
\text { baku }\end{array}$ & Perbaikan teknis & $\begin{array}{l}\text { Pengendalian } \\
\text { lingkungan }\end{array}$ & $\begin{array}{l}\text { Pengembangan } \\
\text { sosial ekonomi }\end{array}$ & $\begin{array}{l}\text { Pengoptimalan } \\
\text { manajemen }\end{array}$ & $\begin{array}{c}\text { Pengembangan } \\
\text { berkelanjutan }\end{array}$ \\
\hline 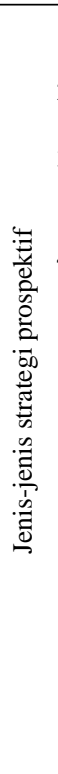 & $\begin{array}{l}\text { 1. Introduksi pola } \\
\text { gadhuh sapi } \\
\text { 2. Merendam } \\
\text { kotoran domba } \\
\text { 3. Kredit lunak } \\
\text { untuk membeli } \\
\text { sapi } \\
\text { 4. Mengem } \\
\text { bangkan kandang } \\
\text { kelompok }\end{array}$ & $\begin{array}{l}\text { 1. Memperbaiki bak, } \\
\text { tutup biodigester } \\
\text { atau pralon } \\
\text { 2. Penyediaan air } \\
\text { yang mencukupi } \\
\text { 3. Membersih } \\
\text { kan kompor, } \\
\text { genset rutin atau } \\
\text { membuat kompor } \\
\text { sederhana } \\
\text { 4. Mengganti plastik } \\
\text { dengan fiber } \\
\text { 5. Membuat bak } \\
\text { pencampur lebih } \\
\text { rendah dari lantai } \\
\text { kandang } \\
\text { 6. Menguras bak } \\
\text { penampungan } \\
\text { rutin } \\
\text { 7. Membuat saluran } \\
\text { limbah } \\
\text { 8. Memperbaiki } \\
\text { konstruksi }\end{array}$ & $\begin{array}{l}\text { 1. Sosialisasi yang } \\
\text { komprehensif } \\
\text { pada tetangga } \\
\text { sekitar } \\
\text { 2. Menyalurkan air } \\
\text { dari sumber } \\
\text { 3. Penggunaan } \\
\text { bahan tahan tanah } \\
\text { bergerak } \\
\text { 4. Menguras dekat } \\
\text { mata air } \\
\text { 5. Membuat } \\
\text { penyangga atau } \\
\text { menimbun } \\
\text { 6. Menjaga ternak } \\
\text { secara teratur }\end{array}$ & $\begin{array}{l}\text { 1. Memotivasi } \\
\text { supaya tidak } \\
\text { malas dan bosan } \\
\text { 2. Gotong rotong } \\
\text { anggota } \\
\text { kelompok tani } \\
\text { 3. Mengerahkan } \\
\text { pemuda } \\
\text { 4. Kredit lunak } \\
\text { untuk perbaikan } \\
\text { 5. Membangun } \\
\text { fasilitas } \\
\text { pendukung } \\
\text { perbaikan sarana } \\
\text { prasarana } \\
\text { 6. Mengisi } \\
\text { biodigester } \\
\text { secukupnya } \\
\text { 7. Mencampur } \\
\text { bahan hingga } \\
\text { homogen }\end{array}$ & $\begin{array}{l}\text { 1. Membentuk tim } \\
\text { pengelola biogas } \\
\text { 2. Meningkatkan } \\
\text { koordinasi antar } \\
\text { instansi } \\
\text { 3. Meningkatkan } \\
\text { koordinasi } \\
\text { antar peternak, } \\
\text { gapoktan, } \\
\text { kelompok tani, } \\
\text { penyuluh, tomas, } \\
\text { dan pemerintah }\end{array}$ & $\begin{array}{l}\text { 1. Memotivasi } \\
\text { pembangunan } \\
\text { biodigester } \\
\text { mandiri } \\
\text { 2. Mempertahankan } \\
\text { biodigester yang } \\
\text { berfungsi } \\
\text { 3. Sosialisasi biogas } \\
\text { tidak macet } \\
\text { 4. Mengembangkan } \\
\text { usaha baru dari } \\
\text { limbah biogas } \\
\text { 5. Bermitra dengan } \\
\text { Badan Usaha } \\
\text { Milik Negara } \\
\text { atau perusahaan } \\
\text { swasta }\end{array}$ \\
\hline
\end{tabular}

Sumber: Analisis data primer, 2015.

usaha baru dari limbah biogas dan bermitra dengan Badan Usaha Milik Negara atau perusahaan swasta.

\section{Efektivitas Pemanfaatan Biogas di Desa Pendoworejo}

Biodigester yang berfungsi yaitu sebanyak 30,26\% dan kondisi rusak sebanyak 69,77\%. Persentase efektivitas kontinuitas ketersediaan dan pemanfaatan biogas untuk pemanfaatan harian dalam kategori rendah (25,58\%), pemanfaatan kadang-kadang dalam kategori sangat rendah (4,65\%), dan kondisi rusak dalam kategori cukup (69,77\%). Persentase efektivitas pemanfaatan dan fungsi biogas untuk memasak termasuk tinggi (86,82\%), genset termasuk sangat rendah $(3,1 \%)$ dan lainnya termasuk sangat rendah (10,08\%). Persentase efektivitas yang memenuhi kebutuhan tergolong sangat rendah $(9,3 \%)$, sebagian tergolong rendah (20,93\%) dan tidak memenuhi tergolong cukup
(69,77\%). Efektivitas pemanfaatan biogas di Desa Pendoworejo termasuk dalam kriteria rendah.

\section{Hubungan Efektivitas Pemanfaatan Biogas Dengan Ketahanan Energi di Desa Pendoworejo}

Masyarakat Desa Pendoworejo menggunakan bahan bakar berupa kayu bakar, LPG dan biogas. Penggunaan bahan bakar berdasarkan informasi yang berasal dari informan peternak berbeda-beda yaitu: (1) kayu bakar, (2) LPG, (3) biogas, (4) kayu bakar dan LPG, (5) kayu bakar dan biogas, (6) LPG dan biogas, dan (7) kayu bakar, LPG, dan biogas. Kementerian Pembangunan Daerah Tertinggal (PDT) memberikan bantuan untuk pengembangan peternakan. Bantuan berupa dana bergulir dan empat unit biodigester diberikan di Desa Pendoworejo. Pemerintah Kabupaten Kulon Progo berharap bantuan 
biodigester akan mewujudkan DME di Desa Pendoworejo (Pemerintah Kabupaten Kulon Progo, 2010). Desa Mandiri Energi merupakan desa yang lebih dari $60 \%$ kebutuhan listrik dan bahan bakar dipenuhi dari sumber energi terbarukan (Kementerian Energi dan Sumber Daya Mineral, 2015).

Jumlah KK di Desa Pendoworejo per tanggal 31 Januari 2015 yaitu 1.951. Jumlah KK yang memiliki biodigester yaitu 183 (9,38 \%). Jika efektivitas pemanfaatan biogas dibandingkan dengan jumlah sumber energi terbaharukan maka masih jauh dari harapan. Jumlah sumber energi DME yaitu lebih dari 60\%, sedangkan jumlah biodigester termasuk rendah (9,38\%). Jumlah biodigester yang memenuhi kebutuhan dalam kategori sangat rendah $(9,3 \%)$ dan sebagian memenuhi kebutuhan dalam kategori rendah (20,93\%). Efektivitas pemanfaatan biogas di Desa Pendoworejo belum dapat menunjang ketahanan energi.

\section{SIMPULAN}

Berdasarkan hasil penelitian yang dilakukan di Desa Pendoworejo maka dapat diambil simpulan sebagai berikut:

Pertama, efektivitas pemanfaatan biogas di Desa Pendoworejo masih tergolong dalam kategori rendah. Biodigester yang berfungsi sebanyak $30,26 \%$ dan kondisi rusak sebanyak 69,77\%. Pemanfaatan biogas di Desa Pendoworejo dapat ditingkatkan dengan beberapa cara yakni: (1) Membentuk tim pengelola biogas; (2) Memotivasi masyarakat melalui penyuluhan dan pertemuan kelompok; (3) Gotong royong untuk memperbaiki biodigester; (4) Mengelola limbah biogas untuk pupuk padat dan cair; (5) Menyediakan kredit lunak untuk membeli sapi; (6) Membuat kompor sederhana; dan (7) Membangun biodigester yang berkualitas dan fasilitas pendukung perbaikan sarana dan prasarana.

Kedua, hubungan efektivitas pemanfaatan biogas di Desa Pendoworejo dengan ketahanan energi yaitu efektivitas pemanfaatan biogas belum mampu menunjang ketahanan energi. Jumlah KK di Desa Pendoworejo yaitu 1.951 dan jumlah KK yang memiliki biodigester yaitu 183 (9,38\%). Sumber energi terbaharukan dari biogas belum mencapai lebih dari $60 \%$. Harapan Desa Pendoworejo menjadi Desa Mandiri Energi belum dapat terwujud.

\section{DAFTAR PUSTAKA}

Arikunto, Suharsini. 1998. Prosedur Penelitian: Suatu Pendekatan Praktik. Jakarta: Bina Aksara.

Campbell, Ian. 1983. Biomass, Catalysts and Liquid Fuels. Great Britain: Holt Rinehart and Wiston Ltd.

Dirwan, A. 2012. "Peningkatan Ketahanan Pangan dan Energi sebagai Bagian dari Perwujudan Ketahanan Nasional”. Jurnal Mitra Manajemen. Vol. 4. No. 1.

Elizabeth, Roosganda dan S. Rusdiana. 2011. Efektivitas Pemanfaatan Biogas sebagai Sumber Bahan Bakar dalam Mengatasi Biaya Ekonomi Rumah Tangga di Pedesaan. Bogor: Pusat Sosial Ekonomi dan Kebijakan Pertanian.

Indrawan, Natarianto dan Muhammad Ery Wijaya. 2011. "Addressing Palm Biodiesel as Renewable Fuel for the Indonesian Power Generation Sector: Java-MaduraBali System”. The Journal for Technology and Science. Vol. 22. No. 4.

Nugroho, Hanan. 2005. Apakah Persoalannya pada Subsidi BBM? Tinjauan terhadap Masalah Subsidi BBM, Ketergantungan pada Minyak Bumi, Manajemen 
Energi Nasional, dan Pembangunan Infrastruktur Energi. Jakarta: Badan Perencanaan Nasional.

Nurhasanah, Ana, Teguh Wikan Widodo, Ahmad Asari, dan Elita Rahmarestia. 2006. Perkembangan Digester Biogas di Indonesia (Studi Kasus di Jawa Barat dan Jawa Tengah). Serpong: Balai Besar Pengembangan Mekanisasi Pertanian.

PIM-LPPM. 1997. Kamus Istilah Manajemen. Jakarta: PT. Pustaka Binaman Pressindo.

Prasetyo, Yanu Endar dan Umi Hanifah. 2011. “Pengorganisasian Masyarakat Desa Mandiri Energi: Studi Kasus PLTMH di Desa Palakka, Kecamatan Maiwa, Kabupaten Enrekang, Sulawesi Selatan”. Jurnal Komunitas. Volume 5. Nomor 1.

\section{Internet:}

Kementerian Energi dan Sumber Daya Mineral. 2015. Laporan Akuntabilitas Kinerja
Instansi Pemerintah (LAKIP) Direktorat Jenderal Energi Baru, Terbarukan dan Konservasi Energi Tahun 2013. <http:// ebtke.esdm.go.id/post/2014/07/16/637/ lakip.ditjen.ebtke.2013> (diakses 13 Maret 2015).

Pemerintah Kabupaten Kulon Progo. 2010. Kementerian PDT Tetap Kucurkan Bantuan untuk Kulon Progo. <http:// www.kulonprogokab.go.id/v21> (diakses 13 Maret 2015).

\section{Wawancara:}

1. Idhiar Nugroho, Dinas Perindustrian, Perdagangan dan ESDM

2. Muh. Paino: Tokoh Masyarakat/Peternak

3. Tugiyanto: Tokoh Masyarakat/Peternak

4. Tugiran: Tokoh Masyarakat/Peternak

5. Rajiyo: Tokoh Masyarakat/Peternak

6. Supadi: Tokoh Masyarakat/Peternak 


\title{
DISKRESI ANGGOTA Kepolisian NEGARA REPUBLIK INDONESIA DALAM PENANGANAN AKSI UNJUK RASA DAN IMPLIKASINYA TERHADAP KETAHANAN WILAYAH (Studi Di Kepolisian Resort Kota Yogyakarta)
}

\author{
Legowo Saputro \\ Polda DIY \\ Email: mobrig05@yahoo.com
}

\begin{abstract}
This research aimed to, firstly, determining the application of Police Officers discretion on handling of protest action, related forms of action and consideration, constraints and secondly, implications aginst the regional resilience.

This research used qualitative descriptive method of search and data collection in the form of opinions or ideas, phenomena, portrait and documents related to Police Officers discretion on handling of protest action. Data obtained by in depth interviews, observation and studied of literature and documents, which were then analyzed and put in the form of words and portrait that gave an obvious illustration of the object of research. Research was conducted at the Police Resort of Yogyakarta City by taking samples of some Police Officers of Yogyakarta City and Police Department of Yogyakarta, protesters, public, and legal advisor.

The Discretion applied by the Police Officers of Yogyakarta City on handling of protest action that formed of tolerance for violations of protesters in terms of notification and implementation of the protest action, and the action as well as a waiver of any provision in the handling of demonstrations by the police. The constraints that formed in limited and superficially understanding of the discretion by the police, the sanctions provided were personaly, negative responses from the public and the protesters. The discretion of the Police Officers of Yogyakarta City in handling of protest action effected: Firstly, positive effect that created stability of the region of Yogyakarta City and had impact on regional resilience on aspects of ideological, political, social, cultural and security; Secondly, negative consequences in the form of public perception that the violation by protesters was the right thing, when discretion were applied was not well understood by the police. Existing obstacles must be overcame to provide sufficient understanding and knowledge of police discretion, especially to the Police Department of Yogyakarta City, and to the public and protesters.
\end{abstract}

Keywords: Police Discretion, Protest Action, The Regional Resilience.

\begin{abstract}
ABSTRAK
Penelitian ini bertujuan untuk: Pertama, mengetahui penerapan diskresi anggota kepolisian dalam penanganan aksi unjuk rasa, terkait bentuk tindakan dan pertimbangannya serta kendala; dan Kedua, implikasinya terhadap ketahanan wilayah.

Penelitian ini menggunakan metode deskriptif kualitatif yaitu pencarian dan pengumpulan data yang berupa pendapat atau gagasan, fenomena, gambar serta dokumen yang berkaitan dengan diskresi anggota kepolisian dalam penanganan aksi unjuk rasa. Data diperoleh dengan wawancara mendalam, pengamatan serta studi kepustakaan dan dokumen, yang selanjutnya dianalisis dan dituangkan dalam bentuk kata-kata dan gambar sehingga memberikan
\end{abstract}


gambaran yang jelas tentang obyek penelitian. Penelitian dilakukan di Kepolisian Resort Kota Yogyakarta dengan mengambil sampel beberapa Anggota Polresta Yogyakarta dan Polda DIY, pengunjuk rasa, masyarakat,dan ahli hukum.

Diskresi yang diterapkan oleh Anggota Kepolisian Resort Kota Yogyakarta dalam penanganan aksi unjuk rasa berupa toleransi atas pelanggaran pengunjuk rasa dalam hal surat pemberitahuan dan pelaksanaan aksi unjuk rasa, dan tindakan tersebut sekaligus merupakan pengabaian ketentuan dalam penanganan aksi unjuk rasa oleh Polisi. Kendalanya berupa pemahaman yang sempit serta dangkal terhadap diskresi oleh Polisi, sanksi yang diberikan bersifat personal, tanggapan negatif dari masyarakat dan pengunjuk rasa. Diskresi Anggota Kepolisian Resort Kota Yogyakarta dalam penanganan aksi unjuk rasa berakibat, yaitu: Pertama, akibat positif berupa terciptanya stabilitas wilayah di Kota Yogyakarta dan berdampak terhadap ketahanan wilayah pada aspek ideologi, politik, sosial budaya dan keamanan; Kedua yaitu, akibat negatif berupa anggapan masyarakat bahwa pelanggaran yang dilakukan oleh pengunjuk rasa merupakan hal yang benar, apabila diskresi yang diterapkan tidak dipahami dengan baik oleh Polisi. Kendala yang ada harus diatasi dengan memberikan pemahaman dan pengetahuan yang cukup tentang diskresi kepolisian, khususnya kepada Anggota Kepolisian Resort Kota Yogyakarta, dan kepada masyarakat maupun pengunjuk rasa.

\section{Kata kunci: Diskresi Anggota Kepolisian, Unjuk Rasa, Ketahanan Wilayah.}

\section{PENGANTAR}

Hukum pidana merupakan sistem yang dibangun oleh negara untuk melindungi masyarakat dalam kehidupan yang damai, aman dan tertib atas segala gangguan dari pelaku pelanggar norma. Dalam usaha menegakkan hukum pidana tersebut agar dipatuhi oleh masyarakat, berdasarkan undangundang negara menugaskan Polisi untuk usaha tersebut. Polisilah yang mempunyai kekuasaan sangat besar dalam hal penegakkan hukum. Untuk menjalankan kekuasaan yang besar tersebut, Polri diberikan kewenangan, salah satunya terdapat dalam Pasal 5 Ayat (1) Huruf a Angka 4, Pasal 7 Ayat (1) Huruf j, dan Pasal 16 Ayat (1) Undang-undang Nomor 2 Tahun 2002 tentang Kepolisian Negara Republik Indonesia, “...Untuk kepentingan umum, pejabat Kepolisian Negara Republik Indonesia dalam melaksanakan tugas dan wewenangnya dapat bertindak menurut penilaiannya sendiri...”, atau biasa disebut dengan “diskresi”. Diskresi diartikan sebagai kebebasan mengambil keputusan dalam setiap situasi yang dihadapi menurut pendapat sendiri (Simorangkir dkk, 1980:45), sedangkan menurut Aaron (1960:ix), bahwa diskresi merupakan suatu kekuasaan atau wewenang yang dilakukan berdasarkan hukum atas pertimbangan dan keyakinan serta lebih menekankan pertimbangan moral dari pada pertimbangan hukum, selain itu diskresi yang dilakukan oleh Polisi juga dipengaruhi oleh kondisi lingkungan, masyarakat, kepentingan, dan situasi politik. Menurut Faal (1991:144145) bahwa peranan diskresi kepolisian untuk menyatukan tugas pokok yang diemban oleh Polisi yaitu sebagai penjaga keamanan dan ketertiban masyarakat yang dalam pencapaiannya direalisasikan dalam tugas preventif dan tugas represif. Kedua tugas tersebut harus selalu menyatu dalam diri seorang Polisi, ia menindak pelanggar hukum sekaligus membina masyarakat, sebagai penegak hukum sekaligus pembina masyarakat. Kedua tugas tersebut kadang selaras, namun sering juga bertentangan. Di situlah peranan diskresi tersebut. Polisi harus dapat dengan bijaksana menentukan alternatif tindakan apa yang harus dilakukan, yang paling tepat dan paling ia yakini kemanfaatannya, baik dari segi hukum, korban, pelaku, dan masyarakat.

Ridwan (2014:5) dalam "Diskresi dan Tanggung Jawab Pemerintah” menyebutkan 
Legowo Saputro -- Diskresi Anggota Kepolisian Negara Republik Indonesia Dalam Penanganan Aksi Unjuk Rasa Dan Implikasinya Terhadap Ketahanan Wilayah

(Studi Di Kepolisian Resort Kota Yogyakarta)

bahwa, pemberian kewenangan diskresi atau dikenal juga dengan freis ermessen, yaitu kemerdekaan pemerintah untuk dapat bertindak atas inisiatif sendiri dalam menyelesaikan persoalan-persoalan sosial, didasarkan kepada konsepsi negara hukum modern seperti yang dianut oleh Indonesia telah menimbulkan dilema yang penuh kontradiksi, sebab bagi suatu negara hukum modern, setiap tindakan pemerintahannya harus berdasarkan atas hukum atau setidaktidaknya tidak boleh bertentangan dengan hukum, baik hukum tertulis maupun hukum tidak tertulis, sedangkan bersamaan dengan itu kepada pemerintah diserahi pula peran, tugas, dan tanggung jawab yang semakin luas serta berat. Artinya acapkali terjadi kesenjangan antara asas legalitas dengan realitas yang dihadapi pemerintah. Kemerdekaan atau kebebasan pemerintah tersebut mencakup kebebasan interpretasi, kebebasan mempertimbangkan, dan kebebasan mengambil kebijakan (Ridwan, 2014:16).

Dasar hukum pelaksanaan diskresi oleh kepolisian bersumber pada Pembukaan Undang-undang Dasar Negara Republik Indonesia 1945 alenia ke empat, yurisprudensi, Undang-undang Nomor 2 Tahun 2002 tentang Kepolisian Negara Republik Indonesia Pasal 18 Ayat (1), dan Undang-undang Nomor 8 Tahun 1981 tentang KUHAP Pasal 5 Ayat (1) Huruf a Angka 4 dan Pasal 7 Ayat 1 Huruf j, yang secara garis besar menyatakan bahwa, “Demi kepentingan umum, setiap Pejabat Kepolisian Negara Republik Indonesia dalam melaksanakan tugas dan wewenangnya dapat bertindak menurut penilaiannya sendiri”.

Diskresi dapat diterapkan dalam semua lingkup tugas kepolisian baik dalam tugas represif atau penegakkan hukum maupun preventif atau pencegahan berupa pemeliharaan ketertiban masyarakat termasuk dalam hal penanganan unjuk rasa. Kewenangan diskresi tersebut sangat besar karena hanya berdasar penilaian petugas Polisi dan belum jelas batasannya, sehingga mempunyai kecenderungan terhadap terjadinya penyalahgunaan wewenang. Penelitian tentang diskresi khususnya yang dilakukan oleh Anggota Polri kebanyakan terkait penegakkan hukum, dan hampir tidak ada penelitian tersebut berkaitan dengan pemeliharaan ketertiban umum, padahal dalam lingkup tugasnya, Polri lebih banyak bertugas dalam hal pemeliharaan ketertiban umum, sehingga mempunyai peluang yang lebih besar diterapkannya diskresi dan berpeluang besar pula untuk terjadinya penyalahgunaan wewenang, demikian halnya dalam penanganan unjuk rasa, peluang diterapkannya diskresi tersebut sangat besar dan berbanding lurus dengan kemungkinan terjadinya penyalahgunaan wewenang.

Tujuan penelitian ini untuk mengetahui dan mengkaji penerapan diskresi yang berupa bentuk tindakan, alasan atau pertimbangan, pola, syarat, dan kendala oleh Anggota Kepolisian Resort Kota Yogyakarta dalam penanganan aksi unjuk rasa di Kota Yogyakarta, serta untuk mengetahui implikasi dari penerapan diskresi oleh Anggota Kepolisian Resort Kota Yogyakarta dalam penanganan aksi unjuk rasa terhadap ketahanan wilayah (Sunardi, 2004).

\section{PEMBAHASAN}

Diskresi Anggota Kepolisian Resort Kota Yogyakarta dalam Penanganan Aksi Unjuk Rasa

Ketentuan Pasal 10 Ayat (1) dan Ayat (3) Undang-undang Nomor 9 Tahun 1998 tentang Kemerdekaan Menyampaikan Pendapat di Muka Umum, mewajibkan penyampaian 
Tabel. 1

Data Surat Pemberitahuan Aksi Unjuk Rasa di Kota Yogyakarta

\begin{tabular}{|c|c|c|c|c|c|c|c|c|c|c|c|c|c|c|}
\hline \multirow{2}{*}{ No } & \multirow{2}{*}{ Tahun } & \multicolumn{12}{|c|}{ Bulan } & \multirow{2}{*}{ Jumlah } \\
\hline & & Jan & Feb & Mar & Apr & Mei & Jun & Jul & Agu & Sep & Okt & Nov & Des & \\
\hline 1 & 2011 & 1 & 1 & 3 & 7 & 7 & 2 & 4 & 0 & 2 & 5 & 0 & 4 & 36 \\
\hline 2 & 2012 & 3 & 2 & 5 & 3 & 4 & 3 & 1 & 0 & 1 & 4 & 6 & 4 & 36 \\
\hline 3 & 2013 & 1 & 3 & 5 & 4 & 8 & 1 & 0 & 1 & 0 & 4 & 7 & 3 & 37 \\
\hline 4 & 2014 & 0 & 4 & 2 & 4 & 2 & 3 & 0 & 1 & 7 & 6 & 11 & 0 & 40 \\
\hline Jumlah & & 5 & 10 & 15 & 18 & 21 & 9 & 5 & 2 & 10 & 19 & 24 & 11 & 149 \\
\hline
\end{tabular}

Sumber: Satintelkam Polresta Yogyakarta Tahun 2014.

Tabel. 2

Data Unjuk Rasa di Kota Yogyakarta Tahun 2011-2014

\begin{tabular}{|c|c|c|c|c|c|c|c|c|c|c|c|c|c|c|}
\hline \multirow{2}{*}{ No } & \multirow{2}{*}{ Tahun } & \multicolumn{12}{|c|}{ Bulan } & \multirow{2}{*}{ Tota } \\
\hline & & Jan & Feb & Mar & Apr & Mei & Jun & Jul & Agu & Sep & Okt & Nov & Des & \\
\hline 1 & 2011 & 9 & 9 & 9 & 14 & 21 & 13 & 17 & 5 & 14 & 23 & 10 & 21 & 165 \\
\hline 2 & 2012 & 10 & 7 & 51 & 7 & 16 & 9 & 12 & 7 & 9 & 19 & 11 & 16 & 174 \\
\hline 3 & 2013 & 12 & 12 & 8 & 23 & 24 & 20 & 8 & 9 & 13 & 13 & 17 & 10 & 169 \\
\hline 4 & 2014 & 10 & 9 & 13 & 11 & 15 & 12 & 22 & 7 & 17 & 23 & 24 & 9 & 172 \\
\hline \multicolumn{2}{|c|}{ Jumlah } & 41 & 37 & 81 & 55 & 76 & 54 & 59 & 28 & 53 & 78 & 62 & 56 & 680 \\
\hline
\end{tabular}

Sumber: Sat Intelkam Polresta Yogyakarta Tahun 2014.

pendapat di muka umum, diberitahukan secara tertulis kepada Polri selambat-lambatnya 3x24 jam sebelum kegiatan dimulai. Kenyataannya ketentuan tersebut sulit dipenuhi oleh pengunjuk rasa, sebagaimana tabel 1 dan 2 .

Berdasarkan tabel 1 dapat diketahui jumlah surat pemberitahuan unjuk rasa yang disampaikan kepada Polresta Yogyakarta, sedangkan tabel 2 menjelaskan jumlah kegiatan unjuk rasa yang dilakukan di Kota Yogyakarta. Sesuai data tersebut dapat dijelaskan bahwa surat pemberitahuan aksi unjuk rasa yang masuk di Unit Pelayanan Perijinan Satintelkam Polresta Yogyakarta dalam kurun waktu Tahun 2011-2014 hanya 149 kali atau 22\% saja dari 680 kali aksi unjuk rasa yang dilakukan. Apabila dilihat perbulannya bahkan ada aksi unjuk rasa yang tanpa mengirimkan surat pemberitahuan yaitu di Bulan Agustus Tahun 2011 dan Tahun 2012, Bulan November Tahun 2011, Bulan Juli Tahun 2013 dan Tahun 2014, serta Bulan
Januari dan Desember Tahun 2014.

Selain berdasarkan data di atas, penerapan diskresi berkaitan dengan surat pemberitahuan aksi unjuk rasa disampaikan oleh Wakapolresta Yogyakarta, AKBP Agustinus Supriyanto yang menyatakan bahwa tindakan Polresta Yogyakarta tersebut dilakukan sebagai bentuk penyesuaian terkait model pemberitahuan yang dapat dilakukan selain dengan surat pemberitahuan yakni dengan menggunakan media sosial seperti SMS, BBM ataupun email.

Aiptu Rubiyana, mengatakan bahwa:

"Terkait banyaknya aksi unjuk rasa tanpa disertai surat pemberitahuan tersebut, kelengkapan administrasi pengamanan aksi unjuk rasa juga tidak sesuai ketentuan, misalnya tidak dibuatnya rencana pengamanan dan surat perintah pengamanan yang berfungsi sebagai pertanggungjawaban secara administrasi dalam hal pengamanan suatu kegiatan masyarakat, yang berfungsi juga sebagai 
Legowo Saputro -- Diskresi Anggota Kepolisian Negara Republik Indonesia Dalam Penanganan Aksi Unjuk Rasa Dan Implikasinya Terhadap Ketahanan Wilayah

(Studi Di Kepolisian Resort Kota Yogyakarta)

pemberitahuan kepada anggota Polri tentang pelaksanaan kegiatan masyarakat. Sebagai ganti kelengkapan administrasi tersebut berkaitan dengan fungsinya sebagai pemberitahuan, dibuatlah surat telegram tentang suatu kegiatan unjuk rasa, dari segi kecepatan waktu, surat telegram lebih efektif, namun tidak dapat digunakan sebagai pertanggung jawaban secara administrasi" (Wawancara di Polresta Yogyakarta tanggal 11 Februari 2015).

Arahan pimpinan dalam rangka pengamanan unjuk rasa yang biasanya didahului dengan pelaksanaan apel, demi kecepatan kehadiran Polisi di lapangan, dilakukan dengan menggunakan alat komunikasi HT (Handy Talkie). Arahan yang dilakukan berisikan konsep pengamanan, cara bertindak, penempatan personil, serta larangan dalam pelaksanaan pengamanan aksi unjuk rasa. Ketersediaan HT yang terbatas, mengharuskan Perwira Pengendali (Padal) sebagai pemegang HT, menyampaikan kembali kepada anggota Polri di bawah tanggung jawabnya pada saat tiba di lokasi yang menjadi obyek dari unjuk rasa atau saat perjalanan menuju lokasi unjuk rasa.

Pelaksanaan pengamanan unjuk rasa, personil pengamanan tidak melakukan atau tidak melakukan seluruhnya tindakan yang sesuai Peraturan Kapolri Nomor 16 Tahun 2006 tentang Pedoman Pengendalian Massa (Dalmas). Bagian yang dilaksanakan yaitu kegiatan perekaman jalannya aksi, sedangkan personel Dalmas ditempatkan menjadi satu di area yang agak jauh, namun tetap di satu area dari sasaran aksi unjuk rasa dan tetap memantu perkembangannya, tidak dengan baris bersaf dengan menggunakan tali Dalmas di depan massa aksi. Anggota Pengendali Massa tidak melakukan formasi bersaf dengan tali Dalmas karena dengan tindakan tersebut dianggap sebagai penghalang oleh massa aksi dan justru akan menimbulkan ketegangan.

Polisi yang melakukan pemantauan dalam jarak dekat dengan massa aksi dan sasaran aksi hanya dari personil Intelijen, Padal dan beberapa anggota Dalmas. Selanjutnya himbauan oleh satuan Dalmas ataupun oleh satuan pendukung juga tidak dilakukan, yang dilakukan adalah model komunikasi antara Padal atau penanggung jawab lokasi secara face to face dengan korlap ataupun penanggung jawab aksi saat massa aksi memasuki area gedung. Himbauan dengan pengeras suara justru akan mengganggu orasi yang dilakukan oleh pelaku unjuk rasa dan hal tersebut tentu saja memicu sikap perlawanan dari massa aksi, lain halnya apabila himbauan dilakukan secara simpatik dan pribadi dengan penuh rasa hormat dan menaruh kepercayaan kepada koordinator/penanggung jawab aksi agar yang bersangkutan dapat menghimbau kepada seluruh massa aksi untuk tetap dapat menjaga ketertiban dan keamanan selama berlangsungnya aksi unjuk rasa.

Himbauan dengan cara tersebut dapat menjalin komunikasi yang lebih baik dengan massa aksi, sehingga hubungan yang terjalin bukan hanya pada saat pelaksanaan unjuk rasa, melainkan hubungan secara emosional secara terus menerus. Sebagaimana hal yang disampaikan oleh ketua DPRD DIY, Bapak Yuke yang menyatakan bahwa komunikasi merupakan hal yang paling penting dalam berbagai hal, termasuk dalam hal ini penyelesaian masalah. Menurutnya, dengan komunikasi akan terbuka ruang yang sebelumnya tertutup, dengan berkomunikasi akan tahu apa keinginan dari seseorang, begitu pula dalam unjuk rasa, komunikasi yang 
baik akan menurunkan tingkat ketegangan pada situasi unjuk rasa, mencairkan suasana, yang tadinya berapi-api berubah menjadi komunikatif, komunikasi merupakan awal dari sebuah hubungan, komunikasi yang baik akan melahirkan hubungan yang baik pula, namun hendaknya komunikasi dilakukan setiap saat, tidak hanya saat pelaksanaan aksi unjuk rasa, atau pada saat dibutuhkan saja, kapanpun dan di manapun jalinan komunikasi harus tetap dijaga dengan baik.

Aiptu Bambang Eko Lumaksono, mengatakan bahwa:

"Saat ini, Polisi terutama Padal atau Kanit tidak melakukan yang terbaik dalam pengamanan unjuk rasa. Mereka hanya melaporkan perkembangan situasi, pengamatan dan pengaturan lalu lintas, padahal mereka bisa lebih dari itu, seperti berkomunikasi atau sekedar "ngobrol" dengan peserta aksi unjuk rasa. Menurut Aiptu Bambang, bentuk komunikasi saat unjuk rasa tidak harus tentang unjuk rasa, keamanan, ketertiban, atau himbauan Polisi, tetapi bisa apa saja baik keluarga, kuliah atau hal lainnya. Dengan berkomunikasi seperti tersebut lawan bicara tidak merasa dan tidak seperti layaknya sedang diinterogasi, tetapi layaknya seorang teman, sehingga keakraban, rasa saling menghargai dan saling percaya akan timbul, yang pada akhirnya akan tercipta saling pengertian antara pengunjuk rasa dengan Polisi, sehingga tensi tinggi antara pengunjuk rasa dengan Polisi dan sasaran unjuk rasa dapat berkurang, konflik yang berujung kepada bentrokan fisik dapat terhindarkan" (Wawancara Aiptu Bambang Eko Lumaksono, Pejabat Sementara Kanit Dalmas B Sat Sabhara Polresta Yogyakarta, 6 Januari 2015).

Berdasarkan pengamatan peneliti, personil pengendali massa juga tidak menggunakan atau memakai pakaian, peralatan, dan sarana serta prasarana sesuai prosedur pengendalian massa seperti pakaian Dalmas, tali Dalmas, tameng, dan tongkat Dalmas. Peralatan tersebut juga tidak dipersiapkan di dalam kendaraan pengangkut peralatan di lokasi tempat unjuk rasa dilakukan. Selain itu, tahapan pelaksanaan pengamanan aksi unjuk rasa juga tidak dilakukan sesuai Peraturan Kapolri Nomor 16 Tahun 2006 tentang Pedoman Pengendalian Massa. Personil dalmas cenderung menyesuaikan dengan tindakan yang dilakukan oleh pengunjuk rasa.

Pertimbangan yang dipakai Anggota Polresta Yogyakarta pada penerapan diskresi dalam penanganan aksi unjuk rasa sebagai bentuk Public Order Maintenance yaitu: (1) Kepentingan umum, yakni kepentingan seluruh masyarakat Kota Yogyakarta dalam melaksanakan aktivitasnya, berkaitan dengan pelaksanaan aksi unjuk rasa; (2) Karakter pengunjuk rasa, yakni kebiasaan dalam berperilaku kelompok massa aksi tertentu yang telah ditandai atau berdasarkan analisis intelijen; (3) Isu/tema unjuk rasa. Hal ini berpengaruh terhadap konsep pengamanan yang akan dilaksanakan; (4) Jumlah pengunjuk rasa, yang ditentukan berdasarkan surat pemberitahuan atau perkiraan terkait aliansi yang dibentuk oleh pengunjuk rasa; (5) Jumlah petugas/kekuatan. Hal ini berkaitan dengan penerapan diskresi, semakin besar perbandingan jumlah petugas dengan pengunjuk rasa akan semakin mungkin diskresi diterapkan; (6) Lingkungan, Sarana dan Prasarana. Hal ini terutama berkaitan dengan efek yang ditimbulkan akibat penerapan diskresi khususnya dalam pengalihan arus lalu lintas.

Penerapan diskresi oleh petugas terdapat dalam skema gambar di bawah ini: 
Legowo Saputro -- Diskresi Anggota Kepolisian Negara Republik Indonesia Dalam Penanganan Aksi Unjuk Rasa Dan Implikasinya Terhadap Ketahanan Wilayah

(Studi Di Kepolisian Resort Kota Yogyakarta)

Gambar Skema Hirarki Penerapan Diskresi dalam Penanganan Aksi Unjuk Rasa

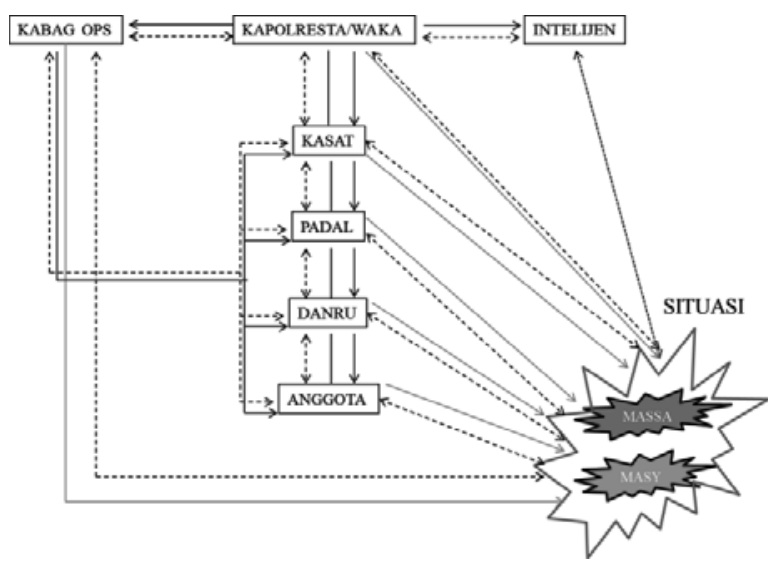

Sumber: Hasil olah data penelitian oleh peneliti 2015.

Gambar tersebut menjelaskan, garis panah hitam merupakan perintah (komando) untuk penerapan diskresi, garis putus-putus merupakan rantai koordinasi ataupun umpan balik. Apabila di dalam kesatuan Polisi disebut sebagai koordinasi yang berarti saran dan masukan antara bawahan dan atasan tentang situasi yang berkembang, sedangkan antara Polisi dan pengunjuk rasa dan masyarakat atau peneliti menyebutnya situasi dapat disebut sebagai koordinasi dan respon timbal balik, situasi yang terjadi bisa langsung direspon oleh Polisi tanpa ada keharusan untuk berkoordinasi dengan pimpinan apabila hal tersebut bersifat mendesak.

Menurut Guru Besar Hukum Pidana Universitas Gadjah Mada Yogyakarta, Prof. Dr. Edward O.S. Hiariej, S.H, M.H., dalam wawancara via email dengan peneliti, menyatakan bahwa:

"Tindakan yang dilakukan oleh Anggota Polresta Yogyakarta seperti hasil penelitian di atas dapat dikategorikan sebagai diskresi dengan tujuan untuk dapat menciptakan suatu keadaan yang kondusif dan mendatangkan manfaat yang lebih besar, dari pada harus melaksanakan aturan sesuai ketentuan terkait penyampaian pendapat di muka umum" (Jabawan Prof Dr. Edward O.S. Hiariej, S.H., M.H., 11 Mei 2015).

Diskresi merupakan tindakan yang dilakukan oleh anggota Polisi berdasarkan penilaiannya sendiri yang bersumber dari pengetahuan yang dimiliki oleh sang Polisi. Peneliti berpendapat bahwa diskresi akan mempunyai hasil yang maksimal apabila Anggota Polisi mempunyai pengetahuan dan pemahaman yang cukup dalam hal: (1) Aturanaturan atau ketentuan yang berlaku. Anggota Polisi wajib mengetahui secara pasti ketentuanketentuan yang berlaku terutama aturan-aturan terkait tantangan yang sering dihadapinya, sehingga yang bersangkutan juga mengetahui aturan mana yang akan dilanggarnya dan aturan yang tetap diikutinya; (2) Situasi lingkungan atau tempat tantangan yang dihadapinya dalam hal ini terkait budaya atau norma yang berlaku. Hukum bukan saja aturan-aturan yang tertulis dan diundangkan saja, tetapi kebiasaan-kebiasaan yang dilakukan masyarakat setempat bisa disebut juga sebagai hukum; (3) Pertimbangan untung atau rugi dalam penerapan diskresi, dalam hal ini yang dimaksud dengan keuntungan atau kerugian adalah bagi kepentingan umum, institusi, dan pribadi Anggota Polisi; (4) Batasan dalam penerapan diskresi, yaitu Anggota Polisi harus menetapkan batasan terkait diskresi yang diterapkan, sampai batasan yang bagaimana diskresi tersebut berlaku dan menyiapkan tindakan lain dalam hal ini tindakan sesuai aturan yang berlaku apabila batasan tersebut telah terlampaui.

\section{Prosedur Penanganan Unjuk Rasa}

Peraturan Kapolri Nomor 7 Tahun 2012 tentang Tata Cara Penyelenggaraan 
Pelayanan, Pengamanan dan Penanganan Perkara Penyampaian Pendapat di Muka Umum adalah sebagai berikut:

Pertama, Penyampaian pemberitahuan kegiatan kepada kepolisian setempat (surat pemberitahuan kegiatan). Maksud dari kepolisian setempat di sini yaitu: (1) Apabila aksi dilaksanakan dalam area yang meliputi dua provinsi atau massa aksi berasal dari beberapa wilayah provinsi, maka pemberitahuan disampaikan kepada Mabes Polri (Bidang Pelayanan Masyarakat Badan Intelijen Keamanan Mabes Polri); (2) Apabila aksi dilaksanakan di beberapa/lintas kabupaten/ kota dan massa aksi berasal dari beberapa kota/ kabupaten maka pemberitahuan disampaikan kepada Kepolisian Daerah (Polda) dalam hal ini adalah Seksi Pelayanan Administrasi Direktorat Intelkam Polda; (3) Apabila aksi dilaksanakan dalam satu lingkup wilayah kabupaten/kota dan massa aksi berasal dari beberapa wilayah kecamatan setempat, maka pemberitahuan disampaikan kepada Kepolisian Resort (Polres/Polresta) dan diterimakan di Satuan Intelijen Keamanan Polres/Polresta; (4) Apabila aksi dilaksanakan dalam lingkup wilayah kecamatan dan massa aksi berasal dari kecamatan dimaksud, maka pemberitahuan disampaikan kepada Polsek setempat (unit pelayanan Polsek).

Kedua, penerimaan surat pemberitahuan oleh Petugas Kepolisian dan dilakukan: (1) Penelitian kebenaran, kelengkapan dan keterangan dalam surat pemberitahuan; (2) Penelitian identitas penanggung jawab aksi (KTP/SIM/Paspor);

Ketiga, Penerbitan STTP (Surat Tanda Terima Pemberitahuan) oleh Kepolisian dengan tembusan satuan Kepolisian terkait dan pemilik/lokasi tempat obyek/sasaran aksi.
Pada tingkat Mabes Polri, STTP ditandatangani oleh Kepala Bidang Pelayanan Masyarakat (Kabid Yanmas) Badan Intelijen Keamanan (Baintelkam) Polri atas nama Kepala Badan Intelijen Keamanan Polri, pada tingkat Provinsi ditandatangani oleh Direktur Intelijen Keamanan atau Wakil Direktur Intelijen Keamanan Polda, pada tingkat kabupaten/kota ditandatangani oleh Kapolres atau Wakapolres atau Kasat Intelkam atas nama Kapolres, dan pada tingkat kecamatan ditandatangani oleh Kapolsek atau Wakapolsek;

Keempat, Koordinasi antara Kepolisian denganpenanggungjawab aksiterkaitpelayanan dan pengamanan aksi demi kelancaran dan ketertiban aksi. Tahapan ini membahas halhal yang akan disepakati antara penanggung jawab aksi dengan pihak kepolisian terkait aksi yang akan dilaksanakan, baik yang sudah terdapat dalam surat pemberitahuan maupun detail pelaksanaan kegiatan aksi yang akan dan seharusnya dilaksanakan, Kepolisian memberikan batasan-batasan, misalnya ketentuan dalam berpawai sehingga pengguna jalan lain tidak terlalu terganggu;

Kelima, Koordinasi dengan pemilik/ pimpinan instansi/lembaga yang menjadi sasaran aksi;

Keenam, Persiapan perangkat pengamanan aksi oleh Kepolisian, dengan tahapan: (1) Pembuatan analisis intelijen oleh Intelijen Keamanan sesuai tingkatannya; (2) Pembuatan rencana pengamanan dan penerbitan surat perintah pengamanan; (3) Rapat koordinasi internal Kepolisian yang membahas cara bertindak di lapangan; (4) Penyiapan sarana dan prasarana dalam kegiatan pengamanan yaitu: peralatan standar pengendalian massa; (5) Pemberian arahan kepada seluruh pasukan pengamanan. 
Legowo Saputro -- Diskresi Anggota Kepolisian Negara Republik Indonesia Dalam Penanganan Aksi Unjuk Rasa Dan Implikasinya Terhadap Ketahanan Wilayah

(Studi Di Kepolisian Resort Kota Yogyakarta)

\section{Unjuk Rasa di Kota Yogyakarta}

Pelaku unjuk rasa di Kota Yogyakarta didominasi oleh mahasiswa. Berdasarkan tabel 3, mahasiswa selalu menjadi unsur yang dominan dalam setiap kegiatan aksi unjuk rasa. Aksi unjuk rasa oleh mahasiswa di Kota Yogyakarta pada Tahun 2011 sebanyak 107 kali atau 65\% dari total 165 kali unjuk rasa yang dilakukan pada tahun tersebut, kemudian di Tahun 2012 sebanyak 92 kali atau 53\% dari 174 total unjuk rasa yang dilakukan, 81 kali atau 48\% di Tahun 2013 dari 169 kali unjuk rasa yang dilakukan, dan 94 kali atau 55\% dari 172 kali unjuk rasa yang dilakukan secara keseluruhan di Tahun 2014. Jika dirataratakan, dalam kurun waktu empat tahun dari Tahun 2011 hingga 2014, mahasiswa melakukan unjuk rasa sebanyak 94 kali atau sekitar 54\% dari rata-rata unjuk rasa yang dilakukan dalam kurun waktu tersebut.

Berdasakan motif atau kepentingannya, unjuk rasa dapat dibedakan menjadi motif ekonomi, politik, sosial budaya, serta hukum dan keamanan, sebagaimana tabel 4.

Berdasarkan data tersebut, terlihat bahwa aksi unjuk rasa atas dasar motif ekonomi dari Tahun 2011-2014 menduduki peringkat tertinggi yaitu 184 kali atau 27,1\% kemudian disusul oleh unjuk rasa bermotifkan sosial budaya sebanyak 181 kali atau 26,6\%, motif politik sebanyak 151 kali atau 22,2\% dan motif lain sebanyak 21 kali atau 3,1\%. Unjuk rasa pada Tahun 2011 terbanyak bermotifkan sosial budaya, saat itu marak unjuk rasa penolakan

Tabel. 3

Data Unjuk Rasa di Kota Yogyakarta Berdasarkan Pelaku

\begin{tabular}{|c|c|c|c|c|c|c|c|c|c|c|c|c|}
\hline \multirow{2}{*}{ No } & Tahun & Mahasiswa & Pelajar & Guru & $\begin{array}{c}\text { Karyawan/B } \\
\text { uruh }\end{array}$ & $\begin{array}{c}\text { LSM/ } \\
\text { Ormas }\end{array}$ & Wartawan & Masy & Parpol & Pedagang & Lainna & Jumlah \\
\hline 1 & 2011 & 107 & 1 & 0 & 6 & 34 & 1 & 13 & 1 & 2 & 1 & 165 \\
\hline 2 & 2012 & 92 & 1 & 0 & 4 & 49 & 2 & 4 & 3 & 6 & 13 & 174 \\
\hline 3 & 2013 & 81 & 1 & 1 & 10 & 48 & 4 & 8 & 3 & 4 & 9 & 169 \\
\hline 4 & 2014 & 94 & 0 & 0 & 7 & 53 & 1 & 6 & 1 & 3 & 7 & 172 \\
\hline Jumlah & $\mathbf{3 7 4}$ & $\mathbf{3}$ & $\mathbf{1}$ & $\mathbf{2 7}$ & $\mathbf{1 8 4}$ & $\mathbf{8}$ & $\mathbf{3 1}$ & $\mathbf{8}$ & $\mathbf{1 5}$ & $\mathbf{3 0}$ & $\mathbf{6 8 0}$ \\
\hline
\end{tabular}

Sumber: Sat Intelkam Polresta Yogyakarta Tahun 2014.

Tabel 4

Data Unjuk Rasa di Kota Yogyakarta Berdasarkan Motif

\begin{tabular}{|c|c|c|c|c|c|c|c|}
\hline \multirow{2}{*}{ No } & \multirow{2}{*}{ Tahun } & \multicolumn{5}{|c|}{ Motif } & \multirow{2}{*}{ Jumlah } \\
\cline { 3 - 8 } & Politik & Ekonomi & Sosbud & $\begin{array}{c}\text { Hukum/Kea } \\
\text { manan }\end{array}$ & Lainnya & \\
\hline 1 & 2011 & 54 & 15 & 56 & 34 & 6 & 165 \\
\hline 2 & 2012 & 18 & 84 & 37 & 31 & 4 & 174 \\
\hline 3 & 2013 & 31 & 50 & 42 & 43 & 3 & 169 \\
\hline 4 & 2014 & 48 & 35 & 46 & 35 & 8 & 172 \\
\hline \multicolumn{2}{|c|}{ Jumah } & $\mathbf{1 5 1}$ & $\mathbf{1 8 4}$ & $\mathbf{1 8 1}$ & $\mathbf{1 4 3}$ & $\mathbf{2 1}$ & 680 \\
\hline
\end{tabular}

Sumber: Sat Intelkam Polresta Yogyakarta Tahun 2014. 
Undang-undang Sistem Pendidikan Nasional, komersialisasi kampus serta aksi solidaritas untuk Timur Tengah. Selanjutnya di tahun yang sama, unjuk rasa bermotif politik juga tidak jauh berbeda jumlahnya dengan motif sosial budaya karena saat itu Kota Yogyakarta dalam suasana pemilihan kepala daerah, serta merupakan titik awal penolakan terhadap RUU Keistimewaan DIY, meskipun telah diwacanakan pada akhir Tahun 2010 yang di dalamnya memuat opsi pemilihan untuk gubernur dan wakil gubernur.

Tahun 2012, unjuk rasa bermotif ekonomi paling banyak dilakukan yaitu 84 kali atau 48\%, dengan 44 kalinya merupakan unjuk rasa menolak kenaikan harga BBM. Saat itu pemerintah berencana untuk menaikkan harga BBM, meskipun rencana tersebut akhirnya batal dilaksanakan. Unjuk rasa bermotif ekonomi menjadi yang terbanyak kembali di Tahun 2013, yaitu di Bulan Juni pemerintah kembali mewacanakan kenaikan harga BBM, dan hal itu benar dilaksanakan oleh pemerintah (BPS, 2013).

\section{Kendala Penerapan Diskresi Dalam Penanganan Aksi Unjuk Rasa}

Pertama, Pemahaman anggota. Diskresi oleh Anggota Polresta Yogyakarta dipahami secara beragam yang disebabkan oleh pengalaman dinas masing-masing anggota Polisi serta pengetahuan yang dimilikinya tentang hukum dan peraturan perundangundangan. Pasal 18 Ayat 1 Undangundang Nomor 2 Tahun 2002 bahwa dalam melaksanakan tugas dan kewenangannya untuk kepentingan umum, Polisi dapat bertindak menurut "penilaiannya sendiri". Frasa "penilaiannya sendiri” tersebut diartikan sebagai kemampuan Anggota Kepolisian
Negara Republik Indonesia, yang selanjutnya disebut sebagai "Polisi”, untuk memahami apa yang sedang terjadi dan aturan-aturan apa saja yang melingkupinya, menganalisisnya serta selanjutnya mewujudkannya dalam bentuk tindakan. Dengan demikian, basis diskresi merupakan penilaian dari individu, tergantung siapa individu tersebut.

Anggota Polisi yang berpangkat bintara dan bertugas pada fungsi operasional akan lebih paham terhadap diskresi dalam tindakannya, dari pada anggota Polisi yang bertugas pada fungsi pembinaan. Anggota Polisi yang lebih lama berdinas/bertugas akan lebih memahami tentang diskresi dari pada Anggota Polisi yang baru beberapa bulan berdinas. Polisi yang bertugas pada fungsi operasional pun memiliki tingkat pemahaman yang berbeda, misalnya Polisi lalu lintas, reskrim, intelijen, dan binmas, tingkat pemahamannya tentang diskresi lebih tinggi atau lebih matang dari pada rekan mereka yang bertugas pada fungsi sabhara.

Tingkat intelektualitas dan pengetahuan anggota Polresta Yogyakarta berbeda-beda, yang disebabkan oleh tingkat pendidikan dan pengalaman yang diperoleh oleh anggota yang bersangkutan. Perbedaan tersebut berpengaruh terhadap tingkat pemahaman terkait diskresi kepolisian dan dengan hal itu berakibat langsung terhadap pelaksanaan tugas di lapangan, terutama bagi anggota yang bertugas pada fungsi operasional, namun demikian tidak jarang pula kewenangan diskresi diambil alih langsung, dalam hal ini dilakukan oleh Kapolresta atau secara hirarki bertindak atas nama Kapolresta dalam bentuk perintah kepada anggota Polisi baik dari fungsi operasional, ataupun pembinaan, baik Polisi lalu lintas, intel, reskrim, binmas ataupun sabhara, untuk penanganan suatu perkara. 
Legowo Saputro -- Diskresi Anggota Kepolisian Negara Republik Indonesia Dalam Penanganan Aksi Unjuk Rasa Dan Implikasinya Terhadap Ketahanan Wilayah

(Studi Di Kepolisian Resort Kota Yogyakarta)

Kedua, Kekuatan Sumber Daya Manusia. Pertimbangan dari penerapan diskresi oleh Anggota Polri adalah demi kepentingan umum dan manfaat yang lebih besar yaitu ketertiban umum. Namun dapat saja, diskresi yang berupa kebijaksanaan dalam bentuk toleransi pada aksi unjuk rasa tersebut tidak diartikan oleh pengunjuk rasa sebagai bentuk penghargaan terhadap kemerdekaan menyampaikan pendapat di muka umum, tetapi sebaliknya sebagai bentuk kelemahan ataupun pembiaran oleh Polisi, sehingga perilaku pengunjuk rasa justru semakin tidak dapat dikendalikan. Hal ini terutama terjadi apabila massa pengunjuk rasa berjumlah besar dan petugas Polisi terlihat lebih sedikit.

Rasio jumlah Polisi dengan penduduk Kota Yogyakarta berdasarkan data di atas yaitu $1: 240$, artinya bahwa satu orang Polisi melayani 240 penduduk, dan hal tersebut sudah sangat “ideal” daripada rasio ideal yang di sampaikan Jenderal Polisi Drs. Sutarman ataupun ketentuan PBB yaitu 1 : 300. Angka rasio tersebut ditentukan sebagai patokan tingkat efektivitas Polisi dalam pelaksanaan tugas melayani masyarakat, semakin kecil perbandingannya, semakin baik tingkat pelayanannya. Namun apabila melihat kembali kenyataan seperti di Polresta Yogyakarta, terkait dengan penyelenggaraan pelayanan, pengamanan dan penanganan unjuk rasa, angka perbandingan tersebut masih jauh dari yang diharapkan (tabel 5).
Menurut peneliti, penghitungan rasio oleh BPS ataupun oleh Polri saat ini menggunakan data jumlah Polri secara keseluruhan pada suatu wilayah dan membandingkannya dengan jumlah penduduk yang beridentitaskan pada wilayah itu. Perhitungan rasio tersebut tidak melihat kondisi riil di lapangan, yaitu jumlah Polisi yang bertugas setiap harinya di lapangan dalam hal ini Polisi yang benar-benar memberikan pelayanan kepada masyarakat. Karena penugasan Polisi menurut fungsinya terbagi menjadi dua, yaitu Polisi pada fungsi pembinaan, yaitu Polisi dengan penugasan administrasi perkantoran, pengawasan, perencanaan dan keuangan, dan sumber daya manusia. Tugas Polisi ini melayani Polisi lain dan bertugas sesuai fungsinya, pada beberapa bidang diawaki oleh PNS Polisi. Selanjutnya fungsi operasional, adalah Polisi yang bertugas melakukan tugas pelayanan kepada masyarakat dalam hal perijinan, penerbitan SKCK, penerbitan SIM, pembinaan masyarakat, pengamanan kegiatan, patroli, penjagaaan dan pengawalan, penyelidikan dan penyidikan perkara pidana. Polisi pada fungsi operasional dalam penugasannya diatur dengan sistem 3 shift/piket dengan lama bertugas 12 jam. Hal inilah yang menurut peneliti di luar dari perhitungan tersebut.

Selanjutnya berkaitan dengan penduduk, BPS atau Polri dalam perhitungan rasio

Tabel 5

Rasio Jumlah Polisi dengan Penduduk Kab/Kota di Provinsi DIY Tahun 2013

\begin{tabular}{clrrrrc}
\hline No & \multicolumn{1}{c}{ Kab/Kota } & Polisi Laki-Laki & Polisi Wanita & Polisi & Penduduk & Rasio \\
\hline 1. & Kulon Progo & 995 & 30 & 1.025 & 401.450 & $1: 385$ \\
2. & Bantul & 1.445 & 70 & 1.515 & 955.015 & $1: 619$ \\
3. & Gunung Kidul & 872 & 19 & 890 & 693.524 & $1: 837$ \\
4. & Sleman & 1.914 & 74 & 1.988 & 1.147 .037 & $1: 577$ \\
5. & Yogyakarta & 1.712 & 60 & 1.772 & 397.828 & $1: 240$ \\
6. & Mapolda DIY & 2.586 & 222 & 2.808 & - & - \\
\hline & Total & 9.524 & 475 & 9.998 & 3.594 .854 & $1: 371$ \\
\hline
\end{tabular}

Sumber: BPS, Statistik Politik dan Keamanan DIY 2013 hal: 10. 
menggunakan jumlah penduduk hasil sensus, seharusnya BPS atau Polri juga memperhitungkan penduduk di luar sensus namun berada pada wilayah itu. Seperti halnya Kota Yogyakarta sebagai Kota Wisata, tentu saja banyak wisatawan yang berada di Kota Yogyakarta setiap harinya. Di samping itu, Kota Yogyakarta juga menjadi tempat bekerjanya orang-orang dari luar kota di wilayah Provinsi DIY maupun Jawa Tengah yang setiap harinya beraktivitas di Kota Yogyakarta (khususnya siang hari). Selain hal tersebut, Kota Yogyakarta disebut sebagai Kota Pelajar, tentu saja banyak pelajar atau mahasiswa yang tinggal menetap di Kota Yogyakarta selama masa studinya. Sesuai data, terdapat 87 asrama mahasiswa yang ada di Kota Yogyakarta dengan jumlah penghuni lebih kurang 1.215 jiwa (BPS, 2013).

Berdasarkan hal tersebut rasio jumlah Polisi dengan jumlah penduduk dapat diperhitungkan sesuai dengan kondisi yang ada pada kenyataannya. Atau dengan rumus sederhana dapat dijabarkan sebagai berikut:

$$
\begin{aligned}
\mathrm{R} & =\mathrm{Py}: \mathrm{P} \\
\mathrm{Py} & =(\mathrm{Po}-(\mathrm{Ps}+\mathrm{Pld}+\mathrm{Pc})) \\
\mathrm{P}= & \mathrm{Psn}+\mathrm{k}+\mathrm{p} / \mathrm{m}+\mathrm{w} \\
\mathrm{R} \quad: & \text { Rasio } \\
\mathrm{Po} \quad: & \text { Jumlah keseluruhan Polisi di suatu } \\
& \text { wilayah } \\
\text { Ps } \quad \text { Jumlah Polisi bertugas pada staf/ } & \text { pembinaan }
\end{aligned}
$$

Pld : Jumlah Polisi yang selesai berdinas dalam satu hari (lepas dinas)

Pc : Jumlah Polisi yang akan bersiap untuk berdinas pada shift berikutnya

Py : Jumah Polisi yang melaksanakan pelayanan

P : Jumlah Riil Penduduk suatu wilayah
Psn : Jumlah Penduduk sesuai sensus

$\mathrm{k}$ : pekerja/karyawan dari luar kota

$\mathrm{p} / \mathrm{m}$ : jumlah pelajar dan mahasiswa dari luar kota

w : jumlah wisatawan

Ketiga, Aturan Pertanggungjawaban Diskresi. Diskresi dalam penanganan aksi unjuk rasa yang diterapkan Anggota Polresta Yogyakarta selama kurun waktu penelitian dan data yang diperoleh, selalu menggunakan pendekatan secara persuasif dan dengan tindakan pencegahan, namun sebenarnya, diskresi Kepolisian tidak selalu dengan model pendekatan tersebut, dapat saja dengan tindakan tegas menggunakan pendekatan kekuatan atau power. Tindakan tegas dengan menggunakan kekuatan tidak dilakukan, karena pertanggungjawaban diskresi sifatnya mengikat secara personal dan hal tersebut menjadi pertimbangan sendiri oleh Anggota Polresta Yogyakarta, yaitu bahwa apabila dalam menggunakan kewenangan tersebut melanggar peraturan perundang-undangan atau melanggar KEPP dan atau ketentuan pidana, maka sanksi akan dijatuhkan secara personal, meskipun tetap saja melalui proses penelitian dalam sidang Komisi KEPP. Sanksi secara personal inilah yang dianggap menakutkan bagi Anggota Polresta Yogyakarta.

Keempat, Masyarakat/Lingkungan. Penerapan diskresi dalam penanganan aksi unjuk rasa yang dilakukan Anggota Polresta Yogyakarta dengan pendekatan persuasif selama ini memang terlihat terlalu lunak, hampir tidak ada tindakan tegas sesuai ketentuan yang diterapkan, hal ini sebagaimana disampaikan tokoh masyarakat, Romo Suhud yang juga ketua Paksi Katon bahwa: 
Legowo Saputro -- Diskresi Anggota Kepolisian Negara Republik Indonesia Dalam Penanganan Aksi Unjuk Rasa Dan Implikasinya Terhadap Ketahanan Wilayah

(Studi Di Kepolisian Resort Kota Yogyakarta)

"Penanganan aksi unjuk rasa yang dilakukan oleh Polresta Yogyakarta selama ini cenderung tidak tegas dan bisa dikatakan terlalu lunak, padahal apabila dilihat, banyak pelanggaran yang dilakukan oleh massa aksi, seperti melakukan pembakaran ban dan membuat macet arus lalu lintas dengan menutup sebagian besar jalan. Menurut Romo Suhud hal tersebut apabila tidak ditindak maka seolah-olah akan menjadi pembenaran oleh massa aksi dalam setiap melakukan aksi unjuk rasa. Pimpinan yang berada di lapangan juga terlihat mendukung tindakan yang selama ini dilakukan dan hal tersebut tergantung dari pimpinannya, sehingga apa yang dilakukan oleh anggota di lapangan menyesuaikan saja perintah pimpinan. Tapi setidaknya, seharusnya setiap anggota Polisi apabila menemukan pelanggaran, paling tidak harus berani menegur dan sebisa mungkin melakukan tindakan tegas. Bekal keberanian ini yang masih kurang dimiliki oleh pimpinan Polresta Yogyakarta maupun seluruh anggota di lapangan" (Wawancara di kediaman Romo Suhud tanggal 11 April 2015).

Kelima, Pengunjuk Rasa. Tindakan pengamanan terhadap unjuk rasa yang dilakukan oleh Anggota Polresta Yogyakarta ditanggapi beragam oleh pengunjuk rasa, ada yang menyatakan bahwa konsep pengamanan unjuk rasa sudah tepat, namun ada pula yang menganggap bahwa konsep pengamanan yang di lakukan oleh Polresta Yogyakarta merupakan bentuk kesengajaan Polisi untuk membenturkan pengunjuk rasa dengan masyarakat. Hal tersebut seperti pernyataan Abdurahman, Mahasiswa Universitas Cokroaminoto, kordum Komite Perjuangan Rakyat Yogyakarta (KPRY), saat melakukan aksi dalam rangka hari HAM sedunia yang menyatakan bahwa Polisi dalam pengamanan aksi justru memprovokasi supaya terjadi benturan dengan masyarakat atau pengguna jalan lain. Menurutnya seharusnya Polisi melakukan pengamanan dengan mengatur lalu lintas, anggapannya, selama ini Polisi seolah-olah memang sengaja membenturkan pengunjuk rasa dengan masyarakat.

\section{Implikasi Diskresi Anggota Kepolisian Resort Kota Yogyakarta dalam Penanganan Aksi Unjuk Rasa terhadap Ketahanan Wilayah}

Diskresi Anggota Kepolisian Resort Kota Yogykarta dalam penanganan aksi unjuk rasa pada dasarnya dipahami sebagai tindakan Anggota Polri untuk melakukan atau tidak melakukan tindakan atau melakukan tindakan lain terhadap pelanggaran yang dilakukan oleh pengunjuk rasa atas ketentuan yang berlaku terkait kemerdekaan menyampaikan pendapat di muka umum. Dalam tindakan diskresi tersebut terdapat unsur yang bisa disebut dengan "mentoleransi” atau lebih kasarnya disebut "membiarkan" pelanggaran tetap terjadi. Hal tersebut apabila berlangsung terus menerus disertai dengan pengabaian terhadap eskalasi pelanggaran yang dilakukan oleh Polisi, maka oleh masyarakat pelanggaran tersebut akan dianggap sebagai hal yang dapat dibenarkan dan dapat dilakukan oleh masyarakat yang lain, meskipun sebenarnya tindakan diskresi tersebut dilakukan sebagai upaya Polresta Yogyakarta dalam rangka melaksanakan tugasnya memelihara keamanan dan ketertiban umum serta sebagai pelindung, pengayom, dan pelayan masyarakat, bukan dimaksudkan sebagai pembiaran terhadap pelanggaran yang terjadi.

Keadaan tersebut apabila berlangsung dalam waktu yang lama akan merubah pandangan masyarakat tentang apa yang sebenarnya tidak boleh dilakukan atau sesuai 
ketentuan disebut sebagai pelanggaran, menjadi hal yang dapat dilakukan dan dianggap benar. Hal tersebut sebagaimana disampaikan AKP Rahmat Yulianto, S.H, M.Si, yang menyatakan bahwa:

"Penanganan aksi unjuk rasa dalam keadaan tertentu, diskresi kepolisian dapat diterapkan, namun diskresi membutuhkan prasyarat atau batasan, sehingga diskresi yang diterapkan tidak berubah atau dianggap sebagai pembiaran, dan apabila keadaan tersebut berlangsung terus-menerus dalam setiap aksi unjuk rasa dan dalam waktu yang lama, maka akan timbul kekaburan terkait ketentuan yang menjadi larangan dalam unjuk rasa yang pada akhirnya akan menjadi bumerang bagi Polisi sendiri berupa pelanggaran yang dilakukan akan terus saja dilakukan dan rendahnya penghormatan masyarakat terhadap ketentuan hukum, serta buruknya citra Polisi dalam penanganan aksi unjuk rasa" (Wawancara di Polda DIY tanggal 6 Januari 2015).

Diskresi Anggota Kepolisian Resort Kota Yogyakarta dalam penanganan aksi unjuk rasa juga berimplikasi positif terhadap ketahanan wilayah dalam lima aspek gatra dinamis sebagai berikut:

Pertama, Aspek Ideologi. Diskresi kepolisian yang diterapkan oleh Anggota Polresta Yogyakarta dalam penanganan aksi unjuk rasa untuk memberi ruang yang cukup terhadap pelaku unjuk rasa dengan berbagai macam tujuan dan latar belakang, meskipun dalam pelaksanaan unjuk rasa tanpa disertai pemberitahuan dan berbagai macam pelanggaran lain dalam batas kewajaran. Tindakannya merupakan wujud kesadaran bahwa perbedaan pandangan merupakan hal yang wajar dan merupakan suatu upaya untuk menjaga agar dinamika kehidupan berdemokrasi dan heterogenitas yang ada di Indonesia tidak mengarah ke dalam perpecahan dan mengancam keutuhan bangsa, selain itu tindakan Polresta Yogyakarta dengan meminimalkan penggunaan peralatan standar pengendalian massa dalam penanganan aksi unjuk rasa yang bertujuan untuk meminimalisir bentrokan dengan pelaku unjuk rasa merupakan penghargaan terhadap nilai kemanusiaan dan penghormatan terhadap HAM dan keadilan.

Diskresi Polisi juga secara tidak langsung berkontribusi dalam memberikan pelajaran tentang toleransi. Penjelasan atas hal tersebut yaitu saat terjadi unjuk rasa yang dalam satu hari lebih dari satu kelompok dan masingmasing kelompok tersebut menolak untuk bergabung meskipun dengan tema yang sama, antar kelompok tersebut saling berkoordinasi dan menunggu untuk bergantian menempati tempat yang diinginkan, mereka tidak saling berebut apalagi berbenturan. Hal tersebut merupakan kontribusi diskresi dalam upaya menjaga nilai-nilai luhur bangsa Indonesia seperti yang terdapat dalam jiwa Pancasila, khususnya dalam hal hormat menghormati dan bertoleransi dalam perbedan yang ada dan memberikan ruang yang cukup agar perbedaan tersebut tersampaikan tanpa ada tekanan ataupun intervensi dari pihak manapun.

Kedua, Aspek Politik. Diskresi dalam penanganan aksi unjuk rasa oleh Polresta Yogyakarta, berdasarkan pengamatan dan analisis peneliti menghasilkan dua wujud dari ketahanan politik wilayah, yaitu pertama hak politik masyarakat dalam hal ini pengunjuk rasa tetap diperolehnya dan yang kedua hubungan antara pemerintah dalam hal ini Polisi dengan masyarakat dan unsur terkait utamanya sasaran aksi unjuk rasa seperti DPRD, Kejaksaan, dan Pemerintahan Daerah 
Legowo Saputro -- Diskresi Anggota Kepolisian Negara Republik Indonesia Dalam Penanganan Aksi Unjuk Rasa Dan Implikasinya Terhadap Ketahanan Wilayah

(Studi Di Kepolisian Resort Kota Yogyakarta)

(Pemkot Yogyakarta) terjalin dengan baik. Koordinasi dan komunikasi yang dilakukan oleh Polisi baik terhadap pengunjuk rasa, masyarakat, Anggota DPRD, walikota dan unsur pemerintahan yang lain merupakan salah satu bentuk diskresi. Komunikasi dan koordinasi yang dilakukan Polisi dengan pengunjuk rasa sebelum pelaksanaan aksi unjuk rasa menjadi tugas Satintelkam Polresta Yogyakarta. Dalam koordinasinya dibahaslah serta disepakati konsep pelaksanaan unjuk rasa dengan tetap mengedepankan ketertiban namun maksud dari unjuk rasa dapat tercapai juga, sehingga informasi serta tuntutan tersampaikan, baik kepada masyarakat maupun sasaran aksi. Selanjutnya, dalam pelaksanaan aksi unjuk rasa terjadi lagi kontak antara Polisi dengan pengunjuk rasa serta masyarakat. Koordinasi kembali dilakukan oleh Polisi dan pengunjuk rasa, dalam koordinasi tersebut dibahas lagi rute, lama unjuk rasa serta himbauan kepada pengunjuk rasa untuk tetap berlaku tertib dan menghormati masyarakat lain.

Ketiga, Aspek Ekonomi. Kegiatan ekonomi pada tingkat wilayah merupakan seluruh kegiatan pemerintah dan masyarakat dalam mengelola wilayah dalam hal faktor produksi yaitu sumber daya alam, tenaga kerja, modal, teknologi, dan manajemen, dan distribusi barang serta jasa untuk kesejahteraan rakyat. Upaya meningkatkan ketahanan ekonomi adalah upaya meningkatkan kapasitas produksi dan kelancaran barang serta jasa secara merata ke seluruh wilayah. Ketahanan ekonomi terkait erat dengan ketahanan wilayah, karena pada dasarnya ketahanan ekonomi merupakan kemampuan masyarakat dalam memenuhi kebutuhannya dan kemampuan tersebut berbanding lurus dengan kesejahteraan masayarakat.
Unjuk rasa berdampak langsung dalam kegiatan ekonomi. Proses distribusi dapat terganggu apabila terjadi pemblokiran jalan, proses produksi terganggu apabila terjadi pemogokan buruh dan unjuk rasa yang disertai pengrusakan dan berakhir menjadi kerusuhan massa yang dapat menghentikan seluruh proses dalam kegiatan ekonomi dan bahkan berakibat kerugian dan kerusakan yang besar. Demikian pula apabila hal tersebut terjadi pada setiap unjuk rasa yang ada di Kota Yogyakarta, akan muncul sentimen negatif dari pelaku pasar dan wisatawan terhadap situasi yang terjadi di Kota Yogyakarta dan hal tersebut akan berdampak kepada nilai investasi di Kota Yogyakarta, penurunan jumlah wisatawan yang berkunjung ke Kota Yogyakarta, sehingga berakibat terhadap menurunnya pendapatan setiap pelaku usaha yang menggantungkan hidupnya pada sektor tersebut, dan yang lebih mengkhawatirkan, apabila situasi tersebut terjadi, dampaknya bukan hanya dialami oleh Kota Yogyakarta tetapi seluruh wilayah di DIY. Upaya yang dilakukan oleh Polresta Yogyakarta dalam penanganan aksi unjuk rasa dengan menerapkan diskresi, secara langsung berdampak pada terciptanya situasi yang kondusif, untuk mencegah tindakan anarkis dan kerusuhan massa.

Keempat, Aspek Sosial Budaya. Sebagai bagian dari masyarakat, hendaknya Polisi menyesuaikan di mana dia bertugas, seperti yang dikatakan Schneider bahwa, "Polisi mencerminkan masyarakat di mana mereka bertugas” (Tabah, 1991). Dalam kaitannya dengan aksi unjuk rasa di Kota Yogyakarta yang kebanyakan dilakukan oleh orang luar Yogyakarta, baik mahasiswa maupun pekerja/ buruh, tetapi mereka melakukannya di Kota Yogyakarta, sehingga sedapat mungkin, 
meskipun berbeda budaya dan adat istiadat, pelaksanaan unjuk rasa dilakukan dengan menghormati dan menghargai budaya Yogyakarta, begitupun dalam penanganannya oleh Polisi. Anggota Polresta Yogyakarta seharusnya wajib memahami budaya Yogyakarta, sehingga dalam pelaksanaan tugas didasari atas pemahamannya terhadap budaya yang tumbuh dan berkembang di Kota Yogyakarta, karena dalam setiap pelaksanaan tugas, Polisi selalu dihadapkan dengan tantangan, dan ketika melakukan intervensi, Polisi umumnya mengedepankan penilaian mereka terhadap situasi (Panggabean dan AliFauzi, 2014:17), yang hal tersebut tergantung bagaimana dan sejauh mana pengetahuan Polisi terhadap situasi (sosial budaya setempat).

Berdasarkan hal tersebut, Polresta Yogyakarta secara tidak langsung juga ikut serta dalam melestarikan budaya dan adat istiadat Yogyakarta serta memberikan kesempatan kepada masyarakat untuk ikut serta dalam usaha tersebut. Penanganan aksi unjuk rasa oleh Polresta Yogyakarta, menjaga dan mempertahankan aktivitas kehidupan dan penghidupan masyarakat Yogyakarta tetap normal, tanpa diliputi rasa takut akan terjadinya reaksi ataupun anarkisme massa yang berujung pada timbulnya korban jiwa maupun harta benda.

Kelima, Aspek Keamanan dan Ketertiban. Aksi unjuk rasa berdampak langsung terhadap situasi keamanan dan ketertiban masyarakat. Seaman-amannya atau setertibnya unjuk rasa pasti berpengaruh terhadap ketertiban umum, paling tidak berpengaruh pada kelancaran arus lalu lintas, begitupun yang terjadi di Kota Yogyakarta. Polresta Yogyakarta sadar bahwa dalam menciptakan keamanan dan ketertiban masyarakat bukan hanya menjadi tugasnya, melainkan di dalamnya terdapat keikutsertaan masyarakat, lingkungan, dan aparatur pemerintah yang lain. Penanganan aksi unjuk rasa oleh Polresta Yogyakarta dengan menerapkan diskresi Kepolisian dalam hal ini adalah dengan bertindak menurut penilaiannya sendiri demi kepentingan umum, melibatkan seluruh elemen masyarakat dan lingkungan sekitarnya. Tujuannya agar masyarakat terbiasa memberikan sikap terhadap aksi unjuk rasa yang terjadi, bukan mengajak untuk menentang atau mendukung aksi unjuk rasa tersebut, melainkan mengajak ikut andil dalam menciptakan situasi yang aman dan tertib serta damai selama unjuk rasa berlangsung.

\section{SIMPULAN}

Tindakan Anggota Kepolisian Resort Kota Yogyakarta dalam penanganan aksi unjuk rasa dapat dikatakan sebagai diskresi yaitu tindakan persuasif dan pencegahan dengan memperbolehkan aksi unjuk rasa tetap berlangsung meskipun tanpa surat pemberitahuan dan pelaksanaannya melakukan pelanggaran. Tindakan tersebut dalam pelaksanaannya menemui kendala terutama terkait sumber daya manusia Polisi berupa rendahnya pemahaman Anggota Polresta Yogyakarta dan berakibat pada kualitas diskresi yang dilakukan, sehingga justru dikatakan sebagai “pembiaran” dan pemahaman tersebut menyebabkan rasa takut untuk bertindak. Efek deterrence diskresi ataupun keberadaan Polisi terhadap pengunjuk rasa tidak terlalu berdampak, bahkan cenderung memicu pengunjuk rasa untuk bertindak dan berperilaku yang mengganggu ketertiban dan kepentingan umum, karena jumlah kekuatan Polisi yang tidak memadai. Masyarakat menganggap penanganan aksi unjuk rasa 
Legowo Saputro -- Diskresi Anggota Kepolisian Negara Republik Indonesia Dalam Penanganan Aksi Unjuk Rasa Dan Implikasinya Terhadap Ketahanan Wilayah

(Studi Di Kepolisian Resort Kota Yogyakarta)

oleh Polresta Yogyakarta terlalu lunak dan memberikan kesan bahwa pelanggaran oleh pelaku unjuk rasa sebagai hal yang benar dan akan diulangi secara terus menerus. Pengunjuk rasa menganggap tindakan diskresi tersebut sebagai kesengajaan yang dilakukan untuk membenturkan pengunjuk rasa dengan masyarakat.

Penanganan aksi unjuk rasa oleh Polresta Yogyakarta berdampak positif terhadap stabilitas wilayah, yaitu tetap terselenggaranya aktivitas berbagai macam aspek kehidupan masyarakat Kota Yogyakarta, hal tersebut apabila dilihat dari sudut pandang tidak terjadinya bentrokan antara Polisi, masyarakat dan pengunjuk rasa. Berdampak negatif pula apabila dilihat dari sudut pandang supremasi hukum, yakni tindakan Anggota Kepolisian Resort Kota Yogyakarta dianggap sebagai lemahnya aparat penegak hukum yaitu Polri atau dalam lingkup wilayah disebut ketidakberdayaan pemerintah dalam mengupayakan tertib dan tegaknya hukum.

Agar diskresi yang diterapkan oleh Anggota Kepolisian Resort Kota Yogyakarta dapat berdampak maksimal bagi ketahanan wilayah, maka terdapat rekomendasi yang diajukan yaitu: (1) Pelatihan dan pendidikan terkait permasalahan dalam pelaksanaan tugas Anggota Polri. Polri perlu membentuk suatu badan khusus untuk penelitian dan pengembangan bagi Institusi Polri, sehingga aturan ataupun ketentuan serta kebijakan yang dikeluarkan oleh Polri lahir dari proses secara ilmiah, sesuai karekteristik wilayah yang berbeda-beda; (2) Penambahan jumlah Anggota Polri yang disesuaikan dengan karakteristik wilayah; (3) Penjelasan tentang diskresi dalam hal ketertiban umum agar dikomunikasikan kepada masyarakat, sehingga tidak timbul persepsi negatif dari masyarakat terkait tindakan yang dilakukan oleh Polisi.

\section{DAFTAR PUSTAKA}

Aaron, Thomas J., 1960. The Control of Police Discretion. Illinois, Charles, C. Thomas, Springfield.

BPS, Statistik Politik dan Keamanan DIY 2013, Badan Pusat Statistik Daerah Istimewa Yogyakarta.

Faal, M., 1991, Penyaringan Perkara Pidana oleh Kepolisian (Discretion Kepolisian). Jakarta: P.T. Paradnya Paramitha.

Panggabean, R., dan Ali-Fauzi, I., 2014. Pemolisian Konflik Keagamaan di Indonesia. Jakarta: PUSAD Paramadina.

Ridwan, 2014. Diskresi dan Tanggung Jawab Pemerintah. Yogyakarta: FH UII Press. Simorangkir, J.C.T., 1980. Kamus Hukum. Jakarta: Aksara Baru.

Sunardi, R.M., 2004, Pembinaan Ketahanan Bangsa Dalam Rangka Memperkokoh Keutuhan Negara Kesatuan Republik Indonesia, Jakarta: P.T. Katernita Adidarma.

Tabah, A. 1991. Menatap Dengan Mata Hati Polisi Indonesia. Jakarta: P.T. Gramedia Pustaka Utama.

\section{Undang-Undang dan Peraturan}

1. UU No. 9 Tahun 1998, Tentang Kemerdekaan Menyampaikan Pendapat Di Muka Umum.

2. UU No. 2 Tahun 2002 Tentang Kepolisian Negara Republik Indonesia.

3. Peraturan Kapolri No. 16 Tahun 2006 Tentang Pedoman Pengendalian Massa.

4. Peraturan Kapolri No. 7 Tahun 2012 Tentang Tata Cara Penyelenggaraan, 
Pelayanan, Pengamanan, Dan Penanganan Perkara Penyampaian Pendapat Di Muka Umum.

\section{Wawancara}

1. Aiptu Bambang Eko Lumaksono, 6 Januari 2015.

2. Aiptu Rubiyana, 11 Februari 2015.

3. Romo Suhud, 11 April 2015.
4. Prof. Dr. Edward O.S. Hiariej, S.H., M.H., 11 Mei 2015.

5. AKP Rahmat Yulianto, S.H., M.Si., 6 Januari 2015.

6. AKBP Agustinus Supriyanto

7. Bapak Yuke, Ketua DPRD DIY

8. Abdurrahman: Mahasiswa Universitas Cokroaminoto. 


\title{
DAMPAK PENGALIHAN FUNGSI LAHAN SAWAH PADA PRODUKSI PADI SAMPAI TAHUN 2018 DAN IMPLIKASINYA TERHADAP KETAHANAN PANGAN WILAYAH (Studi Di Kecamatan Jaten Kabupaten Karanganyar Propinsi Jawa Tengah)
}

\author{
Catur Setyo Wibowo \\ Kodam II/ Sriwijaya Palembang \\ Email : cswibowo@yahoo.co.id
}

\begin{abstract}
This research was aimed to estimated the extent of rice-field area that had been conversed into non-ricefield area in Jaten Sub-district up to 2018, to found out the factors causing the conversion, and to determined the impact of the land conversion for the production of rice towards the food security in Jaten Sub-district until 2018.

This was a descriptive research with quantitative methods. The data were described in the form of tables and graphs to described the impact of the land conversion and rice production toward the food security in Jaten Sub-district, Karanganyar Regency. The data was divided into two types; primary data and secondary data. Both of them were in the form of qualitative and quantitative data.

The results of the study showed that, the land conversion in Jaten Sub-district increased. It happened because of its strategic geographical location, the population growth, the need for housing, the industrial development, and the individual factor of the farmers. The depreciation of the rice-field significantly affected the reduction of rice production. It is proven by the result of statistical tests. The test showed the decreased amount of rice production up to 6309.8 tons, or about -2.9 percentyear. Based on the level of rice consumption in accordance with SUSENAS population in 2013, it was predicted that in 2020 people of Jaten Sub-district would get problem or lack of rice production.
\end{abstract}

\section{Keywords: Land Conversion, Rice Production, Regional Food Resilience}

\begin{abstract}
ABSTRAK
Tujuan yang ingin dicapai dalam penulisan tesis ini adalah untuk memperkirakan luasan lahan sawah yang telah dialih fungsikan ke non-sawah di Kecamatan Jaten sampai dengan tahun 2018, mengetahui faktor penyebab pengalihan fungsi lahan sawah di Kecamatan Jaten, mengetahui dampak pengalihan fungsi lahan sawah terhadap produksi padi dalam rangka ketahanan pangan di Kecamatan Jaten sampai tahun 2018.

Penelitian ini bersifat deskriptif dengan metode kuantitatif yang didiskripsikan dalam bentuk tabel dan grafik untuk menggambarkan dampak pengalihan fungsi lahan sawah terhadap produksi padi dalam rangka ketahanan pangan di wilayah Kecamatan Jaten Kabupaten Karanganyar. Adapun jenis data yang diperlukan adalah data primer dan data sekunder baik yang bersifat kualilalif maupun kuantitatif.

Hasil dari penelitian menunjukkan bahwa, pengalihan fungsi lahan sawah di Kecamatan Jaten semakin meningkat, hal ini dipengaruhi oleh letak geografis yang strategis, Pertumbuhan Penduduk dan Kebutuhan Perumahan, perkembangan industri, dan faktor individu Petani. Penyusutan lahan sawah secara nyata berpengaruh terhadap berkurangnya produksi padi secara total. Hal ini dibuktikan dengan hasil uji statistik yang menunjukkan penurunan produksi padi sampai dengan tahun 2018 sebesar 6.309,8 ton atau sekitar -2,9 persen/tahun. Berdasarkan tingkat
\end{abstract}


konsumsi beras penduduk sesuai dengan Susenas tahun 2013, maka diperkirakan pada tahun 2020 Kecamatan Jaten akan mengalami kekurangan produksi beras.

\section{Kata Kunci: Pengalihan Fungsi Lahan Sawah, Produksi Padi, Ketahanan Pangan Wilayah}

\section{PENGANTAR}

Indonesia merupakan negara agraris yang mempunyai lahan pertanian luas dan subur serta terletak di garis katulistiwa. Kondisi penduduk Indonesia beraneka ragam dan sebagian besar matapencaharianya sebagai petani. Perkembangan perekonomian global yang dinamis sangat berpengaruh terhadap sektor pertanian, sehingga sungguh ironis dengan kondisi Indonesia sebagai negara agraris namun harus mengimpor beberapa bahan makanan pokok dari luar negeri.

Seiring dengan transformasi desa ke perkotaan sebagai dampak pembangunan, maka kebutuhan akan lahan semakin meningkat, demikian pula yang terjadi di Kecamatan Jaten. Kecamatan Jaten mempunyai tanah sawah yang produktif dan seluruh areal persawahan yang ada beririgasi teknis. Selain itu, Kecamatan Jaten merupakan daerah strategis yang terletak di perbatasan Kota Surakarta dan Kabupaten Karanganyar. Kecamatan Jaten dapat disebut sebagai daerah pinggiran kota (urban fringe). Kondisi ini mendorong laju pengalihan fungsi lahan sawah ke sektor non pertanian. Mengingat semakin meningkatnya pengalihan fungsi lahan sawah produktif di Kecamatan Jaten dari tahun ke tahun, maka perlu adanya penelitian mengenai dampak pengalihan fungsi lahan sawah terhadap produksi padi dalam rangka ketahanan pangan wilayah.

Penelitian ini dilakukan di Kecamatan Jaten Kabupaten Karanganyar, yang memiliki luas wilayah 2.554,81 Ha, yang terdiri luas tanah kering 1.415,25 Ha, tanah sawah 1.139,56 Ha. Kecamatan Jaten dipilih karena merupakan pusat industri terbesar di Kabupaten Karanganyar dan merupakan wilayah kecamatan yang terjadi pengalihan fungsi lahan sawah terluas.

Penelitian ini bersifat deskriptif dengan pendekatan kuantitatif dan kualitatif. Adapun jenis data yang diperlukan adalah data primer dan data sekunder baik yang bersifat kualilalif maupun kuantitatif. Pengumpulan data tersebut diperoleh melalui tehnik observasi, wawancara mendalam (in depth interview), studi pustaka, dokumentasi (Sugiyono, 2013).

Data dan Informasi yang telah dikumpulkan dianalisis secara deskriptif kualitatif dan kuantitatif untuk menjawab permasalahan penelitian. Teknik analisis yang digunakan dalam menganalisis data disesuaikan dengan masalah yang diteliti yaitu: (1) Untuk mengetahui perkembangan pengalihan fungsi lahan sawah ke non sawah, jumlah produksi padi yang di hasilkan dari tahun ke tahun oleh sawah, ketahanan pangan wilayah Kecamatan Jaten menggunakan metode tabel atau grafik. (2) Untuk meramalkan jumlah penduduk, bagaimana pengalihan fungsi lahan sawah, produksi padi dan ketahanan pangan wilayah di Kecamatan Jaten pada tahun 2018 dengan metode rumusan pertumbuhan geometri : Pt $=$ Po $(1+r){ }^{n}$ (Subarsono.AG, 2013:39). (3) Untuk dapat mengetahui faktor-faktor pendorong pengalihan fungsi lahan sawah dengan tehnik wawancara dari beberapa sumber yang terkait. 
Catur Setyo Wibowo -- Dampak Pengalihan Fungsi Lahan Sawah Pada Produksi Padi Sampai Tahun 2018 Dan Implikasinya Terhadap Ketahanan Pangan Wilayah (Studi Di Kecamatan Jaten Kabupaten Karanganyar Propinsi Jawa Tengah)

\section{PEMBAHASAN}

\section{Teori Konversi Lahan}

Konversi lahan sawah akan berkaitan erat dengan teori sewa dan lokasi tanah. David Ricardo dalam teori mengenai sewa tanah berpendapat bahwa penduduk akan tumbuh sedemikian rupa sehingga tanah-tanah yang tidak subur akan digunakan dalam proses produksi, dimana sudah tidak bermanfaat lagi bagi pemenuhan kebutuhan manusia yang berada pada batas minimum kehidupan. (Reksohadiprojo-Karseno, 1985:25).

\section{Teori Kependudukan}

Menurut Malthus (1798) dalam sebuah essay tentang prinsip mengenai kependudukan yang berjudul principles of population, membuat ramalan bahwa jumlah populasi akan mengalahkan pasokan makanan, yang menyebabkan berkurangnya jumlah makanan perorang (Case and Fair, 1999:790). Malthus salah satu orang yang pesimis terhadap masa depan manusia. Hal itu didasari dari kenyataan bahwa lahan pertanian sebagai salah satu faktor produksi utama jumlahnya tetap. Kendati pemakaiannya untuk produksi pertanian bisa ditingkatkan, peningkatannya tidak akan seberapa. di lain pihak justru lahan pertanian akan semakin berkurang keberadaanya karena digunakan untuk membangun perumahan, pabrik-pabrik serta infrastruktur yang lainnya.

\section{Teori Produksi Pertanian}

Pada penyelenggaraan usaha tani, siapapun selalu berusaha agar hasil panennya meningkat. Ilmu ekonomi secara tidak langsung petani membandingkan antara hasil yang diharapkan akan diterima pada waktu panen dengan seluruh biaya yang dikeluarkan untuk pengolahan sawah. Hasil yang diperoleh Petani pada saat panen tersebut disebut "produksi”, sedangkan biaya yang dikeluarkan disebut "biaya produksi” (Rahim dan Hastuti, 2008:30).

\section{Teori Kebutuhan Pangan Wilayah}

Acuan kualitatif untuk ketersediaan pangan adalah Angka Kecukupan Gizi (AKG) rekomendasi Widyakarya Nasional Pangan dan Gizi XV Tahun 2012, yaitu energi sebesar $2150 \mathrm{kkal} / \mathrm{kapita} / \mathrm{hari}$ dan protein 57 gram/ kapita/hari. Kebutuhan beras sesuai AKG tersebut setara dengan $0,6 \mathrm{~kg} / \mathrm{kapita} / \mathrm{hari}$ atau 219 Kg/kapita /tahun. Menurut Suhardjo (2009:66) menyatakan bahwa dalam 100 gram beras terdapat kandungan kalori sebesar $352 \mathrm{Kkal}$, sehingga untuk mendapatkan $2150 \mathrm{Kkal}$ energi setara dengan 0,6 kg beras. Konsumsi perkapita berdasarkan Susenas (Sensus Sosial Ekonomi Nasional) tahun 2013, tingkat konsumsi beras nasional sebesar 97,4 kg/kapita/tahun. Proyeksi konsumsi beras tingkat nasional berdasarkan RPJMN bidang tanaman pangan dan pertanian tahun 20152019 ditetapkan sebesar 124,89 kg/kapita/ tahun (Depkes RI, 2013:109).

\section{Teori Ketahanan Pangan Wilayah}

Konsep ketahanan pangan dapat diterapkan untuk menyatakan situasi pangan pada berbagai tingkatan yaitu tingkat global, nasional, regional, dan tingkat rumah tangga serta individu yang merupakan suatu rangkaian sistem hirarkis. Konsep ketahanan pangan tersebut intinya bertujuan untuk mewujudkan terjaminnya ketersediaan pangan bagi umat manusia. Terdapat tiga aspek yang menjadi indikator ketahanan pangan suatu wilayah, yaitu sektor ketersediaan pangan, stabilitas 
ekonomi (harga) pangan, dan akses fisik maupun ekonomi bagi setiap individu untuk mendapatkan pangan.

\section{Deskripsi Wilayah Kecamatan Jaten Kondisi Geografi}

Kecamatan Jaten memiliki luas wilayah 2.554,81 Ha dengan ketinggian rata-rata 108 meter di atas permukaan laut, yang terdiri luas tanah kering 1.415,25 Ha, tanah sawah 1.139,56 Ha. Sedangkan luas untuk bangunan/ pekarangan $1239.64 \mathrm{Ha}$, tegalan/ladang seluas 11,95 Ha, dan tanah lain-lain 163,66 Нa. Kecamatan Jaten terbagi atas 8 desa, yaitu: Suruh kalang, Jati, Jaten, Dagen, Ngringo, Jetis, Sroyo, dan Brujul.

\section{Kondisi Kependudukan}

Berdasarkan data registrasi BPS tahun 2014, jumlah penduduk seluruh wilayah kecamatan Jaten sebanyak 81.480 jiwa, yang terdiri dari 40.062 jiwa penduduk laki-laki dan 41.418 jiwa penduduk perempuan. Desa dengan penduduk terbanyak adalah Desa Ngringo yaitu 26.521 jiwa (33 \%), kemudian Desa Jaten yaitu 15.305 jiwa (18,9 \%) dan Desa Sroyo sebanyak 9.764 jiwa (12,1 \%). Desa dengan penduduk paling sedikit di Kecamatan Jaten adalah Desa Suruh Kalang dengan penduduk 5,508 jiwa (6,3 \%) (BPS, 2014).

\section{Kondisi Sosial}

Kondisi sosial masyarakat di wilayah Kecamatan Jaten dapat dibedakan dari beberapa segi sumber penghidupannya. Kecamatan Jaten sebagai pusat industri berimplikasi pada matapencaharian penduduknya mayoritas sebagai buruh industri. Selain buruh industri juga terdapat petani, pedagang, wiraswasta, pengusaha sektor angkutan, PNS dan TNI Polri serta profesi lainnya. Kondisi sosial masyarakat Kecamatan Jaten terutama di daerah perbatasan Kota Surakarta (Desa Nringo, Jaten, Dagen, Sroyo dan Jetis) banyak dipengaruhi oleh kegiatan sektor industri. Hal tersebut berimplikasi pada kemunduran sektor pertanian dimana sebagian petani di wilayah perbatasan ini justru berharap agar lahan sawahnya laku terjual dengan harga yang tinggi untuk dijadikan perumahan maupun industri.

\section{Kondisi Pengalihan Lahan Sawah Fakta Pengalihan Fungsi Lahan Sawah di Kecamatan Jaten Kabupaten Karanganyar}

Perkembangan alih fungsi lahan sawah di Kecamatan Jaten dari tahun 2009-2013 tergolong cukup tinggi. Pada tahun 20092010 jumlah alih fungsi lahan hanya seluas 2,27 hektar, kemudian pada tahun 20102011 mengalami peningkatan yang cukup besar yaitu sebesar 63,2 hektar. Pada tahun 2011-2012 pengalihan fungsi lahan sawah di Kecamatan Jaten menurun menjadi 26,02 hektar, sedangkan pada kurun waktu tahun 2012-2013 pengalihan fungsi lahan sawah kembali naik menjadi 46,54 hektar. Walaupun dalam rentang waktu 2009 sampai 2010 jumlah alih fungsi lahan sangat kecil, namun pada tahun 2011 sampai dengan 2013 mengalami kenaikan yang sangat tinggi. Pengalihan fungsi lahan sawah di Kecamatan Jaten sudah tergolong tinggi. Setidaknya dalam kurun waktu 5 tahun tersebut terjadi pengalihan lahan sawah ke sektor non pertanian seluas 138,03 hektar (BPS, 2009-2013).

Hal tersebut terkait dengan pemberian izin dari beberapa kantor, yaitu: 
Catur Setyo Wibowo -- Dampak Pengalihan Fungsi Lahan Sawah Pada Produksi Padi Sampai Tahun 2018 Dan Implikasinya Terhadap Ketahanan Pangan Wilayah

(Studi Di Kecamatan Jaten Kabupaten Karanganyar Propinsi Jawa Tengah)

Pertama, Pemberian Izin Pengeringan Lahan Sawah oleh Kantor Badan Pertahanan Nasional. Sesuai data Badan Pertahanan Nasional pengeringan lahan sawah di Kecamatan Jaten pada kurun waktu 2009 sampai 2013 mencapai $717.402 \mathrm{~m}^{2}$ atau sekitar 71,74 Ha. Apabila dirata-rata dalam satu tahun setidaknya terjadi izin pengeringan lahan sawah di Kecamatan Jaten seluas $\pm 14,34$ Ha. Desa yang memiliki pengeringan lahan paling luas selama kurun waktu 2009-2013 adalah desa Jaten yaitu seluas $190.316 \mathrm{~m}^{2}(19,31 \mathrm{Ha})$, Desa Sroyo seluas136.950 m²(13,69 Ha), Desa Nringo seluas 127.335 m² (12,73 Ha) (BPS, 2009-2015).

Kedua, Pemberian Izin Lokasi Perumahan dan Industri oleh Kantor BPPT (Badan Pengkajian dan Penerapan Teknologi). Data izin lokasi prumahan dan industri yang dikeluarkan oleh BPPT (Badan Pengkajian dan Penerapan Teknologi) Kabupaten Karanganyar dalam kurun waktu 20092013 tersebut telah terjadi pemberian izin lokasi pembangunan perumahan dan industri seluas 485880 m2 (48,58 hektar), yang terdiri dari sektor perumahan $187.166 \mathrm{~m} 2$ (18,71 hektar) dan sektor industri 298.714 m2 (29.87 hektar). Apabila dilihat dari luas areal yang diberikan izin lokasi oleh BPPT Kabupaten Karanganyar, maka 60,5\% izin lokasi diberikan di sektor industri, sedangkan $38,5 \%$ di sektor perumahan.

\section{Peran Pemerintah Daerah Dalam Mengendalikan Pengalihan Fungsi Lahan Sawah.}

Dalam proses pengalihan fungsi lahan sawah ke non sawah, yang menjadi leading sector adalah BPN (Badan Pertanahan Nasional). Terlihat bahwa terjadi kurang sinergi dalam upaya menekan pengalihan fungsi lahan sawah antara Kantor Dinas pertanian, Pemerintah Kecamatan, BP4K, dan desa selaku pemangku jabatan paling bawah. Ketidak seriusan Pemerintah Daeraah dalam mempertahankan lahan sawah terlihat dalam RTRW Kabupaten Karanganyar dan dijelaskan dalam RDTR (Rencana Detail Tata Ruang) Kecamatan Jaten yang hanya memasukkan program LP2B Kecamatan Jaten seluas 660,35 dari luas tanah sawah yang tersisa saat ini 1139,65 hektar.

\section{Gambaran Pengalihan Fungsi Lahan Sawah Di Kecamatan Jaten Sampai Dengan Tahun 2018.}

Dengan melihat gambaran alih fungsi lahan sawah di Kecamatan Jaten dari tahun 2009-2013, maka dapat diprediksikan bagaimana gambaran alih fungsi lahan sawah pada tahun 2018 dengan menggunakan rumus pertumbuhan geometrik sebagai berikut: $\mathbf{P t}=$ $\mathbf{P o}(\mathbf{1}+\mathbf{r})^{\mathbf{n}}$. Pt = Prediksi keadaan yang akan datang, $\mathrm{Po}=$ Data tahun awal, $\mathrm{r}=$ Angka pertumbuhan, $\mathrm{n}=$ Range tahun

Berdasarkan data lahan sawah di Kecamatan Jaten mulai tahun 2009-2013, maka didapat angka (r) sebesar -0.0230574 atau 2,30\%. Dengan menggunakan rumus geometri maka diperkirakan luas lahan sawah di Kecamatan Jaten sesuai dengan tabel 1.

Tabel 1

Perkiraan Luas Lahan Sawah di Kecamatan Jaten 2014-2018

\begin{tabular}{ccc}
\hline Tahun & $\begin{array}{c}\text { Perkiraan Luas } \\
\text { Lahan (Ha) }\end{array}$ & $\begin{array}{c}\text { Penyusutan Lahan } \\
\text { (Ha) }\end{array}$ \\
\hline 2014 & 1113.28 & 26.28 \\
2015 & 1086.40 & 26.88 \\
2016 & 1058.90 & 27.5 \\
2017 & 1030.76 & 28.14 \\
2018 & 1001.98 & 28.78 \\
\hline
\end{tabular}

Sumber: Badan Pelaksana Penyuluh Pertanian dan Perikanan Kecamatan diolah 
Faktor Yang Berpengaruh Terhadap

Pengalihan Fungsi Lahan Sawah

Di Kecamatan Jaten, Kabupaten

Karanganyar

\section{Faktor Letak Geografis Kecamatan Jaten yang Strategis}

Kecamatan Jaten mempunyai letak yang sangat srategis dimana berbatasan langsung dengan Kota Surakarta dan Kabupaten Sukoharjo. Di dalam RTRW Kabupaten Karanganyar, Kecamatan Jaten ditetapkan sebagai kawasan strategis perkotaan yang berpotensi perekonomian tinggi. Kawasan ini disebut SUBOSUKOWONOSRATEN (Surakarta, Boyolali, Sukoharjo, Karanganyar, Wonogiri, Sragen dan Klaten). Penetapan Kecamatan Jaten sebagai pusat industri ini berakibat melambungnya harga tanah sehingga banyak petani yang tergiur untuk menjual sawahnya kepada investor.

\section{Faktor Pertumbuhan Penduduk dan Kebutuhan Perumahan}

Pada tahun 2009 jumlah penduduk Kecamatan Jaten sebanyak 70.993 jiwa, terdiri dari 35.219 laki-laki dan 35.744 perempuan. Kemudian pada tahun 2010 penduduk Kecamatan Jaten mengalami peningkatan sebanyak 116 orang menjadi 71.109 jiwa. Pada tahun 2011 BPS melakukan pemutahiran data sehingga Jumlah penduduk Kecamatan Jaten menjadi 80.726 jiwa yang terdiri dari 39.936 laki-laki dan 40.790 perempuan. Data BPS Pada tahun 2012 penduduk Kecamatan Jaten tercatat sebanyak 80.766 jiwa Sedangkan pada tahun 2013 jumlah penduduk Kecamatan Jaten meningkat menjadi 80.901 jiwa terdiri dari 39.807 laki-laki dan 41.094 perempuan. Pertumbuhan jumlah penduduk di Kecamatan Jaten mendorong peningkatan kebutuhan perumahan. Data dari kantor Kecamatan Jaten menyebutkan bahwa telah terjadi peningkatan jumlah komplek perumahan setiap tahunnya. Pada tahun 2009 jumlah komplek perumahan di Kecamatan Jaten adalah 10 komplek, sedangkan pada tahun 2013 berkembang menjadi 37 komplek perumahan (BPS, 2009-20013).

\section{Faktor Perkembangan Industri}

Laju perkembangan Industri besar, sedang dan kecil di Kecamatan Jaten dapat dilihat pada tabel 2.

Tabel 2

Perkembangan Industri Besar, Sedang dan Kecil di Kecamatan Jaten 2009-2014

\begin{tabular}{cccc}
\hline \multirow{2}{*}{ Tahun } & \multicolumn{3}{c}{ Jenis Industri } \\
\cline { 2 - 4 } & Besar & Sedang & Kecil \\
\hline 2009 & 56 & 19 & 1.835 \\
2010 & 59 & 20 & 1.847 \\
2011 & 65 & 22 & 1.855 \\
2012 & 68 & 24 & 1.863 \\
2013 & 70 & 25 & 1.872 \\
2014 & 79 & 30 & 1.895 \\
\hline
\end{tabular}

Sumber: Kantor Kecamatan Jaten.

Tabel 2 di atas dapat dilihat bahwa jumlah industri di Kecamatan Jaten setiap tahunnya bertambah. Laju perkembangan industri besar rata-rata sekitar $4,8 \%$ per tahun, sedangkan industri sedang 4,9\% per tahun. Perkembangan industri besar dan sedang yang terjadi di Kecamatan Jaten tentunya akan mendorong terjadinya pengalihan fungsi lahan sawah ke sektor industri.

\section{Faktor Kurangnya Peran Pemerintah Daerah}

Kurangnya peran pemerintah daerah dari tingkat kabupaten sampai dengan desa dalam mengendalikan pengalihan fungsi 
Catur Setyo Wibowo -- Dampak Pengalihan Fungsi Lahan Sawah Pada Produksi Padi Sampai Tahun 2018 Dan Implikasinya Terhadap Ketahanan Pangan Wilayah

(Studi Di Kecamatan Jaten Kabupaten Karanganyar Propinsi Jawa Tengah)

lahan sawah dapat dilihat dari beberapa indikator yaitu: (1) Indikator yuridis berupa lemahnya penegakkan peraturan perundangundangan yang mengikat (Undang-Undang, Perda) dengan ketentuan sanksi yang tegas. (2) Tidak adanya pemberian insentif bagi pemilik lahan sawah yang mempertahankan lahannya. (3) Minimnya alokasi dana APBD bidang pertanian untuk mendorong pemerintah daerah dalam mengendalikan konversi lahan pertanian terutama sawah. (4) Fragmentasi lahan pertanian untuk pembangunan daerah dalam pembuatan Rencana Tata Ruang Wilayah (RTRW), RDTR (Rencana Detail Tata Ruang).

\section{Faktor Individu Petani}

Proses pembangunan (development) sebagai upaya modenisasi desa telah mengubah culture masyarakat agraris menjadi masyarakat industri. Hal inilah yang mendorong banyak terjadi perubahan fungsi lahan sawah menjadi industri maupun perumahan. Faktor intern petani sangat berpengaruh terhadap laju pengalihan fungsi lahan sawah di Kecamatan Jaten. Hasil wawancara yang dilakukan Peneliti dengan beberapa petani di wilayah Kecamatan Jaten menunjukkan bahwa para petani selaku pemilik sawah mempunyai peran yang penting dalam pengalihan fungsi lahan sawah.

\section{Dampak Pengalihan Fungsi Lahan Sawah Terhadap Ketahanan Pangan Wilayah}

\section{Produksi Padi dan Kebutuhan Saat ini}

Jumlah produksi padi sawah di Kecamatan Jaten pada tahun 2009-2010 menunjukkan penurunan dari 23.134 ton menjadi 20.916 ton atau 9,6\%. Pada tahun
2010-2011 produksi padi di Kecamatan Jaten terjadi penurunan yang sangat significant dari 20.916 ton menjadi 14.636 ton atau 30\%. Kemudian pada tahun 2011-2012 produksi padi mengalami kenaikan sebesar $15,2 \%$ menjadi 16.874 ton. Pada tahun 2012-2013 produksi padi di Kecamatan Jaten kembali mengalami kenaikan 18,3\% menjadi 19.968 ton. Mengacu pada tingkat produksi beras dan pertumbuhan penduduk di Kecamatan Jaten tahun 2009-2013, maka diperoleh gambaran perbandingan sebagaimana pada tabel 3 .

Tabel 3

Perbandingan Perkembangan Produksi Beras dan Penduduk Kecamatan Jaten 2010-2013

\begin{tabular}{ccc}
\hline \multirow{2}{*}{ Tahun } & Produksi Beras & Penduduk \\
\cline { 2 - 3 } & Pertumbuhan (\%) & Pertumbuhan (\%) \\
\hline 2010 & -11 & 1,17 \\
2011 & -18 & 7,2 \\
2012 & -16 & 0,04 \\
2013 & 10 & 0,88 \\
\hline
\end{tabular}

Sumber: Badan Pelaksana Penyuluh Pertanian dan Peternakan Kecamatan Jaten, BPS Kabupaten Karanganyar

Menurut Dinas Kesehatan (2013), kisaran angka kecukupan gizi (AKG) rata-rata asupan energi manusia Indonesia perkapita/ hari adalah $2.150 \mathrm{kkal} / \mathrm{hari}$ atau setara dengan 0,6 kg beras/hari, atau $219 \mathrm{Kg}$ beras/tahun.

Tabel 4

Kebutuhan Beras Penduduk Kecamatan Jaten 20092013

\begin{tabular}{ccc}
\hline \multirow{2}{*}{ Tahun } & \multicolumn{2}{c}{ Jumlah Kebutuhan Beras } \\
\cline { 2 - 3 } & Sesuai AKG & Sesuai Susenas \\
\hline 2009 & 16.298 & 6.795 \\
2010 & 16.490 & 6.788 \\
2011 & 17.678 & 7.223 \\
2012 & 17.687 & 7.056 \\
2013 & 17.844 & 6.968 \\
\hline
\end{tabular}

Sumber: BPS Kabupaten Karanganyar, Dinas Kesehatan, Dinas Pertanian Kabupaten Karanganyar diolah 
Berdasarkan prediksi Susenas tahun 2014, tingkat konsumsi beras nasional sebesar 97,3 kg/kapita/tahun, maka dapat dihitung kebutuhan beras di Kecamatan Jaten dapat dilihat pada tabel 4 .

\section{Gambaran Kebutuhan Pangan dan Ketahanan Pangan Kecamatan Jaten Sampai Tahun 2018}

Dengan menggunakan rumus pertumbuhan geometri, maka diperoleh rata-

\section{Tabel 5}

Perkiraan Luas Panen, Produksi Padi dan Produktivitas Lahan Sawah di Kecamatan Jaten 2014-2018

\begin{tabular}{cccc}
\hline Tahun & $\begin{array}{c}\text { Perkiraan } \\
\text { Luas Panen } \\
\text { (Ha) }\end{array}$ & $\begin{array}{c}\text { Perkiraan } \\
\text { Produksi Padi } \\
\text { (Ton) }\end{array}$ & $\begin{array}{c}\text { Asumsi } \\
\text { Produktivitas } \\
\text { (Ton/Ha) }\end{array}$ \\
\hline 2014 & $3.181,6$ & $19.375,5$ & 6,09 \\
2015 & $3.028,9$ & $18.765,3$ & 6,20 \\
2016 & $2.883,5$ & $18.137,1$ & 6,29 \\
2017 & $2.745,0$ & $17.490,2$ & 6,37 \\
2018 & $2.613,2$ & $16.824,2$ & 6,44 \\
\hline
\end{tabular}

Sumber: BP4K Jaten, BPS, Kantor Ketahanan Pangan Kabupaten Karanganyar diolah rata (r) luas panen padi dari tahun 2009-2013 sebesar - 0.048313 atau $-4,81 \%$. Perkiraan luas panen, produksi dan produktivitas padi pada tahun 2009 sampai tahun 2018 dapat dilihat pada tabel 5 .

Sesuai dengan angka Konversi padi ke beras berdasarkan Kantor Ketahanan Pangan Kabupaten Karanganyar, maka dapat diperkirakan produksi beras dapat dilihat pada tabel 6.

Sesuai dengan angka perkiraan jumlah penduduk pada tahun 2014 sampai dengan 2018, maka perkiraan produksi beras dapat dilihat pada tabel 7 .

Mengacu pada perkiraan konsumsi beras/kapita/tahun sesuai Susenas, maka produksi beras di Kecamatan Jaten pada tahun 2018 diperkirakan sudah berada pada ambang batas minimal. Diperkirakan pada tahun 2020 produksi beras sudah mengalami kekurangan sebesar -69,7 ton, dengan asumsi rata-rata konsumsi beras 102,7 kg/kapita/tahun

Tabel 6

Perkiraan Produksi Beras di Kecamatan Jaten Tahun 2014-2018

\begin{tabular}{ccccc}
\hline Tahun & $\begin{array}{c}\text { Produksi Padi } \\
\text { GKG }\end{array}$ & $\begin{array}{c}\text { Penyusutan } \\
\mathbf{7 . 3 0 \%}\end{array}$ & $\begin{array}{c}\text { Produksi Padi } \\
\text { Netto }\end{array}$ & $\begin{array}{c}\text { Hasil Produksi Beras } \\
\text { Setelah Konversi 62.74\% }\end{array}$ \\
\hline 2014 & $19.375,46$ & $1.414,41$ & $17.961,05$ & $11.268,76$ \\
2015 & $18.765,33$ & $1.369,87$ & $17.395,46$ & $10.913,91$ \\
2016 & $18.137,10$ & $1.324,01$ & $16.813,09$ & $10.548,53$ \\
2017 & $17.490,23$ & $1.276,79$ & $16.213,44$ & $10.172,31$ \\
2018 & $16.824,16$ & $1.228,16$ & $15.595,99$ & $9.784,93$ \\
\hline
\end{tabular}

Sumber: UPT. BP4K Jaten, BPS, Kantor Ketahanan Pangan Kab. Karanganyar diolah

Tabel 7.

Perbandingan Kebutuhan Beras (ton/tahun) dan produksi beras (ton) di Kecamatan Jaten 2014-2018

\begin{tabular}{cccccc}
\hline \multirow{2}{*}{ Tahun } & \multirow{2}{*}{$\begin{array}{c}\text { Produksi Beras } \\
\text { (Ton) }\end{array}$} & \multicolumn{2}{c}{ Kebutuhan Beras } & \multicolumn{2}{c}{ Keterangan } \\
\cline { 3 - 5 } & & Sesuai AKG & Sesuai Susenas & Sesuai AKG & Sesuai Susenas \\
\cline { 3 - 6 } & 11.269 & 17.844 & 7.931 & -6.575 & 3.338 \\
2014 & 10.914 & 18.075 & 8.479 & -7.161 & 2.435 \\
2015 & 10.549 & 18.310 & 8.589 & -7.761 & 1.960 \\
2017 & 10.172 & 18.547 & 8.700 & -8.375 & 1.472 \\
2018 & 9.785 & 18.788 & 8.813 & -9.003 & 972 \\
\hline
\end{tabular}

Sumber : UPT.BP4K Jaten, BPS Kab.Karanganyar dan Kantor Ketahanan Pangan Kab. Karanganyar diolah 
Catur Setyo Wibowo -- Dampak Pengalihan Fungsi Lahan Sawah Pada Produksi Padi Sampai Tahun 2018 Dan Implikasinya Terhadap Ketahanan Pangan Wilayah

(Studi Di Kecamatan Jaten Kabupaten Karanganyar Propinsi Jawa Tengah)

Estimasi Produksi dan Konsumsi Beras Dalam Rangka Mencapai Kemandirian Pangan

Estimasi produksi dan konsumsi beras di Kecamatan Jaten dalam rangka pencapaian kemandirian pangan dan ketahanan pangan dapat dilihat pada tabel 8 .

Perbandingan antara perkiraan produksi padi di Kecamatan Jaten tahun 2014-2018 dan estimasi produksi padi berdasarkan konsumsi beras sesuai AKG serta RPJMN bidang pangan dan pertanian dapat dilihat pada gambar 1 .
Pada gambar 1 dapat dijelaskan bahwa garis merah merupakan prediksi produksi padi tahun 2014 sampai tahun 2018. Garis biru merupakan estimasi produksi padi berdasarkan RPJMN dengan mengacu pada perkiraan jumlah penduduk dan konsumsi rata-rata beras/kapita/ tahun. Garis hijau adalah estimasi produksi padi berdasarkan konsumsi AKG. Zona kemandirian pangan berada di antara garis biru dan garis hijau. Prediksi produksi padi di Kecamatan Jaten mula-mula masih berada pada zona kemandirian pangan, namun seiring dengan berkurangnya lahan sawah maka produksi padi cenderung

Tabel 8

Estimasi Konsumsi Beras, Produksi Padi, Perkiraan Luas Panen dan Produktivitas Lahan Kecamatan Jaten 2014-2018

\begin{tabular}{cccccc}
\hline Tahun & $\begin{array}{c}\text { Konsumsi } \\
\text { Beras }\end{array}$ & $\begin{array}{c}\text { Cadangan Pangan } \\
\text { Wilayah } \\
\text { (Ton GKG) }\end{array}$ & $\begin{array}{c}\text { Estimasi } \\
\text { Produksi Padi } \\
\text { (Ton GKG) }\end{array}$ & $\begin{array}{c}\text { Perkiraan } \\
\text { Luas Panen Padi } \\
\text { (Ha) }\end{array}$ & $\begin{array}{c}\text { Perkiraan } \\
\text { Produktivitas Lahan } \\
\text { (Ton KG/Ha) }\end{array}$ \\
\hline 2014 & 10.176 & 468,9 & 17.872 & $3.181,6$ & 5,6 \\
2015 & 10.308 & 468,9 & 18.098 & $3.028,9$ & 6,0 \\
2016 & 10.441 & 468,9 & 18.327 & $2.883,5$ & 6,4 \\
2017 & 10.577 & 468,9 & 18.558 & $2.745,0$ & 6,8 \\
2018 & 10.714 & 468,9 & 18.793 & $2.613,2$ & 7,2 \\
\hline
\end{tabular}

Sumber : UPT. BP4K Jaten, BPS, RPJMN, dan Kantor Ketahanan Pangan Kabupaten Karanganyar diolah

Gambar 1. Perbandingan Antara Perkiraan Produksi Padi di Kecamatan Jaten Tahun 2014-2018 dan Estimasi Produksi Padi Berdasarkan Konsumsi Beras Sesuai AKG Serta RPJMN

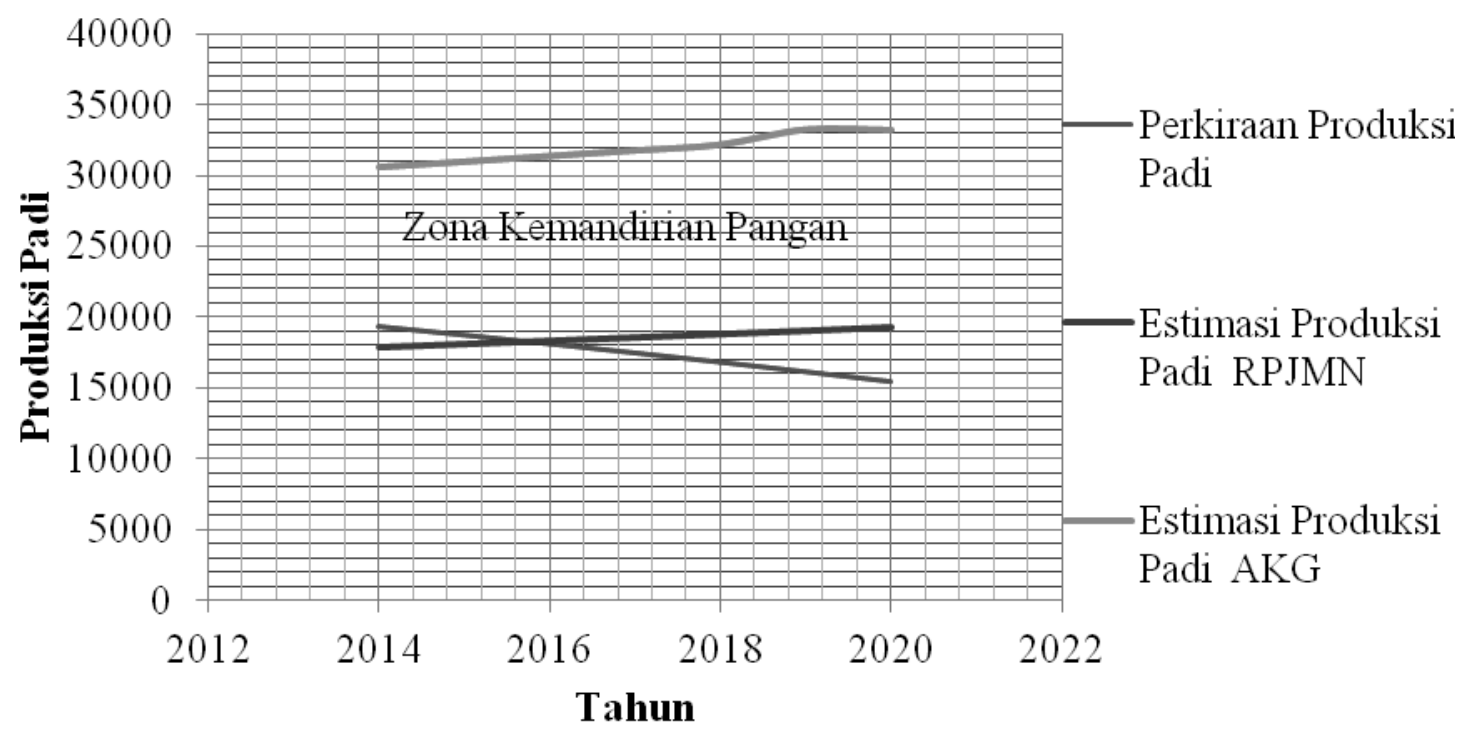

Sumber: BP4K Jaten, BPS, Kantor Ketahanan Pangan Karanganyar, RPJMN diolah. 
menurun dan berada di bawah zona kemandirian pangan setelah tahun 2016. Pada tahun 2018 diperkirakan produksi padi turun ke angka 15.595 ton. Sedangkan estimasi poduksi padi yang harus dicapai berdasarkan RPJMN dan AKG cenderung semakin naik seiring dengan bertambahnya kebutuhan konsumsi beras akibat bertambahnya jumlah penduduk. Estimasi produksi padi yang harus dicapai berdasarkan RPJMN pada tahun 2018 berkisar 19.272 ton, sedangkan berdasarkan AKG adalah 33.250 ton.

\section{SIMPULAN}

Berdasarkan uraian di atas dapat ditarik simpulan sebagai berikut:

Pertama, pada kurun waktu 2009-2013 di Kecamatan Jaten Kabupaten Karanganyar telah terjadi pengalihan fungsi lahan sawah seluas 138,03 hektar dengan penyusutan ratarata sebesar $2,3 \%$ per tahun. Wilayah yang mengalami penyusutan lahan sawah paling luas yaitu Desa Jati dengan penyusutan sebesar 36 hektar dan rata rata penyusutan 4,6\% per tahun. Sedangkan wilayah yang mengalami penyusutan paling kecil yaitu Desa Ngringo dengan penyusutan 5 hektar atau sekitar 1,6\% per tahun.

Kedua, pengalihan fungsi lahan sawah yang terjadi di Kecamatan Jaten disebabkan oleh letak geografis yang sangat strategis, kepadatan penduduk dan kebutuhan perumahan yang semakin meningkat, perkembangan sektor industri yang semakin pesat, kurangnya peran pemerintah daerah dan faktor individu Petani pemilik lahan sawah.

Ketiga, penyusutan lahan sawah yang terjadi secara nyata berpengaruh terhadap berkurangnya produksi padi secara total, namun belum dapat dibuktikan berpengaruh langsung terhadap penurunan produktivitas lahan. Hal ini dibuktikan dengan hasil uji statistik yang menunjukkan penurunan produksi padi dari tahun 2009 sampai tahun 2018 sebesar 6.309,8 ton atau sekitar -2,9\% per tahun. Diperkirakan pada tahun 2020 Kecamatan Jaten akan mengalami kekurangan produksi beras. Untuk mengimbangi laju penurunan produksi padi akibat pengalihan fungsi lahan sawah di Kecamatan Jaten, maka produktivitas padi harus mampu ditingkatkan sebesar 1,3 ton GKG/Ha sampai tahun 2018 dengan perkiraan produktivitas sekitar 7,2 ton GKG/Ha.

Selanjutnya direkomendasikan hal-hal sebagai berikut:

Pertama, perlu adanya proses penegakkan hukum yang tegas berdasarkan pada UU RI No. 41 Tahun 2009 tentang Perlindungan Lahan Pertanian Pangan Berkelanjutan dan didukung dengan Perda Kabupaten Karanganyar Nomor 12 tahun 2012 tentang pengendalian perubahan penggunaan tanah pertanian ke non pertanian di Kabupaten Karanganyar secara konsisten. Hal ini dapat dilakukan dengan membentuk tim pengawas gabungan dari instansi terkait.

Kedua, untuk menekan pertumbuhan penduduk di Kecamatan Jaten perlu adanya upaya nyata pengendalian jumlah penduduk melalui optimalisasi program keluarga berencana, program penundaan usia perkawinan dan regulasi urbanisasi penduduk.

Ketiga, untuk mencapai kemandirian pangan di Kecamatan Jaten, perlu adanya upaya meningkatkan produktivitas lahan melalui program intensifikasi pertanian sehingga dapat meningkatkan produksi padi sampai 7,2 ton GKG/hekter.

Keempat, agar para petani di Kecamatan Jaten masih tetap mempertahankan lahannya untuk menanam padi, perlu diberikan insentif 
Catur Setyo Wibowo -- Dampak Pengalihan Fungsi Lahan Sawah Pada Produksi Padi Sampai Tahun 2018 Dan Implikasinya Terhadap Ketahanan Pangan Wilayah

(Studi Di Kecamatan Jaten Kabupaten Karanganyar Propinsi Jawa Tengah)

berupa: (1) Keringanan atau penghapusan pajak PBB sawah bagi petani yang menanam padi. (2) Pemberian pinjaman kredit lunak bagi petani padi dengan suku bunga maksimal 3 sampai 6\%, dengan grace period antara 1 sampai 3 tahun. (3) Penerapan perlindungan pertanian (agricultural protectionism) kususnya komoditas padi dengan menjaga stabilitas pasokan beras dan insentif harga. (4) Penyediaan bibit padi unggul padi secara gratis bagi petani di Kecamatan Jaten. (5) Pendampingan secara intensif oleh penyuluh lapangan. (6) Perbaikan sistem irigasi di Kecamatan Jaten. (7) Pengembangan lembaga dan jaringan bisnis mulai dari kelompok tani, koperasi, dan asosiasi, dari tingkat desa, kecamatan dan kabupaten.

Kelima, perlu adanya penambahan alokasi dana APBD bidang pertanian untuk pemberian insentif bagi petani penanam padi di Kecamatan Jaten, dalam rangka mendukung tercapainya ketahanan pangan wilayah.

\section{DAFTAR PUSTAKA}

BPS 2009, Kecamatan Jaten Dalam Angka 2009, Karanganyar : BPS.

BPS 2010, Kecamatan Jaten Dalam Angka 2010, Karanganyar : BPS.
BPS 2011, Kecamatan Jaten Dalam Angka 2011, Karanganyar : BPS.

BPS 2012, Kecamatan Jaten Dalam Angka 2012, Karanganyar : BPS.

BPS 2013, Kecamatan Jaten Dalam Angka 2013, Karanganyar : BPS.

BPS 2014, Kecamatan Jaten Dalam Angka 2014, Karanganyar: BPS.

Case and Fair, 1999, Mikro Ekonomi Intermediate (terjemahan), Jakarta : Gramedia.

Depkes RI, 2013, Komposisi Zat Gizi Makanan Indonesia, Jakarta, Departemen Kesehatan BPP Kesehatan PPP Gizi.

Rahim. A.dan. Hastuti. DRW.2008. Ekonomika Pertanian, Jakarta : Penebar Swadaya.

Reksohadiprojo dan Karseno, 1985, Ekonomi perkotaan, Yogyakarta : BPFE

Subarsono.AG, 2013, Analisis Kebijakan Publik Konsep, Teori dan Aplikasi, Yogyakarta:Pustaka Pelajar Cetakan V.

Suharjo, 2009, Pangan, Gizi dan Pertanian, Jakarta :Universitas Indonesia (UI Press)

Sugiyono, 2013, Metode Penelitian Kuantitatif, Kualitatif dan $R \& D$, Bandung: Alfabeta. 


\title{
PENERAPAN $e$-PROCUREMENT DALAM PROSES PENGADAAN BARANG DAN JASA PEMERINTAH GUNA MENDUKUNG KETAHANAN TATA PEMERINTAHAN DAERAH (Studi Pada Unit Layanan Pengadaan Barang Dan Jasa Pemerintah Kabupaten Penajam Paser Utara Provinsi Kalimantan Timur)
}

\author{
Rahmat Hidayat \\ Pemerintah Kabupaten Penajam Paser Utara, Kaltim \\ e-mail: praja.rahmat@gmail.com
}

\begin{abstract}
The purpose of this study was to analyzed the application of the principle of e-Procurement in Procurement Services Unit in the Government District Penajam Paser Utara, examines the obstacles faced by the Procurement Services Unit in the process procurement of goods and services by the government through e-procurement process and to formulated strategies that were done overcome by Procurement Services Unit to the obstacles in implementation of e-procurement to supported the resilience of governance in the district Penajam Paser Utara.

The research method used was descriptive method with quantitative and qualitative approaches. The data was collected through questionnaires, interviews, observation and documentation. The measurement applied Likert scale was applied to 32 Procurement Services Unit officers and informant interviews to 3 people who knew in depth about the implementation of e-procurement in Penajam Paser Utara.

The research showed the application of the principles of e-procurement in district Penajam Paser Utara district that generally was going according to applicable regulations, but there were still some obstacles in its application, namely Procurement Services Unit institution, infrastructures, and human resources. It require the government efforts to resolve these obstacles in order to supported the resilience of regional governance in Penajam Paser Utara district.
\end{abstract}

Keywords : e-Procurement, The Resilience of Local Governance

\begin{abstract}
ABSTRAK
Tujuan penelitian ini untuk menganalisis penerapan prinsip e-procurement pada Unit Layanan Pengadaan Barang dan Jasa di Pemerintah Kabupaten Penajam Paser Utara, mengkaji kendala yang dihadapi Unit Layanan Pengadaan dalam proses pengadaan barang dan jasa pemerintah melalui proses e-procurement serta untuk merumuskan strategi yang dilakukan Unit Layanan Pengadaan dalam mengatasi kendala penerapan e-procurement guna mendukung ketahanan tata pemerintahan daerah di Kabupaten Penajam Paser Utara.

Metode penelitian yang digunakan yaitu metode penelitian deskriptif dengan perpaduan kuantitatif dan kualitatif. Teknik pengumpulan data dilakukan dengan penyebaran kuesioner, wawancara,observasi dan studi pustaka. Pengukuran menggunakan skala Likert kepada 32 orang petugas ULP dan wawancara kepada 3 orang informan yang mengetahui secara mendalam tentang penerapan e-procurement di Kabupaten Penajam Paser Utara.

Hasil penelitian menunjukkan penerapan prinsip e-procurement di Kabupaten Penajam Paser Utara secara umum sudah berjalan sesuai peraturan yang berlaku namun masih terdapat beberapa kendala dalam penerapannya, yakni kelembagaan ULP, Infrastruktur, dan SDM. Untuk itu diperlukan strategi pemerintah daerah dalam mengatasi kendala tersebut guna mendukung ketahanan tata pemerintahan daerah di Kabupaten Penajam Paser Utara.
\end{abstract}

Kata Kunci : e-Procurement, Ketahanan Tata Pemerintahan Daerah 
Rahmat Hidayat -- Penerapan E-Procurement Dalam Proses Pengadaan Barang Dan Jasa Pemerintah Guna Mendukung Ketahanan Tata Pemerintahan Daerah (Studi Pada Unit Layanan Pengadaan Barang Dan Jasa Pemerintah Kabupaten Penajam Paser Utara Provinsi Kalimantan Timur)

\section{PENGANTAR}

Kabupaten Penajam Paser Utaramerupakan salah satu daerah pemekaran di Provinsi Kalimantan Timur, sesuai dengan diterbitkannya UU No.7 Tahun 2002 tanggal 10 April 2002 tentang Pembentukan Kabupaten Penajam Paser Utara. Setelah pemekaran, Kabupaten Penajam Paser Utara terus berbenah diri untuk dapat melaksanakan segala ketentuan sebagai daerah otonom yaitu dalam penyelenggaraan urusanurusan pemerintahan, khususnya yang menjadi kewenangan Pemerintah Kabupaten Penajam Paser Utara.

Berkembangnya kebutuhan masyarakat menuntut Pemerintah Kabupaten Penajam Paser Utara untuk dapat menciptakan programprogram inovasi yang mampu menjawab tuntutan masyarakat secara efektif. Oleh karena itu, tuntutan untuk melaksanakan reformasi administrasi semakin tinggi. Salah satu yang menjadi sorotan Pemerintah Kabupaten Penajam Paser Utara untuk memperbaiki pelayanan publik yakni dalam hal pengadaan barang dan jasa.

Pemerintah Kabupaten Penajam Paser Utara terus menyempurnakan kegiatan pelelangan secara elektronik atau e-procurement. Hal itu dilakukan agar kepercayaan publik kepada aparat pemerintah di PPU dalam menjalankan roda pemerintahan dan pembangunan di daerah dapat berjalan sesuai dengan yang diinginkan. Demikian dikatakan, Plt. Sekda PPU, H Tohar saat membacakan sambutan Bupati PPU, H. Yusran Aspar ketika digelar pelatihan pengadaan barang dan jasa (barjas) serta ujian sertifikasi barjas pemerintah (http://www.korankaltim.com/pemkab-ppusempurnakan-e-procurement/).

Gambaran umum pengadaan barang dan jasa pemerintah di Indonesia khususnya di
Kabupaten Penajam Paser Utara masih dirasa tidak efisien dan transparan, karena adanya beberapa permasalahan dalam pelaksanaan pengadaan barang dan jasa, yaitu:

Pertama, kapasitas manajemen dan kelembagaan yakni kurangnya kapasitas dan integritas sumber daya manusia untuk mengelola pengadaan barang dan jasa. Hal ini sesuai kutipan informasi yang berasal dari media massa elektronik yang berjudul "Oknum ULP PPU Diduga Atur Pemenang Lelang, Penajam -Seorang oknum petugas tim Unit Lelang Pengadaan (ULP) Setkab Penajam Paser Utara (PPU) kedapatan mengarahkan pengaturan lelang, kepada pengusaha yang akan menjadi peserta lelang salah satu proyek" (http://m. inilah.com/news/detail/1777007/oknum-ulpppu-diduga-atur-pemenang-lelang).

Kedua, adanya intervensi oleh penyelenggara negara dalam hal ini oknum anggota legislatif dalam pengadaan barang dan jasa di Kabupaten Penajam Paser Utara. Berdasarkan informasi media massa elektronik yang berjudul “DPRD Penajam Paser Utara Intervensi Layanan Pengadaan Secara Elektronik (LPSE)" (https://harianmahakam. wordpress.com/2014/10/25/dprd-penajampaser-utara-intervensi-layanan-pengadaansecara-elektronik-lpse/).

Ketiga, belum optimalnya proses pengadaan barang dan jasa di Kabupaten Penajam Paser Utara. Proses pengadaan masih berjalan lamban sehingga menghambat proses pembangunan di Penajam Paser Utara. Hal ini sesuai dengan kutipan berita media massa elektronik yang berjudul "Sejumlah Lelang Proyek Lamban”(http://www.korankaltim. com/sejumlah-lelang-proyek-lamban/).

Beberapa permasalahan menunjukan indikasi inefisiensi ataupun korupsi pada 
proses pengadaan barang dan jasa pemerintah. Oleh karena itu, layanan e-procurement yang memanfaatkan teknologi informasi dan komunikasi menjadi sebuah instrument pendekatan yang strategis untuk memecahkan permasalahan tersebut sehingga diharapkan secara cepat dapat memperbaiki kinerja pengadaan barang dan jasa pemerintah di Kabupaten Penajam Paser Utara.

Berdasarkan latar belakang masalah di atas, dikaji "Penerapan E-procurement Dalam Proses Pengadaan Barang Dan Jasa Pemerintah Guna Mendukung Ketahanan Tata Pemerintahan Daerah (Studi Pada Unit Layanan Pengadaan Barang Dan Jasa Pemerintah Kabupaten Penajam Paser Utara Provinsi Kalimantan Timur)".

Adapun tujuan dari penelitian ini yakni: (1) Untuk menganalisis penerapan prinsip e-procurement pada Unit Layanan Pengadaan Barang dan Jasa di Pemerintah Kabupaten Penajam Paser Utara Provinsi Kaltim sesuai dengan Perpres 54 Tahun 2010. (2) Untuk mengkaji kendala yang dihadapi Unit Layanan Pengadaan Pemerintah Kabupaten Penajam Paser Utara dalam proses pengadaan barang dan jasa pemerintah melalui proses e-procurement. (3) Untuk merumuskan strategi yang dilakukan Unit Layanan Pengadaan Pemerintah Kabupaten Penajam Paser Utara dalam mengatasi kendala penerapan e-procurement guna mendukung ketahanan tata pemerintahan daerah di Kabupaten Penajam Paser Utara.

Penelitian ini menggunakan bentuk penelitian deskriptif dengan menggunakan perpaduan kuantitatif dan kualitatif. Deskriptif kuantitatif yaitu mendeskripsikan hasil penelitian dalam bentuk persentase, sedangkan deskriptif kualitatif yaitu mendeskripsikan hasil penelitian dalam bentuk kata-kata atau kalimat. Seperti yang diungkapakan oleh Narbuko dan Achmadi (2005: 44) bahwa penelitian deskriptif yakni penelitian yang berusaha untuk menuturkan pemecahan masalah yang ada pada saat sekarang berdasarkan data-data.

Tahap pertama peneliti menggunakan metode kuantitatif. Setelah selesai tahap pertama, kemudian melakukan penelitian dengan menggunakan metode kualitatif. Dalam penelitian ini, metode yang dominan digunakan yaitu kuantitatif. Oleh karena itu, teknik penggalian data utama melalui penyebaran kuesioner. Sementara metode kualitatif yang dilakukan melalui teknik wawancara dan observasi dilakukan sebagai pelengkap untuk mendukung data penelitian.

Pemilihan lokasi atau site selection menurut Sukmadinata (2007:102) berkenaan dengan penentuan unit, bagian, kelompok, dan tempat dimana orang-orang terlibat di dalam kegiatan atau peristiwa yang diteliti. Lokasi dalam penelitian ini yaitu Unit Layanan Pengadaan (ULP) Pemerintah Kabupaten Penajam Paser Utara, Kaltim.

Alasan dipilihnya lokasi penelitian ini karena Kabupaten Penajam Paser Utara merupakan salah satu kabupaten pemekaran yang ada di Kalimantan Timur sehingga termasuk dalam kabupaten yang sedang melaksanakan proses pembangunan di segala bidang, salah satunya ditempuh melalui pengadaan barang dan jasa pemerintah. Oleh karena itu, e-procurement dalam pengadaan barang dan jasa pemerintah guna mendukung ketahanan tata pemerintahan di Kabupaten Penajam Paser Utara, Kaltim.

Jenis data dalam penelitian ini terbagi menjadi dua, yaitu data primer dan data sekunder, data primer diperoleh melalui tiga cara yaitu melalui observasi, penyebaran 
Rahmat Hidayat -- Penerapan E-Procurement Dalam Proses Pengadaan Barang Dan Jasa Pemerintah Guna Mendukung Ketahanan Tata Pemerintahan Daerah (Studi Pada Unit Layanan Pengadaan Barang Dan Jasa Pemerintah Kabupaten Penajam Paser Utara Provinsi Kalimantan Timur)

kuesioner, dan wawancara, sedangkan untuk data sekunder lebih banyak diperoleh melalui studi terhadap penelitian dan literatur yang telah diterbitkan.

Penelitian ini berfokus pada penyelenggara negara dalam menjalankan e-procurement dalam hal ini Unit Layanan Pengadaan Kabupaten Penajam Paser Utara. Adapun metode pengambilan sampel dalam penelitian ini dibagi menjadi dua, yakni sebagai berikut: (1) Penentuan Responden. Penentuan pengambilan sampel apabila kurang dari 100 lebih baik diambil semua hingga penelitiannya merupakan penelitian populasi (Arikunto, 2008:116). Adapun responden dalam penelitian ini yakni seluruh petugas ULP Kabupaten Penajam Paser Utara yang berjumlah 32 orang. (2) Penentuan Informan. Dalam menetapkan informan menggunakan teknik snowball sampling. Snowball sampling adalah teknik pengambilan sampel dengan bantuan key-informan, dan dari key informan inilah akan berkembang sesuai petunjuknya. Dalam hal ini peneliti hanya mengungkapkan kriteria sebagai persyaratan untuk dijadikan sampel. (Subagyo, 2006:31). Informan dalam penelitian ini yakni: Sekretaris Daerah Kabupaten Penajam Paser Utara, Sekretaris Umum dan Sekretaris Teknis ULP Kabupaten Penajam Paser Utara.

Variabel yang digunakan adalah: (1) Variabel Bebas (Independent Variable). Dalam penelitian ini yang menjadi variabel bebas yaitu penerapan prinsip e-procurement dalam pengadaan barang dan jasa pemerintah. Penerapan prinsip e-procurement dalam pengadaan barang dan jasa pemerintah berdasarkan Perpres 54 tahun 2010, yaitu efisiensi, efektifitas, adil dan tidak diskriminatif, terbuka dan bersaing, transparan, akuntabilitas. (2) Variabel Terikat (Dependent Variable).
Dalam penelitian ini yang menjadi variabel terikat yakni Ketahanan Tata Pemerintahan Daerah di Kabupaten Penajam Paser Utara. Ketahanan tata pemerintahan daerah bisa dikaitkan dengan kemampuan pemerintah daerah dalam mencapai tujuan e-procurement berdasarkan Perpres 54 tahun 2010.

Analisis data yang digunakan adalah: (1) Analisis Data Kuantitatif. Data yang terkumpul dianalisis dengan teknik deskriptif yakni menyajikan hasil perhitungan statistik deskriptif berupa tabel frekuensi dan persentase yang didapat dari hasil penelitian. Dalam menganalisis data yang telah terkumpul dilakukan beberapa langkah yaitu penyuntingan data, pemberian kode, dan tabulasi. (2) Analisis Data Kualitatif. Data yang terkumpul dianalisis dengan alat analisis yaitu prinsipprinsip penerapan e-procurement berdasarkan Perpres 54 Tahun 2010 tentang Pengadaan Barang dan Jasa Pemerintah. Dalam penelitian ini, data yang telah terkumpul akan diolah. Proses ini terdiri dari tiga sub proses yang saling berkaitan yaitu data reduction, data display, dan conclusion drawing/verification (Miles dan Huberman, 1992:15-20).

\section{PEMBAHASAN}

\section{Logistik}

Konteks logistik identik dengan organisasi, pergerakan, dan penyimpanan dari material dan manusia. Domain dari aktivitas logistik sendiri adalah menyediakan sistem dengan produk yang tepat, di lokasi yang tepat, pada waktu yang tepat (right product, in the right place, at the right time) dengan mengoptimasikan pengukuran performansi yang diberikan contohnya meminimalisir total biaya operasional dan memenuhi kualifikasi yang diberikan sesuai dengan kemampuan dari 
klien dan sesuai dengan kualitas pelayanan (Ghiani, 2004).

Dalam Cetak Biru Pengembangan Sistem Logistik Nasional (Perpres No. 26 Tahun 2012), logistik didefinisikan sebagai bagian dari rantai pasok (supply chain) yang menangani arus barang, informasi, dan uang melalui proses pengadaan (procurement), penyimpanan (warehousing), transportasi (transportation), distribusi (distribution), dan pelayanan pengantaran (delivery services). Adapun penyusunan sistem logistik ditujukan untuk meningkatkan keamanan, efisiensi, dan efektfitas pergerakan barang, informasi, dan uang mulai dari titik asal (point of origin) sampai dengan titik tujuan (point of destination) sesuai dengan jenis, kualitas, jumlah, waktu dan tempat yang dikehendaki konsumen.

\section{Pengadaan Barang dan Jasa Pemerintah}

Pengadaan barang dan jasa (procurement) pada hakikatnya merupakan upaya untuk mendapatkan atau mewujudkan barang dan jasa yang diinginkan dengan menggunakan metode dan proses tertentu untuk mencapai kesepakatan harga, waktu, dan kesepakatan lainnya. Pengadaan dilakukan atas dasar pemikiran yang logis dan sistimatis, mengikuti norma dan etika yang berlaku, berdasarkan metoda dan proses pengadaan yang baku (Indonesia, 2005:5). Kegiatan pengadaan barang dan jasa ini dituangkan dalam suatu perjanjian atau kontrak pengadaan barang dan jasa.

Pengertian pengadaan barang dan jasa menurut Sutedi (2012:7) yaitu mencakup penjelasan dari seluruh proses sejak awal perencanaan, persiapan, perijinan, penentuan pemenang lelang hingga tahap pelaksanaan dan proses administrasi dalam pengadaan barang, pekerjaan atau jasa seperti jasa konsultasi teknis, jasa konsultasi keuangan, jasa konsultasi hukum atau jasa lainnya. Hal ini hampir sama dengan penjelasan dalam Peraturan Presiden Nomor 54 Tahun 2010, bahwa pengadaan barang/jasa pemerintah adalah kegiatan untuk memperoleh barang dan jasa oleh Kementerian/Lembaga/Satuan Kerja Perangkat Daerah/Institusi lainnya yang prosesnya dimulai dari perencanaan kebutuhan sampai diselesaikannya seluruh kegiatan untuk memperoleh barang dan jasa.

Berdasarkan Keputusan Presiden Nomor 54 Tahun 2010 tentang Pedoman Pengadaan Barang Dan Jasa Pemerintah, Prinsip-prinsip yang menjadi dasar dalam pelaksanaan kegiatan pengadaan barang dan jasa pemerintah yaitu efisien, efektif, terbuka dan bersaing, transparan, adil/tidak diskriminatif, dan akuntabel.

\section{Teori e-Procurement}

e-Procurement menurut Sutedi (2012:254) adalah sebuah sistem lelang dalam pengadaan barang dan jasa pemerintah dengan memanfaatkan teknologi, informasi dan komunikasi berbasis internet, agar dapat berlangsung secara efektif, efisien, terbuka, dan akuntabel. Hal ini hampir sama dengan penjelasan dari Indrajit yang dikutip oleh Andrianto (2007:218) bahwa e-procurement diartikan sebagai sebuah proses digitalisasi tender atau lelang pengadaan barang dan jasa pemerintah berbantuan internet. Definisi lebih sederhana disampaikan oleh Andrianto (2007:215), bahwa e-procurement adalah proses pengadaan barang dan jasa yang dilakukan melalui lelang secara elektronik.

Pengadaan barang dan jasa pemerintah secara elektronik atau via internet (e-procurement) merupakan salah satu 
Rahmat Hidayat -- Penerapan E-Procurement Dalam Proses Pengadaan Barang Dan Jasa Pemerintah Guna Mendukung Ketahanan Tata Pemerintahan Daerah (Studi Pada Unit Layanan Pengadaan Barang Dan Jasa Pemerintah Kabupaten Penajam Paser Utara Provinsi Kalimantan Timur)

mekanisme mewujudkan nilai-nilai good governance. Menurut Oliviera e-procurement adalah proses pembelian barang dan jasa yang diperlukan bagi kebutuhan operasional organisasi secara elektronik (Djojosoekarto, 2008:10). e-Procurement dalam pengertian umum diterapkan pada sistem data base yang terintegrasi dan area luas yang berbasis internet dengan jaringan sistem komunikasi dalam sebagian atau seluruh proses pembelian.

\section{Ketahanan Tata Pemerintahan Daerah Dalam Pengadaan Barang dan Jasa Pemerintah}

Ketahanan tata pemerintahan daerah merupakan derivat dari ketahanan nasional, ketahanan tata pemerintahan daerah dapat diartikan sebagai kondisi dinamik suatu pemerintahan daerah yang meliputi segenap aspek kehidupan yang terintegrasi serta berisi keuletan dan ketangguhan yang mengandung kemampuan untuk mengembangkan kekuatan daerahnya dalam menghadapi dan mengatasi segala tantangan, ancaman, hambatan, dan gangguan yang datang dari luar negeri atau dari dalam negeri guna menjamin identitas, integritas, serta kelangsungan hidup bangsa dan negara dalam mencapai tujuan daerah dan tujuan nasional.

Pelaksanaan e-procurement yang tangguh dapat terwujud apabila dalam pelaksanaannya mampu memenuhi tujuan dari penerapan e-procurement sesuai Perpres No. 54 tahun 2010. Tujuan tersebut bisa dijadikan salah satu indikator dalam ketahanan tata pemerintahan daerah, sebagaimana dijelaskan dalam Peraturan Presiden Nomor 54 Tahun 2010 tentang Pengadaan Barang dan Jasa Pemerintah pada Pasal 107, yaitu: meningkatkan transparansi dan akuntabilitas; meningkatkan akses pasar dan persaingan usaha yang sehat; memperbaiki tingkat efisiensi proses pengadaan; mendukung proses monitoring dan audit; memenuhi kebutuhan akses informasi yang realtime.

\section{Penerapan Prinsip e-Procurement Di Kabupaten Penajam Paser Utara}

Tabel 1 menunjukkan frekuensi pilihan jawaban dari responden untuk prinsip-prinsip dalam penerapan e-procurement di Kabupaten Penajam Paser Utara. Pilihan jawaban tertinggi yaitu jawaban setuju sebesar 2420 atau 68,81 persen, kemudian diikuti jawaban sangat setuju sebesar 650 atau 18,48 persen, jawaban raguragu sebesar 375 atau 10,66 persen, dan jawaban tidak setuju sebesar 72 atau 2,05 persen.

Hasil perhitungan tingkat persepsi responden menunjukkan angka sebesar 3517 atau 78,50 persen. Angka ini jika dikonversi pada skala interval maka terletak pada rentang lebih dari 2390 artinya menurut responden penerapan prinsip e-procurement di Kabupaten Penajam Paser Utara berada pada kondisi tinggi.

\section{Kendala Penerapan e-Procurement Di Kabupaten Penajam Paser Utara}

Tabel 2 menunjukkan frekuensi pilihan jawaban dari responden untuk kendala dalam penerapan e-procurement di Kabupaten Penajam Paser Utara. Pilihan jawaban tertinggi yaitu jawaban setuju sebesar 636 atau 66,60 persen, kemudian diikuti jawaban ragu-ragu sebesar 156 atau 16,34 persen, jawaban tidak setuju sebesar 148 atau 15,50, dan sangat setuju sebesar 15 atau 1,57 persen.

Hasil perhitungan tingkat persepsi responden menunjukkan angka sebesar 955 atau 66,32 persen. Angka ini jika dikonversi pada skala interval maka terletak pada 
rentang lebih dari 768 artinya menurut responden bahwa kendala dalam penerapan e-procurement di Kabupaten Penajam Paser Utara berada pada kondisi tinggi.

\section{Strategi Dalam Mengatasi Kendala}

Pertama, Kelembagaan ULP yang Berdiri Sendiri. Berdasarkan temuan lapangan, ULP yang dibentuk melekat pada unit yang sudah ada membawa dampak yang kurang baik bagi kelancaran kebijakan e-procurement. Oleh karena itu, sudah saatnya Pemerintah Kabupaten Penajam Paser Utara memiliki ULP yang bersifat permanen dan dapat berdiri sendiri. Berdiri sendiri maksudnya adalah ULP dibentuk dalam unit struktural tersendiri yang pembentukannya berpedoman kepada Peraturan Pemerintah No. 41 Tahun 2007 tentang Organisasi Perangkat Daerah. Dengan demikian ULP dapat diisi oleh orang-orang yang profesional dan berkompetensi tinggi karena bekerja sesuai dengan tupoksinya sehingga proses pengadaan secara elektronik dapat lebih efektif, efesien, bertanggung jawab dan transparan.

Kedua, Peningkatan Infrastruktur Pendukung e-Procurement. ULPdi Kabupaten PPU telah dibekali dengan fasilitas yang cukup memadai, kendati demikian masih perlu dibenahi atau ditingkatkan fasilitasnya guna mendukung peningkatan kinerja para pegawai. Fasilitas infrastruktur pendukung yang perlu ditingkatkan yaitu penyediaan mesin generator khusus, komputer untuk setiap anggota disertai scanner dan penghancur kertas, fasilitas konektifitas internet, pembuatan sekat antar komputer di ruangan bidding room, seluruh ruangan ULP sebaiknya dilengkapi oleh CCTV agar mempermudah monitoring dan evaluasi dalam penyelenggaraan e-procurement.

Ketiga, Pengembangan SDM. Sistem e-procurement yang dibangun tidak secara otomatis mengubah budaya kerja para pengelola e-procurement. Agar transparansi berhasil diwujudkan melalui e-procurement maka mental manusia yang menyelenggarakan sistem e-procurement ini harus dibangun agar memiliki kapasitas, kapabilitas, dan komitmen yang kuat serta integritas dalam mengimplementasikan e-procurement sebagaimana yang diamanahkan dalam peraturan-peraturan.

\section{Penerapan e-Procurement Dan Ketahanan Tata Pemerintahan Daerah}

Berdasarkan penelitian yang telah dilakukan, dapat diketahui kondisi perwujudan

Tabel 1 Analisis Penerapan Prinsip e-Procurement

\begin{tabular}{lcccccc}
\hline \multirow{2}{*}{ Variabel } & STS & TS & $\mathbf{R}$ & $\mathbf{S}$ & SS & \multirow{2}{*}{ Total } \\
\cline { 2 - 5 } & $\mathbf{1}$ & $\mathbf{2}$ & $\mathbf{3}$ & $\mathbf{4}$ & $\mathbf{5}$ & \\
\hline Efisiensi & 0 & 0 & 8 & 104 & 48 & 160 \\
Efektifitas & 0 & 8 & 53 & 91 & 8 & 160 \\
Adil dan Tidak Diskriminatif & 0 & 14 & 12 & 87 & 15 & 128 \\
Transparansi & 0 & 0 & 9 & 107 & 12 & 128 \\
Terbuka dan Bersaing & 0 & 10 & 27 & 124 & 31 & 192 \\
Akuntabilitas & 0 & 4 & 16 & 92 & 16 & 128 \\
Jumlah & 0 & 36 & 125 & 605 & 130 & 896 \\
Total (Skor x Jumlah) & 0 & 72 & 375 & 2420 & 650 & $\mathbf{3 5 1 7}$ \\
Persentase & 0 & 2,05 & 10,66 & 68,81 & 18,48 & 100 \\
\hline
\end{tabular}

Sumber: Data 2014 (Diolah) 
Rahmat Hidayat -- Penerapan E-Procurement Dalam Proses Pengadaan Barang Dan Jasa Pemerintah Guna Mendukung Ketahanan Tata Pemerintahan Daerah (Studi Pada Unit Layanan Pengadaan Barang Dan Jasa

Pemerintah Kabupaten Penajam Paser Utara Provinsi Kalimantan Timur)

Tabel 2 Analisis Kendala Penerapan e-Procurement

\begin{tabular}{lcccccc}
\hline \multirow{2}{*}{ Variabel } & STS & TS & R & S & SS & \multirow{2}{*}{ Total } \\
\cline { 2 - 5 } & $\mathbf{1}$ & $\mathbf{2}$ & $\mathbf{3}$ & $\mathbf{4}$ & $\mathbf{5}$ & \\
\hline Kelembagaan ULP & 0 & 1 & 3 & 25 & 3 & 32 \\
Infrastruktur & 0 & 21 & 14 & 61 & 0 & 96 \\
SDM & 0 & 52 & 35 & 73 & 0 & 160 \\
Jumlah & 0 & 74 & 52 & 159 & 3 & 288 \\
Total (Skor x Jumlah) & 0 & 148 & 156 & 636 & 15 & 955 \\
Persentase & 0 & 15,50 & 16,34 & 66,60 & 1,57 & 100 \\
\hline
\end{tabular}

Sumber: Data 2014 (Diolah)

penerapan e-procurement dalam mendukung ketahanan tata pemerintahan daerah di Kabupaten Penajam Paser Utara, yaitu sebagai berikut:

Pertama, Meningkatkan Transparansi dan Akuntabilitas. Penerapan e-procurement dalam pengadaan barang dan jasa di Kabupaten Penajam Paser Utara telah menunjukkan adanya peningkatan transparansi dan akuntabilitas dibanding pengadaan barang dan jasa secara manual. Peningkatan transparansi dan akuntabilitas dapat dilihat dari persepsi positif para responden dan informan mengenai penerapan indikator transparansi dan akuntabilitas yakni sebesar 80,47 persen dan 78,75 persen sehingga masuk dalam kategori tinggi. Artinya para responden menyetujui bahwa prinsip transparansi dan akuntabilitas telah dilaksanakan dalam e-procurement di Kabupaten Penajam Paser Utara.

Kedua, Meningkatkan Akses Pasar dan Persaingan Usaha yang Sehat. Penerapan e-procurement di Kabupaten Penajam Paser Utara telah mampu meningkatkan persaingan usaha yang sehat diantara para penyedia barang dan jasa. Hal ini ditandai dengan penerapan salah satu prinsip e-procurement yakni prinsip terbuka dan bersaing. Berdasarkan hasil kuesioner dan wawancara menunjukkan prinsip terbuka dan bersaing telah dilaksanakan dalam proses e-procurement di Kabupaten Penajam Paser Utara. Persepsi para responden dan informan menyatakan setuju bahwa penerapan prinsip terbuka dan bersaing telah dilaksanakan dengan baik, dengan persentase indikator sebesar 78,33 persen.

Ketiga, Memperbaiki Tingkat Efisiensi Proses Pengadaan. Berdasarkan hasil penyebaran kuesioner dan wawancara, dapat diketahui persepsi para responden dan informan mengenai penerapan prinsip e-procurement menyatakan setuju bahwa e-procurement telah mampu menciptakan efisiensi dalam pengadaan barang dan jasa pemerintah, dengan persentase indikator sebesar 85 persen. Indikator prinsip efisiensi dalam e-procurement yaitu biaya proses dan administrasi semakin efisien, kecepatan dalam pengadaan barang dan jasa, kemudahan dalam pengadaan barang dan jasa, penghematan anggaran, serta capaian hasil dan sasaran dengan kualitas yang maksimum.

Keempat, Mendukung Proses Monitoring dan Audit. Berdasarkan hasil penelitian di Kabupaten Penajam Paser Utara, tujuan e-procurement untuk mendukung proses monitoring dan audit telah tercapai. Hal ini ditandai bahwa semua data mengenai pengadaan barang dan jasa atau biasa disebut lelang, akan tersimpan terus dalam Sistem Pengadaan Barang dan Jasa (SPSE) dan website, sehingga memudahkan KPK, BPK, Lembaga Kebijakan Pengadaan Barang 
dan jasa Pemerintah (LKPP), BPKP, dan Inspektorat untuk mengawasi dan memeriksa pengadaan barang dan jasa atau lelang.

Kelima, Memenuhi Kebutuhan Akses Informasi secara Real Time. Sesuai hasil penelitian di Kabupaten Penajam Paser Utara, tujuan e-procurement untuk memenuhi kebutuhan akses informasi yang realtime telah tercapai. Hal ini dapat dilihat dari pengadaan melalui e-procurement, informasi yang diperlukan tentang pengadaan barang dan jasa dapat diperoleh setiap saat. Semua pihak dengan mudah dapat mengakses portal pengadaan melalui media internet.

\section{SIMPULAN}

Berdasarkan uraian di atas dapat ditarik simpulan sebagai berikut:

Pertama, penerapan prinsip e-procurement di Kabupaten Penajam Paser Utara secara umum sudah berjalan sesuai peraturan yang berlaku namun masih terdapat beberapa kendala dalam penerapannya. Hal ini terlihat dari hasil pengujian penerapan prinsip e-procurement kepada 32 orang anggota ULP Kabupaten PPU menggunakan skala Likert. Mayoritas responden menyatakan setuju bahwa prinsip-prinsip e-procurement telah diterapkan dalam pelaksanaan e-procurement di Kabupaten Penajam Paser Utara, dengan rata-rata persentase indikator sebesar 78,50 persen dan berada pada kondisi tinggi.

Kedua, kendala-kendala yang dihadapi dalam penerapan e-procurement di Kabupaten Penajam Paser Utara, adalah permasalahan kelembagaan ULP, keterbatasan infrastruktur e-procurement, dan kendala sumber daya manusia. Strategi dalam mengatasi kendala penerapan e-procurement guna mendukung ketahanan tata pemerintahan daerah di
Kabupaten Penajam Paser Utara, yakni: kelembagaan ULP yang berdiri sendiri, peningkatan infrastruktur pendukung e-procurement, dan pengembangan SDM.

Ketiga, adapun wujud e-procurement dalam mendukung ketahanan tata pemerintahan daerah yaitu: meningkatkan transparansi dan akuntabilitas; meningkatkan akses pasar dan persaingan usaha yang sehat; memperbaiki tingkat efisiensi proses pengadaan; mendukung proses monitoring dan audit; memenuhi kebutuhan akses informasi yang real time.

Keempat, Pemerintah Kabupaten Penajam Paser Utara bisa dikatakan berhasil menerapkan prinsip serta mencapai tujuan e-procurement, akan tetapi masih terdapat beberapa kendala dalam pelaksanaannya. Oleh karena itu, ketahanan tata pemerintahan daerah di Kabupaten Penajam Paser Utara dikategorikan cukup tangguh.

Selanjutnya direkomendasikan hal-hal sebagai berikut:

Pertama, ULP Kabupaten Penajam Paser Utara adalah lembaga ad hoc yang dibentuk melekat pada unit yang sudah ada, yaitu bagian pembangunan sekretariat Kabupaten PPU. Hal ini membawa dampak yang kurang baik bagi kelancaran kebijakan e-procurement. Oleh karena itu, sudah saatnya Pemerintah Kabupaten Penajam Paser Utara memiliki ULP yang bersifat permanen dan dapat berdiri sendiri. Dengan demikian ULP dapat diisi oleh orang-orang yang profesional dan berkompetensi tinggi karena bekerja sesuai dengan tupoksinya sehingga proses pengadaan secara elektronik dapat lebih efektif, efesien, bertanggung jawab dan transparan.

Kedua, perlu ditingkatkan pelaksanaan komunikasi baik antar Satuan Kerja Perangkat Daerah (SKPD) maupun peserta penyedia 
Rahmat Hidayat -- Penerapan E-Procurement Dalam Proses Pengadaan Barang Dan Jasa Pemerintah Guna Mendukung Ketahanan Tata Pemerintahan Daerah (Studi Pada Unit Layanan Pengadaan Barang Dan Jasa Pemerintah Kabupaten Penajam Paser Utara Provinsi Kalimantan Timur)

barang dan jasa/masyarakat secara luas dalam pelaksanaan e-procurement dimana informasi harus disampaikan dengan sejelas-jelasnya, setepat-tepatnya dan seakurat mungkin serta dapat dipahami agar tidak terjadi penyimpangan-penyimpangan.

Ketiga, dalam rangka pelaksanaan tugas selalu memperhatikan peraturan-peraturan yang berlaku, selalu memperhatikan dan mengevaluasi sumber daya aparatur serta selalu diupayakan peningkatan-peningkatan dan kemampuan agar dalam pelaksanaan setiap tugas baik yang berkaitan dengan pelaksanaan e-procurement maupun tugas lain dapat dihandalkan sebagai suatu sumber kekuatan yang positif dalammencapai good governance sehingga dapat mewujudkan ketangguhan dalam ketahanan tata pemerintahan daerah.

\section{DAFTAR PUSTAKA}

Andrianto, Nico, 2007, Good e-Government: Transparansi dan Akuntabilitas Publik Melalui e-Government. Malang: Banyumedia Publishing.

Arikunto, Suharsimi, 2008, Metodelogi penelitian, Yogyakarta: Bina Aksara.

Djojoesoekarto, Agung, 2008, e-Procurement di Indonesia, Pengembangan Layanan Pengadaan Barang dan Jasa Pemerintah Secara Elektronik, Jakarta : Kemitraan. Ghiani, G., Laporte, G., \& Musmanno, R., 2004,Introduction to Logistics Systems Planning and Control, England: John Wiley.

Indonesia, 2005, Prinsip Dasar Kebijakan \& Kerangka Hukum Pengadaan Barang \& Jasa, Jakarta : Indonesian Procurement Watch.

Miles, Matthew dan Huberman, A. Michael, 1992, Analisis Data Kualitatif: Buku
Sumber Tantang Metode-Metode Baru. Jakarta:UI Press.

Narbuko,Cholid \& H.Abu Achmadi. 2005. Metodologi Penelitian. Jakarta: Bumi Aksara.

Subagyo, P. Joko, 2006, Metode Penelitian Dalam Teori Dan Praktek, Jakarta: Rineka Cipta

Sukmadinata, Nana S., 2007, Landasan Psikologi Proses Pendidikan. Bandung: Remaja Rosdakarya.

Sutedi, Adrian, 2012, Aspek Hukum Pengadaan Barang \& Jasa dan Berbagai Permasalahannya. Ed. 2, Jakarta: Sinar Grafika.

\section{Undang-Undang dan Peraturan:}

UU.No.7 Tahun 2002

Peraturan Presiden Republik Indonesia Nomor 54 Tahun 2010

Peraturan Presiden Republik Indonesia Nomor 26 Tahun 2012

Peraturan Pemerintah No. 45 Tahun 2007.

\section{Internet:}

http://www.korankaltim.com/pemkab-ppusempurnakan-e-procurement/(diakses 20 Juni 2014)

http://m.inilah.com/news/detail/1777007/ oknum-ulp-ppu-diduga-atur-pemenanglelang(diakses pada tanggal 5 November 2014)

https://harianmahakam.wordpress. com/2014/10/25/dprd-penajam-paserutara-intervensi-layanan-pengadaansecara-elektronik-lpse/. (diakses pada tanggal 5 November 2014)

http://www.korankaltim.com/sejumlah-lelangproyek-lamban/. (diakses pada tanggal 5 November 2014) 


\begin{tabular}{lll}
\hline VOLUME 21 & No. 2, 25 Agustus 2015 & Halaman 128-141 \\
\hline
\end{tabular}

\title{
PERAN PEMUDA DALAM MENGEMBANGKAN \\ ECO EDU WISATA MANGROVE DAN IMPLIKASINYA TERHADAP \\ KETAHANAN LINGKUNGAN DAERAH \\ (Studi Pada Perkumpulan Pemuda Peduli Lingkungan "Prenjak" \\ Dusun Tapak, Kelurahan Tugurejo, Kecamatan Tugu, Kota Semarang, \\ Provinsi Jawa Tengah)
}

\author{
Fitriyani \\ Program Studi Ketahanan Nasional \\ Universitas Gadjah Mada \\ E-mail : fitri_fee88@yahoo.com
}

\begin{abstract}
This study aimsed to reviewed the role of youth in developing Edu Eco Tourism Mangrove and to reviewed the implications in the developing of Edu Eco Tourism Mangrove by youth towards environmental resilience in the region of Tapak Village, Sub-district Tugurejo, District Tugu, City of Semarang, Central Java. This research used descriptive qualitative method. The research approach used in this study was the study on problems occuring in the society. Researcher also used observation, in-depth interviews, and documentation study to collected data. The research's result showed that Prenjak had roles and contributions in developing Edu Eco Tourism Mangrove Tapak Tugurejo. Prenjak's role were measured by the indicators of the development of ecotourism mangrove, that consist of management program ecotourism, society's support, infrastructures, and resource utilization. The development of Edu Eco Tourism Mangrove had implications to the regional enviromental resilience, indicated by ecosystem availability, the minimum of power consumption, management of waste and pollutants, sustainability of the local socio culture system, and also the understanding of live environment concept.
\end{abstract}

Keywords: Youth Role, Edu Eco Tourism Mangrove, Regional Environmental Resilience

\begin{abstract}
ABSTRAK
Penelitian ini bertujuan untuk mengkaji peran pemuda dalam mengembangkan Eco Edu Wisata Mangrove dan untuk mengkaji implikasi pengembangan Eco Edu Wisata Mangrove oleh pemuda terhadap ketahanan lingkungan daerah di Dusun Tapak, Kelurahan Tugurejo, Kecamatan Tugu, Kota Semarang, Provinsi Jawa Tengah. Penelitian ini menggunakan metode deskriptif kualitatif. Pendekatan penelitian yang digunakan adalah studi pada suatu permasalahan yang terjadi di masyarakat. Pengumpulan data dalam penelitian ini menggunakan observasi, wawancara mendalam dan studi dokumentasi. Hasil penelitian menunjukkan bahwa Prenjak berperan dalam mengembangkan Eco Edu Wisata Mangrove Tapak Tugurejo. Adapun peran Prenjak dalam pengembangan Eco Edu Wisata Mangrove meliputi program pengelolaan ekowisata, dukungan masyarakat, sarana prasarana, dan penggunaan lahan. Peran pemuda Prenjak dalam mengembangkan Eco Edu Wisata Mangrove berimplikasi terhadap ketahanan lingkungan daerah di Dusun Tapak meliputi ketersediaan ekosistem, pengendalian limbah dan pencemaran, kelanjutan sistem sosial budaya lokal, dan peningkatan pemahaman konsep lingkungan hidup.
\end{abstract}

Kata Kunci: Peran Pemuda, Eco Edu Wisata Mangrove, Ketahanan Lingkungan Daerah 
Fitriyani -- Peran Pemuda Dalam Mengembangkan Eco Edu Wisata Mangrove Dan Implikasinya Terhadap Ketahanan Lingkungan Daerah (Studi Pada Perkumpulan Pemuda Peduli Lingkungan "Prenjak" Dusun Tapak, Kelurahan Tugurejo, Kecamatan Tugu, Kota Semarang, Provinsi Jawa Tengah)

\section{PENGANTAR}

Penduduk Indonesia yang besar memberi tekanan besar pula pada lingkungan hidup. Pembangunan yang pesat menghasilkan produk sampingan negatif berupa pencemaran dan kerusakan lingkungan. Indonesia sebagai negara berkembang, mempunyai kerusakan lingkungan yang makin bertambah akibat aspek kesadaran lingkungan yang rendah. Kerusakan dan degradasi ekosistem mangrove saat ini merupakan masalah umum di berbagai negara, terutama negara-negara berkembang dan miskin. Kerusakan ini terutama disebabkan oleh konversi lahan untuk pemukiman, pertambakan, pengambilan kayu dan sebagainya, yang tidak mempertimbangkan kelestarian lingkungan hidup (Nugroho, 2011).

Kondisi hutan mangrove di pesisir Kota Semarang sejak lama mengalami degradasi secara luas, akibat dari abrasi dan perubahan lahan. Kelurahan Tugurejo terletak di wilayah pesisir Semarang bagian barat dengan mayoritas masyarakatnya bermata pencaharian sebagai petani tambak. Abrasi terjadi pada pesisir Laut Jawa, maka secara langsung masyarakat mengalami dampak negatif. Permasalahan yang muncul antara lain tergerusnya daratan yang mengakibatkan penyempitan luasan tambak, abrasi dan rob yang menyebabkan hilangnya tambak serta menurunnya kualitas air tambak secara drastis sehingga menyebabkan kuantitas dan kualitas produksi tambak menurun (Ermiliansa dkk., 2014).

Kondisi lingkungan akibat pembangunan belasan industri di sekitar wilayah kelurahan tersebut telah memperburuk keadaan karena keluaran limbah industri berupa limbah kimia. Sungai Tapak yang berada di wilayah tersebut merupakan andalan dalam penyediaan air tawar dan saluran irigasi pertanian, saat ini telah tercemar limbah rumah tangga dan limbah industri. Kondisi ini menyebabkan kualitas air menurun dan membahayakan ikan-ikan yang dibudidayakan dalam tambak (Ermiliansa dkk., 2014).

Upaya konservasi hutan mangrove yang telah dilakukan oleh pemuda dan masyarakat sekitar serta kesesuaian yang dimiliki oleh kawasan mangrove Dusun Tapak untuk dijadikan kawasan Eco Edu Wisata apabila direalisasikan, dapat membantu pengembangan pariwisata di Kota Semarang. Pemilihan lokasi di Dusun Tapak, karena Dusun Tapak merupakan salah satu pusat pembudidayaan mangrove di Provinsi Jawa Tengah dan telah dirintis serta dikembangkan sebagai embrio Eco Edu Wisata Mangrove. Selain itu, sumberdaya manusia pemuda yang dimiliki sangat berpotensi untuk dikembangkan. Pemuda Prenjak sebagai lembaga swadaya yang sudah mengelola mangrove secara turun temurun, dengan berbagai keterbatasannya saat ini sedang berupaya mengembangkan kawasan Eco Edu Wisata tersebut. Dusun Tapak memiliki hutan yang gersang dan belum dilirik oleh masyarakat sebelum adanya aksi Prenjak tersebut. Adanya berbagai faktor yang mempengaruhi peran pemuda dalam mengembangkan Eco Edu Wisata Mangrove dan implikasinya terhadap ketahanan lingkungan daerah menjadi kajian yang menarik untuk diteliti.

Penelitian ini dilakukan dengan tujuan: (1) Untuk mengkaji peran peran pemuda Prenjak dalam mengembangkan Eco Edu Wisata Mangrove di Dusun Tapak, Kelurahan Tugurejo, Kecamatan Tugu, Kota Semarang. (2) Untuk mengkaji implikasi pengembangan 
Eco Edu Wisata Mangrove oleh pemuda Prenjak terhadap ketahanan lingkungan daerah di Dusun Tapak, Kelurahan Tugurejo, Kecamatan Tugu, Kota Semarang.

Penelitian ini adalah penelitian deskriptif kualitatif yang bertujuan untuk menggambarkan suatu fenomena, karakteristik, situasi atau kejadian secara sistematis sebagaimana adanya, dengan tetap berpedoman pada kualitas data yang faktual dan akurat. Pendekatan penelitian yang digunakan adalah studi pada suatu permasalahan yang terjadi di lapangan. Studi yang menjadi obyek dalam penelitian ini adalah peran pemuda Prenjak dalam mengembangkan Eco Edu Wisata Mangrove Tapak Tugurejo. Penelitian ini dilaksanakan di Provinsi Jawa Tengah yaitu Dusun Tapak, Kelurahan Tugurejo, Kecamatan Tugu, Kota Semarang. Teknik pengumpulan data menggunakan observasi non partisipatif di mana peneliti tidak terlibat langsung sebagai objek yang diamati atau diteliti. Observasi dilakukan dengan live in di Sekretariat Prenjak yang dilaksanakan pada 10-30 Desember 2014.

Pengumpulan data melalui wawancara mendalam dalam penelitian ini dilakukan dengan menggunakan pedoman wawancara (interview guide) dengan jawaban terbuka yang dirancang oleh peneliti. Informan dalam penelitian ini ditentukan melalui purposive sampling. Dokumentasi dilakukan oleh peneliti dengan mengumpulkan foto-foto kegiatan Prenjak dalam Eco Edu Wisata Mangrove, catatan transkrip, buku, majalah, surat kabar, dan sebagainya. Analisis data yang digunakan peneliti yaitu reduksi data, display data, dan mengambil kesimpulan atas data-data tersebut.

\section{PEMBAHASAN}

Faktor Pendorong Peran Pemuda dalam Mengembangkan Eco Edu Wisata Mangrove Tapak Tugurejo

Eco Edu Wisata merupakan gabungan antara ekowisata dan eduwisata. Definisi ekowisata pertama kali diperkenalkan oleh organisasi The International Ecotourism Society atau TIES dalam (Fandeli, 2000), menjelaskan bahwa ekowisata adalah bentuk perjalanan wisata ke area alami yang dilakukan dengan tujuan mengkonservasi lingkungan dan melestarikan kehidupan dan kesejahteraan penduduk setempat. Eduwisata dimaksudkan sebagai suatu program di mana peserta kegiatan wisata melakukan perjalanan wisata pada suatu tempat tertentu dalam suatu kelompok dengan tujuan utama mendapatkan pengalaman belajar secara langsung terkait dengan lokasi yang dilindungi (Rodger, 1998).

EcoEdu Wisata merupakan pengembangan wisata yang menghargai kaidah-kaidah alam dengan melaksanakan program pembangunan dan pelestarian secara terpadu antara upaya konservasi sumberdaya alam yang dilakukan dengan melaksanakan program pembangunan yang memperhatikan kualitas daya dukung lingkungan dan ramah lingkungan. Konsep Eco Edu Wisata Mangrove (EEWM) ini merupakan salah satu alternatif untuk pengembangan kawasan pariwisata dalam suatu wilayah pesisir yang tetap memperhatikan konservasi mangrove dengan menggunakan sumberdaya serta budaya masyarakat lokal. Eco Edu Wisata berperan dalam menjaga fungsi lindung pada kawasan konservasi sebagai obyek wisata bahari berbasis masyarakat melalui wisata pendidikan, penelitian, dan pengembangan (litbang) serta wisata minat khusus (DKP Kota Semarang, 2012). 
Fitriyani -- Peran Pemuda Dalam Mengembangkan Eco Edu Wisata Mangrove Dan Implikasinya Terhadap Ketahanan Lingkungan Daerah (Studi Pada Perkumpulan Pemuda Peduli Lingkungan "Prenjak" Dusun Tapak, Kelurahan Tugurejo, Kecamatan Tugu, Kota Semarang, Provinsi Jawa Tengah)

Ekosistem mangrove adalah suatu sistem di alam tempat berlangsungnya kehidupan yang mencerminkan hubungan timbal balik antara makhluk hidup dengan lingkungannya dan di antara makhluk hidup itu sendiri, terdapat pada wilayah pesisir, terpengaruh pasang surut air laut, dan didominasi oleh spesies pohon atau semak yang khas dan mampu tumbuh dalam perairan asin/ payau (Santoso, 2000). Disebutkan bahwa faktor-faktor yang mempengaruhi pengembangan ekowisata mangrove yaitu program pengelolaan ekowisata, dukungan masyarakat, sarana dan prasarana, dan penggunaan lahan.

Peran pemuda Prenjak dalam mengembangkan EEWM Tapak Tugurejo lahir dari sebuah proses yang panjang dan terus berkembang hingga saat ini. Prenjak merupakan organisasi yang memfokuskan kegiatannya di kawasan pesisir guna melakukan kegiatan konservasi dan penyelamatan habitat khususnya hutan mangrove. Perkembangan kegiatan memunculkan ide untuk membuat daerah yang sudah direhabilitasi menjadi kawasan wisata. Berdasarkan data yang diperoleh di lapangan, faktor pendorong pemuda berperan mengembangkan Dusun Tapak sebagai kawasan EEWM dikelompokkan menjadi 2 (dua) yakni faktor intrinsik (faktor yang berasal dari dalam diri pemuda) dan faktor ekstrinsik (faktor yang berasal dari luar diri pemuda).

Faktor intrinsik yaitu (1) semangat dan motivasi jiwa sosial, idealisme, dan komitmen melakukan kegiatan yang bermanfaat guna membangun Dusun Tapak; (2) keinginan untuk belajar dikarenakan mayoritas pemuda putus sekolah dan sebagai sarana meningkatkan kepercayaan diri. (3) Kesempatan mendapatkan beasiswa paket B, C, dan pendidikan di Perguruan Tinggi serta pengalaman organisasi;
(4) harapan menjadikan kondisi Dusun Tapak lebih baik; dan (5) kecintaan pada Dusun Tapak dan lingkungan sekitarnya. Faktor ekstrinsik yaitu (1) kondisi lingkungan di Dusun Tapak semakin memprihatinkan seperti pencemaran limbah, sampah, abrasi, dan banjir rob; (2) pengangguran dan kemiskinan yang terus meningkat; (3) kesenjangan sosial dan disfungsional kepengurusan RW sehingga ada keinginan menyatukan kelompok-kelompok masyarakat; dan (4) isu reklamasi.

\section{Aktor Pengelola Kawasan EEWM Tapak Tugurejo}

Kawasan EEWM Tapak Tugurejo dikelola secara swadaya oleh Prenjak dan terdapat kelompok-kelompok masyarakat yang bersinergi membantu Prenjak dalam pengembangan EEWMTapak Tugurejo. Prenjak berperan dalam penguatan kelembagaan di Dusun Tapak. Sinergi yang terbangun sangat berguna bagi pengembangan EEWM Tapak Tugurejo. Prenjak sebagai pencetus, pelopor, penggerak, dan pemimpin di antara kelompokkelompok tersebut. Kelompok-kelompok tersebut yakni:

Pertama, Kelompok Perempuan Pesisir Tapak "Putri Tirang”. Kelompok ini berkegiatan dalam pengolahan hasil tambak dan hasil tangkapan nelayan. Putri Tirang juga memiliki peran sebagai pemberi pelayanan tempat penginapan pada tamu yang berminat serta memberikan pelayanan kuliner pesisir daerah ini;

Kedua, Kelompok Nelayan Tapak “Rukun Makmur”. Kelompok ini berperan sebagai penyedia jasa sarana perahu bagi pengunjung EEWM yang ingin berkeliling melihat hutan mangrove dan beberapa jenis fauna yang ada di kawasan ini; 
Ketiga, Kelompok Petani Tambak Tapak “Sido Rukun”. Kelompok ini berperan dalam penanaman dan perlindungan mangrove di kawasan EEWM Tapak Tugurejo. Kelompok juga berperan dalam pembuatan dan pemeliharaan APO.

Keempat, Kelompok Pengolah Sampah “ARGA”. Kelompok ini bertugas untuk mengolah sampah yang berada di Dusun Tapak dan kawasan EEWM.

Kelima, Kelompok Swadaya Masyarakat (KSM) “Mugi Makmur”. Kelompok ini berperan dalam pengelolaan MCK (lihat tabel 1).

\section{Pelaksanaan Peran Pemuda}

Berdasarkan Rencana Tata Ruang Wilayah (RTRW) Kota Semarang Tahun 20112031, zona berdasarkan pola ruang wilayah
Kota Semarang yaitu kawasan pantai berhutan bakau/ mangrove adalah kawasan pesisir laut yang merupakan habitat alami hutan yang berfungsi memberikan perlindungan kepada perikehidupan pantai dan lautan. Kelurahan Tugurejo ditunjuk sebagai prioritas satu dan berpotensi terhadap pengembangan lahan karena tersedianya embrio kawasan EEWM (DKP Kota Semarang, 2010). Pemerintah Kota Semarang melihat kemajuan dari proses rehabilitasi di wilayah pesisir Kota Semarang terutama Kelurahan Tugurejo yang sangat berpotensi untuk dikembangkan menjadi lahan konservasi yang berbasis EEWM. Pemerintah Kota Semarang dan DKP Kota Semarang mewujudkanya melalui penyusunan DED (Detail Engineering Design) EEWM di Kecamatan Tugu, Kota Semarang. Konsep dasar kawasan EEWM adalah kawasan wisata

Tabel 1. Pengembangan Perekonomian Masyarakat Di Dusun Tapak

\begin{tabular}{|c|c|c|}
\hline Kelompok Masyarakat & Tahun 2003 & Tahun 2014 \\
\hline Kelompok Prenjak & $\begin{array}{l}11 \text { orang pemuda } \\
\text { mempelopori } \\
\text { terbentuknya Prenjak } \\
\text { yang saat itu bernama } \\
\text { tim sebelas. }\end{array}$ & $\begin{array}{l}\text { (a) } 20 \text { Anggota berperan aktif sebagai pengelola kawasan EEWM sehingga } \\
\text { dibuat jadwal piket untuk menjaga pusat informasi, (b) sudah mempunyai } \\
\text { akta pengesahan dari Notaris dengan nama resmi "Prenjak Tapak", } \\
\text { (c) pendapatan pemuda sebagai pengelola kawasan EEWM berkisar } \\
\text { Rp.400.000-600.000 per bulan. }\end{array}$ \\
\hline $\begin{array}{l}\text { Kelompok Perempuan } \\
\text { Pesisir Tapak "Putri } \\
\text { Tirang”, }\end{array}$ & Belum ada kelompok & $\begin{array}{l}\text { (a) Beranggotakan sekitar } 24 \text { orang dengan anggota aktif } 16 \text { orang, (b) } \\
\text { ada } 2 \text { rumah penduduk yang dijadikan homestay untuk wisatawan dengan } \\
\text { pendapatan sekitar Rp.100.000-300.000. per bulan, (c) membuat olahan } \\
\text { makanan dari mangrove berupa kue kering, dodol, bolu dan brownies, (d) } \\
\text { membuat olahan hasil laut berupa bandeng presto, nugget, dan otak-otak, } \\
\text { (e) penghasilan yang didapatkan masih tentative sesuai pesanan }\end{array}$ \\
\hline $\begin{array}{l}\text { Kelompok Nelayan } \\
\text { Tapak “Rukun Makmur” }\end{array}$ & Kelompok vacum. & $\begin{array}{l}\text { (a) Diaktifkan kembali oleh Prenjak pada tahun 2008, (b) penyediaan } \\
\text { perahu berikut bahan bakarnya bagi wisatawan yang akan melakukan } \\
\text { ecotourism dengan pendapatan berkisar Rp. } 100.000 \text { satu kali melakukan } \\
\text { trip dalam ecotourism. }\end{array}$ \\
\hline $\begin{array}{l}\text { Kelompok Petani } \\
\text { Tambak Tapak "Sido } \\
\text { Rukun” }\end{array}$ & k vacuum & $\begin{array}{l}\text { (a) Diaktifkan kembali oleh Prenjak pada tahun 2009, (b) pelibatan } \\
\text { kelompok tani dalam paket wisata dan penelitian misalnya dengan } \\
\text { pendidikan pembuatan APO dan belanja ikan di tengah sungai. }\end{array}$ \\
\hline $\begin{array}{l}\text { Kelompok Pengolah } \\
\text { Sampah "ARGA", }\end{array}$ & Belum ada kelompok & $\begin{array}{l}\text { (a) Kelompok beranggotakan pemuda dari Rt } 03 \text { Dusun Tapak. Prenjak } \\
\text { melibatkan pemuda di luar komunitas agar terjalin komunikasi yang baik, } \\
\text { (b) pendapatan berkisar Rp. } 140.000 \text { dalam sekali pengolahan sampah } \\
\text { organik. }\end{array}$ \\
\hline $\begin{array}{l}\text { Kelompok Swadaya } \\
\text { Masyarakat "Mugi } \\
\text { Makmur” }\end{array}$ & elompok & $\begin{array}{l}\text { (a) Pembuatan kamar mandi bagi wisatawan dengan tanah Hak Milik } \\
\text { Prenjak, (b) pendapatan masih tentative }\end{array}$ \\
\hline
\end{tabular}

Sumber : Pengolahan data lapangan, Peneliti, 2014 
Fitriyani -- Peran Pemuda Dalam Mengembangkan Eco Edu Wisata Mangrove Dan Implikasinya Terhadap Ketahanan Lingkungan Daerah (Studi Pada Perkumpulan Pemuda Peduli Lingkungan "Prenjak" Dusun Tapak, Kelurahan Tugurejo, Kecamatan Tugu, Kota Semarang, Provinsi Jawa Tengah)

alam sebagai wadah untuk memberikan serta meningkatkan pengetahuan dan pengalaman pengunjung terhadap ekosistem mangrove dan interaksinya (budidaya perikanan tambak). Implementasi dari peran pemuda dalam mengembangkan EEWM dapat dilihat dari kegiatan yang telah dilakukan yakni :

\section{Peran Pemuda Prenjak dalam Indikator Pengembangan EEWM berupa Program Pengelolaan Ekowisata yaitu:}

Pertama, rehabilitasi lingkungan pesisir Tapak untuk mendukung kegiatan konservasi mangrove yaitu pembibitan, penanaman, pemeliharaan mangrove, pembuatan APO, dan perlindungan burung.

Kedua, peningkatan kapasitas organisasi Prenjak dalam pengembangan EEWM melalui kerjasama kemitraan dengan pihak lain untuk meningkatkan kapasitas anggota, memberikan beasiswa paket $\mathrm{B}$ dan $\mathrm{C}$ mengingat anggota Prenjak sebagian besar putus sekolah, dan memfasilitasi anggota untuk mengikuti berbagai macam pelatihan guna meningkatkan kapasitas anggota dalam mengembangkan EEWM.

Ketiga, potensi wisata Tapak Tugurejo diimplementasikan dalam pembuatan paket ecotourism dan pendidikan lingkungan yang dikemas secara baik dan berkelanjutan.

Kondisi awal: (1) hutan mangrove yang gundul, krisis, dan terlantar; tergerusnya daratan yang mengakibatkan penyempitan luasan tambak; abrasi dan rob yang menyebabkan hilangnya tambak, menurunnya kualitas air tambak secara drastis sehingga menyebabkan kuantitas dan kualitas produksi tambak menurun; kondisi lingkungan akibat pembangunan belasan industri di sekitar wilayah tersebut telah memperburuk keadaan karena keluaran limbah industri berupa limbah kimia, kondisi ini menyebabkan kualitas air menurun dan membahayakan ikan-ikan yang dibudidayakan dalam tambak. (2) Prenjak dalam mencapai visi dan misinya sadar memiliki keterbatasan atas pengetahuan (expertise) dan pembiayaan (finance), sebab jika dilihat latar belakang anggotanya memiliki tingkat pendidikan formal yang masih rendah. (3) Awalnya, Dusun Tapak merupakan dusun biasa tanpa ada kegiatan kepariwisataan. Kepedulian terhadap alam dan lingkungan juga masih minim terutama pada ekosistem mangrove dikarenakan masyarakat tidak mengerti manfaat mangrove yang sangat besar.

Peran pemuda dalam pelaksanaan program: (1) pembibitan, penanaman, dan pemeliharan mangrove, pembuatan Alat Pemecah Ombak (APO), dan perlindungan burung, (2) melakukan kerjasama dengan pihak lain untuk meningkatkan kapasitas anggota, memberikan beasiswa Paket B dan $\mathrm{C}$ mengingat anggota Prenjak sebagian besar putus sekolah, dan memfasilitasi anggota untuk mengikuti berbagai macam pelatihan guna meningkatkan kapasitas anggota dalam mengembangkan EEWM. (3) Prenjak membuat kegiatan EEWM lebih menarik dan beragam tanpa merusak lingkungan dan dapat dipilih sesuai kebutuhan wisatawan yakni susur hutan mangrove dengan perahu tradisonal, pengenalan/pendidikan jenis mangrove, bird watching, membibit dan menanam mangrove, panen ikan/gogoh, mengamati teknologi tepat guna APO, pasar ikan tengah laut, dan pre-wedding; pembuatan flyer yang berisi paket wisata dengan kegiatan belajar di alam memperkenalkan lingkungan hutan mangrove dengan segala kekayaan flora dan 
faunanya serta arti penting menjaga lingkungan dan keberlangsungan alam dalam hal ini hutan mangrove; pendidikan lingkungan; pembuatan media publikasi berupa website, blog, facebook, flyer untuk kampanye cinta lingkungan; pembuatan berbagai macam souvenir cantik khas kawasan mangrove dan mengikuti pameran.

Kondisi sekarang: (1) penghijauan dan konservasi mangrove. Teknologi tepat guna APO telah membuat wilayah tersebut aman dari abrasi/banjir rob. Adanya larangan berburu hewan di kawasan EEWM dan sekitarnya, adanya larangan untuk menebang pohon yang ada di lokasi EEWM terutama pohon mangrove, penghijauan dan hutan mangrove yang bertambah subur, pada akhirnya dapat menetralisir air yang tercemar oleh limbah sehingga kerusakan tambak dapat diminimalisir, dampak positifnya yakni kegiatan ekonomi masyarakat berjalan dengan lancar; (2) Anggota Prenjak selain mendapatkan pendidikan di lapangan secara langsung, mereka dapat menempuh pendidikan formal; berbagai pelatihan yang telah dilaksanakan, menimbulkan kepercayaan diri yang tinggi bagi anggota Prenjak. Prenjak dipercaya untuk melakukan tanggung jawab dalam berbagai macam kegiatan di kawasan EEWM dikarenakan menguatnya posisi tawar, dan Prenjak mendapatkan berbagai prestasi baik lokal maupun nasional; (3) Adanya penawaran paket wisata berwawasan lingkungan memberikan kesempatan kepada wisatawan untuk menjaga lingkungan. Adanya manajemen pariwisata berwawasan lingkungan membuat Dusun Tapak menjadi icon wisata baru di Kota Semarang dengan ciri khas Eco Edu Wisata.

\section{Peran Pemuda Prenjak dalam Indikator Pengembangan EEWM berupa Dukungan Masyarakat}

Kondisi awal: pada awal konsep ini dilaksanakan, terdapat masyarakat Tapak yang mendukung maupun tidak mendukung.

Peran pemuda dalam pelaksanaan program: (1) mengadakan pertemuan rutin dan gotong royong bersama secara temporal; (2) melakukan sosialisasi rutin terhadap masyarakat mengenai ekosistem mangrove beserta kegunaannya (3) melakukan pembiayaan lembaga secara mandiri melalui konservasi dan rehabilitasi pesisir Dusun Tapak dengan melakukan pembibitan mangrove yang tenaga kerjanya diambil dari lingkungan sekitar dan Sisa Hasil Usahanya dipergunakan bagi kepentingan peningkatan anggota dan kepentingan masyarakat, (4) membuka peluang ekonomi bagi setiap kelompok masyarakat yang ada di Dusun Tapak seperti Kelompok Petani Tambak Tapak “Sido Rukun”, Kelompok Nelayan Tapak “Rukun Makmur”, Kelompok Perempuan Pesisir Tapak “Putri Tirang”, Kelompok Pengolah Sampah “ARGA”, dan KSM “Mugi Makmur”.

Kondisi sekarang: Prenjak mampu menjadi pemimpin, pelopor, pencetus dan fasilitator di antara kelompok yang ada dan menjadi supervisor bagi pengunjung yang datang ke wilayah EEWM. Bisnis inklusif sebagai salah satu program jangka panjang Prenjak merupakan suatu cara penting untuk menjaga keberlanjutan perekonomian. Program pemberdayaan masyarakat yang dilakukan Prenjak tersebut saat ini telah mendapat dukungan dari masyarakat. Sinergitas yang dibangun oleh Prenjak mampu membuat bukti nyata bagi masyarakat bahwa konsep 
Fitriyani -- Peran Pemuda Dalam Mengembangkan Eco Edu Wisata Mangrove Dan Implikasinya Terhadap Ketahanan Lingkungan Daerah (Studi Pada Perkumpulan Pemuda Peduli Lingkungan "Prenjak"

Dusun Tapak, Kelurahan Tugurejo, Kecamatan Tugu, Kota Semarang, Provinsi Jawa Tengah)

EEWM dapat secara perlahan mengentaskan kemiskinan dan pengangguran di Dusun Tapak.

\section{Peran Pemuda Prenjak dalam Indikator Pengembangan EEWM berupa Sarana Prasarana}

Kondisi awal: Prenjak dalam mencapai visi dan misinya sadar memiliki keterbatasan atas pengetahuan dan pembiayaan. Dusun Tapak agar disebut sebagai sebuah destinasi pariwisata dalam kenyataannya memang belum sepenuhnya siap.

Peran pemuda dalam pelaksanaan program: (1) Prenjak bekerjasama dengan DKP Kota Semarang dalam pembuatan perahu viber melalui program PNPM Mandiri; (2) Prenjak membeli tanah dengan dana Sisa Hasil Usaha Prenjak untuk mendirikan pusat informasi EEWM yang digunakan sekaligus sebagai sekretariat Prenjak. (3) Pemerintah membangun infrastruktur berupa perbaikan jalan menuju kawasan EEWM dan pemfasilitasan bibit mangrove, (4) Prenjak bekerjasama dengan KSM “Mugi Makmur” dalam pengelolaan dan pendirian sarana MCK di atas tanah Hak Milik Prenjak yang berada tepat di belakang pusat informasi, (5) Prenjak mulai membeli alat-alat untuk kelengkapan Eco Edu Wisata setelah mendapatkan dana dari penjualan bibit mangrove, (6) Prenjak bekerjasama juga dengan DKP Kota Semarang dalam pembuatan tracking dan dermaga yang diperuntukkan bagi wisatawan yang datang ke kawasan EEWM.

Kondisi sekarang: adanya program pengadaan sarana prasarana tersebut membuat konsep EEWM yang sesungguhnya terwujud. Keinginan Prenjak dan masyarakat untuk mewujudkan pariwisata beserta sarana prasarana yang lengkap, dilaksanakan melalui usaha swadaya dan kerjasama dengan pihak lain.

\section{Peran Pemuda Prenjak dalam Indikator Pengembangan EEWM berupa Penggunaan Lahan}

Kondisi awal: belum terdapat lahan yang akan digunakan untuk kawasan EEWM

Peran Pemuda dalam Pelaksanaan Program: (1) Prenjak melakukan kemitraan dengan Pemerintah Daerah dalam mengelola daerah pesisir sebagai upaya untuk mewujudkan lahan konservasi mangrove; (2) Prenjak memandang penting untuk bermitra dengan pihak swasta, dikarenakan pihak swasta di Kota Semarang sangat memiliki pengaruh terhadap terwujudnya lahan konservasi mangrove di Kota Semarang. Berdasarkan data yang dikutip dari DKP Kota Semarang menyebutkan bahwa lahan yang pesisir di Kota Semarang 94\% telah berada ditangan pihak swasta. (3) Pada tahun 2012, Pemerintah Kota Semarang membuat DED EEWM untuk lahan konservasi mangrove di Kecamatan Tugu, Kota Semarang perkembangannya, baik permasalahan, potensi sumberdaya perikanan dan pesisir, (4) Pemerintah Daerah telah melakukan koordinasi dengan Badan Pertanahan Nasional untuk merencanakan perubahan status kepemilikan dan alih fungsi lahan untuk menjadi daerah konservasi mangrove. (5) DPRD Kota Semarang mengusulkan anggaran sebesar Rp 1.000.000.000,- (satu milyar rupiah) agar dianggarkan di APBD tahun 2012. Anggaran digunakan untuk melakukan pengadaan lahan kawasan konservasi mangrove di wilayah pesisir Kota Semarang dengan konsep EEWM (Bappeda, 2013).

Kondisi sekarang: belum terdapat hasil yang maksimal hingga kini karena lahan yang 
direncanakan oleh pemerintah dalam $D E D$ EEWM belum terwujud.

\section{Kendala Pemuda dalam Mengembangkan EEWM Tapak Tugurejo}

Kendala yang dihadapi pemuda dalam mengembangkan EEWM yaitu:

Pertama, Peran Pemuda Belum Maksimal. Faktor yang menjadi kendala yakni: (1) Perbedaan pemahaman pemuda mengenai urgensi pengembangan EEWM. Beragam pemahaman dan tingkat usia pemuda Prenjak menjadi tantangan tersendiri untuk dapat mengkomunikasikan program yang dijalankan agar semua warga dapat ikut serta mendukung kegiatan pengembangan kawasan EEWM tersebut. (2) Tidak meratanya semangat, idealisme dan komitmen pemuda dalam kegiatan sosial dan membangun Dusun Tapak. Semangat, idealisme dan komitmen untuk membangun daerah tersebut baru ada pada sebagian pemuda saja sedangkan pemuda lainnya masih bersikap apatis. (3) Keterbatasan keterampilan yang dimiliki pemuda. Berdasarkan data yang ditemukan di lapangan, keterampilan yang masih minim atau terbatas tersebut yakni keterampilan berbahasa asing, keterampilan berkomunikasi memandu wisatawan, keterampilan manajemen pengelolaan wisata, dan keterampilan dalam P3K dan manajemen safety procedure bagi wisatawan. (4) Kesulitan dalam menentukan skala prioritas tanggung jawab pemuda.

Kedua, Keterbatasan Anggaran dan Infrastruktur. Anggaran merupakan permasalahan klasik bagi suatu organisasi. Keterbatasan anggaran akan mempengaruhi pemenuhan sarana dan prasarana sehingga menjadi kendala tersendiri bagi pemuda.

Ketiga, Kondisi Lingkungan dan Sumber Daya Alam di Dusun Tapak Tugurejo. Kawasan
EEWM Tapak Tugurejo merupakan kawasan yang rawan terjadi banjir abrasi dan rob, dan seringkali terjadi kenaikan permukaan air laut. Kondisi ini menjadi sulit karena ditambah kerusakan ekosistem akibat tindakan manusia yang tidak bertanggung jawab.

Keempat, Kurangnya Dukungan dari Berbagai Pihak. Dukungan dari berbagai pihak merupakan aset yang dapat memperlancar upaya pengembangan kawasan EEWM Tapak Tugurejo. Adanya dukungan akan memudahkan pemuda untuk merealisasikan rencana pengembangan kawasan ekowisata.

Kelima, Kebijakan Pemerintah dalam Mewujudkan Daerah Konservasi Mangrove dan Status Kepemilikan Lahan. Belum adanya prioritas utama terhadap lingkungan dari Pemerintah Kota Semarang dalam upaya mewujudkan lahan konservasi di wilayah pesisir menjadi kendala tersendiri. Selain itu, status tanah yang akan dijadikan lahan konservasi merupakan tanah milik swasta (industri).

\section{Upaya Pemuda dalam Mengembangkan EEWM Tapak Tugurejo \\ Pertama, Peningkatan Peran Pemuda dalam Mengembangkan EEWM Tapak} Tugurejo, yaitu: (1) Menyamakan pemahaman pemuda terkait urgensi pengembangan $E E W M$ Tapak Tugurejo. Komunikasi adalah cara untuk meminimalisir kendala tersebut yaitu pembicaraan tentang kendala, penyebab dan solusinya. Selain itu, menyamakan visi, misi dan perbedaan karekter harus diupayakan, serta memberikan peran kepada setiap pemuda dan masyarakat untuk bisa terlibat dalam kegiatan pariwisata. (2) Penguatan semangat, idealisme dan komitmen pemuda untuk membangun Dusun Tapak. Semangat, idealisme dan 
Fitriyani -- Peran Pemuda Dalam Mengembangkan Eco Edu Wisata Mangrove Dan Implikasinya Terhadap Ketahanan Lingkungan Daerah (Studi Pada Perkumpulan Pemuda Peduli Lingkungan "Prenjak"

Dusun Tapak, Kelurahan Tugurejo, Kecamatan Tugu, Kota Semarang, Provinsi Jawa Tengah)

komitmen di antara pemuda menjadi pemersatu yang mendorong pemuda mengembangkan potensi daerah. (3) Meningkatkan keterampilan dan pendampingan kepada pemuda sehingga mendukung pengembangan kawasan EEWM Tapak Tugurejo yaitu pelatihan pemandu wisata, pelatihan Pertolongan Pertama Pada Kecelakaan (P3K) dan evakuasi korban, pelatihan keorganisasian, pelatihan komputer, pelatihan pengolahan makanan hasil laut dan promosi hasil olahan, pelatihan bahasa Inggris, dan pelatihan outbond. (4) Pembagian jadwal piket bagi anggota Prenjak sebagai upaya manajemen waktu dan skala prioritas pemuda. Tidak semua pemuda mempunyai waktu yang banyak untuk turut serta aktif berperan mengembangkan EEWM Tapak Tugurejo, untuk itu dibuatlah jadwal piket bagi pemuda untuk menjaga sekretariat pengelola. (5) Meningkatkan motivasi pemuda untuk mengembangkan EEWM melalui pemberian beasiswa pendidikan.

Kedua, Peningkatan anggaran dan infrastruktur melalui kerjasama dengan berbagai pihak. Berdasarkan hasil penelitian lapangan, anggaran yang masuk selama ini diperoleh dan digunakan untuk membiayai kegiatan berasal dari usaha Prenjak yakni (1) Sisa Hasil Usaha penjualan bibit mangrove; (2) penjualan paket ecotourism; (3) penjualan souvenir dan makanan olahan hasil mangrove yang temporal. Selain itu, dana untuk mengembangkan EEWM Tapak Tugurejo dilakukan dengan cara menjalin kemitraaan dengan berbagai pihak baik dari pemerintahan, LSM, maupun CSR/ Swasta.

Ketiga, Rehabilitasi dan Pelestarian Lingkungan dengan Konsep EEWM. Lingkungan memiliki nilai intrinstik yang jauh melebihi nilainya sebagai aset pariwisata. Oleh karenanya, agar dapat dinikmati oleh generasi mendatang dan agar dapat bertahan hidup untuk jangka panjang, lingkungan tidak boleh dipertaruhkan hanya karena pertimbangan jangka pendek.

Keempat, Mengikuti dan Memenangkan Perlombaan untuk Mendapatkan Dukungan Berbagai Pihak. Penghargaan yang diraih yaitu Juara II Lomba Adibakti Wina Bahari, Juara I Lomba Kelompok Pecinta Alam Provinsi, dan Juara II Lomba Kelompok Pecinta Alam Nasional.

Kelima, Audiensi, Seminar, Workshop serta Menjalin Kemitraan dengan Berbagai Pihak guna Mewujudkan Kebijakan Pemerintah terkait Pengadaan Lahan Konservasi Mangrove (EEWM) dan Status Kepemilikan Lahan.

\section{Implikasi Peran Pemuda dalam Mengembangkan Eco Edu Wisata Mangrove Tapak Tugurejo Terhadap Ketahanan Lingkungan Daerah}

Berdasarkan Undang-Undang Nomor 23 Tahun 1997 tentang Pengelolaan Lingkungan Hidup, unsur-unsur lingkungan hidup dapat dibedakan menjadi tiga, yaitu (1) unsur hayati (biotik) yaitu unsur lingkungan hidup yang terdiri dari makhluk hidup seperti manusia, hewan, tumbuh-tumbuhan dan jasad renik, (2) unsur fisik (abiotik) yaitu unsur lingkungan hidup yang terdiri dari benda-benda tidak hidup seperti tanah, air, udara, iklim dan lain-lain, (3) unsur sosial budaya yaitu lingkungan sosial dan budaya yang dibuat manusia yang merupakan sistem nilai, gagasan, dan keyakinan dalam perilaku sebagai makhluk sosial.

Unsur-unsur lingkungan hidup erat berkaitan dengan ketahanan lingkungan daerah yang merupakan bagian dari ketahanan nasional. Ketahanan lingkungan merupakan keamanan 
publik secara poporsional dari bahaya-bahaya lingkungan yang diakibatkan oleh proses-proses alamiah dan buatan manusia karena keteledoran, kecelakaan, salah kelola, atau kesengajaan. Ketahanan lingkungan mengkaji ancaman akibat kejadian lingkungan, kecenderungan ketahanan nasional dan unsur kekuatan nasional. Ketahanan lingkungan merupakan siklus pengelolaan sumberdaya alam menjadi produk, menjadi limbah, menjadi sumberdaya alam lainnya, dengan cara-cara yang sesuai untuk mewujudkan stabilitas sosial. Oleh karenanya, ketahanan lingkungan daerah merupakan pengelolaan lingkungan fisik di sekitar masyarakat untuk memenuhi kebutuhannya tanpa mengganggu cadangan ilmiahnya. Ketahanan lingkungan merupakan kebebasan dari instabilitas sosial akibat degradasi lingkungan (Soemarno, 2012).

Indikator ketahanan lingkungan daerah mengacu pada panduan untuk pengembangan dan pembangunan destinasi wisata yaitu konsep pengembangan pemukiman terpadu yang dikeluarkan oleh Kementerian Lingkungan Hidup (SK No. 4 Tahun 2000 tentang Panduan Penyusunan AMDAL Kegiatan Pembangunan Pemukiman Terpadu). Pengembangan yang berwawasan lingkungan harus memperhatikan lima kaidah sebagai berikut:

Pertama, ketersediaan Ekosistem. Berdasarkan indikator ketersediaan ekosistem, peran pemuda Prenjak dalam mengembangkan EEWM Tapak Tugurejo berimplikasi terhadap ketahanan lingkungan daerah dengan dampak positif berupa (1) terjaganya kelestarian alam denganpenanaman, pembibitan,dan pemeliharaan hutan mangrove sehingga ketersediaan ekosistem baik kuantitas maupun kualitasnya sangat baik. (2) Memiliki tambak budidaya bandeng sehingga dapat melestarikan fauna di sekitar kawasan EEWM. (3) Pembuatan teknologi tepat guna APO dari ban bekas telah menanggulangi abrasi, sehingga menjaga ekosistem di kawasan EEWM. (4) Diperhatikannya kawasan tersebut oleh akademisi dan pemerintah. Prenjak dan masyarakat Tapak harus selalu mewaspadai terjadinya bencana dengan mencegah atau menghindarkan bencana yang terjadi setiap waktu terhadap manusia atau makhluk hidup lainnya yang hidup dalam ekosistem tersebut. Akhirnya, komponen biotik dan abiotik dapat terjaga, kemudian terdapat ketahanan lingkungan daerah di Dusun Tapak.

Kedua, Penggunaan Energi yang Minimal. Kawasan EEWM Tapak Tugurejo di dalamya belum terdapat green construction atau bangunan yang ramah lingkungan dikarenakan memang belum terdapat pembangunan infrastruktur berupa bangunan di kawasan ini. Dalam DED EEWM telah terdapat perencanaan pembuatan kincir angin guna menghemat energi seperti dikatakan oleh Agus Khariswanto, staff Dinas Kebudayaan dan Pariwisata Kota Semarang:

“Menurut saya, indikator penggunaan energi
yang minimal belum terealisasi di Tapak
Tugurejo. Sebenarnya di dalam DED sudah
ada kincir angin sebagai pembangkit dan
penghemat energi, namun belum terealisasi
hingga saat ini. Jadi implikasi peran Prenjak
terhadap ketahanan lingkungan daerah
belum nampak” (Wawancara dengan Agus
Khariswanto, dilakukan pada 17 Desember
2014).

Detail Engineering Design (DED) EEWM tersebut belum terealisasikan, maka dapat disimpulkan bahwa peran pemuda Prenjak dalam mengembangkan EEWM belum berimplikasi terhadap ketahanan lingkungan daerah. Prenjak berusaha 
Fitriyani -- Peran Pemuda Dalam Mengembangkan Eco Edu Wisata Mangrove Dan Implikasinya Terhadap Ketahanan Lingkungan Daerah (Studi Pada Perkumpulan Pemuda Peduli Lingkungan "Prenjak" Dusun Tapak, Kelurahan Tugurejo, Kecamatan Tugu, Kota Semarang, Provinsi Jawa Tengah)

membatasi penggunaan energi namun belum menemukan alternatif energi. Selain itu, pembuatan kincir angin dalam DED EEWM belum terealisasikan.

Ketiga, Pengendalian Limbah dan Pencemaran. Dampak tersebut yaitu (1) keseimbangan ekologi lingkungan perairan pantai tetap terjaga, keberadaan mangrove dipertahankan oleh Prenjak dan penduduk karena mangrove dapat berfungsi sebagai biofilter limbah dan pencemar, agen pengikat dan perangkap polusi. (2) Adanya penghijauan menjadikan tambak lebih aman dari limbah sehingga budidaya tambak berjalan dengan lancar dan meminimalisir keresahan masyarakat yang akhirnya meningkatkan perekonomian petani tambak. (3) Saat ini penduduk sudah tidak kesulitan mendapatkan air bersih karena salinitas berkurang. (4) Pengendalian limbah dan pencemaran yang terjadi secara alami dengan adanya mangrove memunculkan keragaman hayati dalam hutan mangrove, yakni aneka jenis burung mulai datang dan tinggal disana. (5) Kawasan menjadi bersih dan teratur dengan adanya Kelompok Pengolah Sampah "ARGA". Akhirnya, komponen biotik dan abiotik dapat terjaga, kemudian terdapat ketahanan lingkungan daerah di Dusun Tapak.

Keempat, Kelanjutan Sistem Sosial Budaya Lokal. Pemuda Prenjak berperan dalam menjaga kelanjutan sistem sosial budaya lokal Dusun Tapak sehingga berimplikasi terhadap ketahanan lingkungan daerah. Dampak positif terlihat pada sosial budaya kemasyarakatan, perekonomian masyarakat yang meningkat, dan pengembangan kepemudaan di Dusun Tapak yang terlihat pada (1) penguatan ekonomi pemuda dengan berkurangnya pengangguran pemuda, (2) penguatan posisi tawar pemuda Prenjak di berbagai kalangan, dan (3) pemuda mempunyai aktivitas kesibukan yang positif terhadap lingkungan. Sosial budaya yang merupakan unsur lingkungan hidup menjadi kunci terciptanya ketahanan lingkungan daerah.

Kelima, Peningkatan Pemahaman Konsep Lingkungan Hidup. Dampak yang dirasakan terhadap peningkatan pemahaman konsep lingkungan hidup yakni (1) masyarakat, wisatawan, dan anak sekolah mengetahui pentingnya menjaga kelestarian alam melalui pemeliharaan mangrove, (2) secara edukasi kawasan hutan mangrove Tapak berperan penting dalam dunia pendidikan, karena menjadi laboratorium alam dan penelitian dari berbagai perspektif dapat dilakukan. Dampak tersebut terjadi karena program sosialisasi dan pelatihan berkelanjutan terhadap masyarakat Dusun Tapak; ecotourism dengan konsep $E E W M$ yakni menjaga fungsi lindung pada kawasan konservasi sebagai obyek wisata bahari berbasis masyarakat melalui wisata pendidikan, penelitian, dan pengembangan (litbang) serta wisata minat khusus; dan pendidikan lingkungan.

Indikator ketahanan lingkungan daerah yang dipadukan dengan teori etika lingkungan dan unsur-unsur lingkungan yakni abiotik, biotik, sosial budaya di atas, memberikan kesimpulan bahwa terdapat implikasi positif dari peran Prenjak terhadap ketahanan lingkungan daerah. Implikasi positif terdapat dalam empat indikator yaitu (1) ketersediaan ekosistem; (2) pengendalian limbah dan pencemaran; (3) kelanjutan sistem sosial budaya lokal; dan (4) peningkatan pemahaman konsep lingkungan hidup. Berdasarkan indikator penggunaan energi yang minimal peran Prenjak belum berimplikasi terhadap ketahanan lingkungan daerah. 


\section{SIMPULAN}

Peran pemuda Prenjak dalam mengembangkan Eco Edu Wisata Mangrove Tapak Tugurejo dapat dikatakan aktif. Pemuda Prenjak telah melaksanakan hak dan kewajiban dalam menjalankan perannya sesuai dengan Peraturan Daerah Kota Semarang Nomor 3 Tahun 2010 tentang Kepariwisataan. Peran pemuda dalam mengembangkan Eco Edu Wisata Mangrove terlihat dari indikator pengembangan ekowisata mangrove yang telah terpenuhi meliputi program pengelolaan ekowisata, dukungan masyarakat, sarana prasarana, dan penggunaan lahan.

Upaya yang dilakukan pemuda Prenjak dalam mengembangkan Eco Edu Wisata Mangrove Tapak Tugurejo berhasil meningkatkan ketahanan lingkungan daerah. Kondisi tersebut didorong oleh peran aktif pemuda Prenjak dan semuaunsur terkait dalam mendukung kelancaran pengembangan Eco Edu Wisata Mangrove serta mendorong terciptanya suasana kondusif bagi terwujudnya ketanahan lingkungan daerah. Kondisi yang tercipta meliputi empat indikator ketanahan lingkungan daerah yang berhasil diwujudkan yaitu (1) ketersediaan ekosistem; (2) pengendalian limbah dan pencemaran; (3) kelanjutan sistem sosial budaya lokal meliputi sosial budaya kemasyarakatan, perekonomian masyarakat, dan pengembangan kepemudaan Dusun Tapak; dan (4) peningkatan pemahaman konsep lingkungan hidup. Selanjutnya, belum terdapat implikasi peran pemuda Prenjak terhadap ketanahan lingkungan daerah dalam indikator penggunaan energi yang minimal. Hal tersebut dikarenakan terdapat beberapa program yang belum terealisasi dengan baik. Peran Prenjak dalam mengembangkan Eco Edu Wisata Mangrove berimplikasi positif terhadap ketahanan lingkungan daerah dikarenakan unsurunsur lingkungan meliputi abiotik, biotik, dan sosial budaya terjaga kelestariannya.

\section{DAFTAR PUSTAKA}

BappedaKotaSemarang dan Badan Pusat Statistik Kota Semarang, 2013, Semarang Dalam Angka 2012, Semarang: Bappeda Kota Semarang dan BPS Kota Semarang.

Dinas Kelautan dan Perikanan, 2010, Laporan Akhir Pemetaan Potensi, Kerusakan dan Model Rehabilitasi Kawasan Pesisir Kota Semarang, Semarang : DKP Kota Semarang.

--------------, 2012, Penyusunan Detail Engineering Design (DED) Eco Edu Wisata Mangrove di Kecamatan Tugurejo Kota Semarang, Semarang: DKP Kota Semarang.

Ermiliansa, D., Samekto, A., Purnaweni, H., 2014, "Peran Prenjak Dalam Mewujudkan Daerah Konservasi Berbasis Eco Edu Wisata Mangrove di Dusun Tapak Tugurejo Kota Semarang”, Ekosains, 6 (1), hal. 6268.

Fandeli, C., dan Mukhlison., 2000. PokokPokok Materi Pengusahaan Ekowisata, Yogyakarta: Fakultas Kehutanan Universitas Gadjah Mada.

Nugroho, I., 2011, Ekowisata dan Pembangunan Berkelanjutan, Yogyakarta : Pustaka Pelajar.

Rodger, 1998, "Leisure, Learning and Travel”, Journal of Physical Education, 69 (4), hal 28.

Santoso, N., 2000, "Pola Pengawasan Ekosistem Mangrove”, Jakarta: Makalah disampaikan pada Lokakarya Nasional Pengembangan Sistem Pengawasan Ekosistem Laut. 
Fitriyani -- Peran Pemuda Dalam Mengembangkan Eco Edu Wisata Mangrove Dan Implikasinya Terhadap Ketahanan Lingkungan Daerah (Studi Pada Perkumpulan Pemuda Peduli Lingkungan "Prenjak" Dusun Tapak, Kelurahan Tugurejo, Kecamatan Tugu, Kota Semarang, Provinsi Jawa Tengah)

\section{Internet}

Soemarno, 2012, Kompendium Ketahanan Lingkungan Hidup, PSLP-PPSUB (Internet), (http://marno.lecture.ub.ac. id/author/marno/page/92), (diakses 20 Desember 2014).

\section{Undang-Undang dan Peraturan}

Undang-Undang Nomor 23 Tahun 1997 Tentang Pengelolaan Lingkungan Hidup
Keputusan Menteri Negara Lingkungan Hidup Nomor 4 Tahun 2000 Tentang Panduan Penyusunan AMDAL Kegiatan Pembangunan Pemukiman Terpadu Peraturan Daerah Kota Semarang Nomor 3 Tahun 2010 Tentang Kepariwisataan

\section{Wawancara}

1. Agus Karisuranto: Dinas Kebudayaan dan Pariwisata 


\begin{tabular}{lll}
\hline VOLUME 21 & No. 2, 25 Agustus 2015 & Halaman 142-144 \\
\hline
\end{tabular}

\section{INDEKS}

A

abrasi 129, 131, 133, 134, 136, 138

administrasi 92, 93, 99, 119, 122, 125

agraris 108,113

Aksesibilitas i, 61, 62, 64, 65, 67, 71, 77

aksi unjuk rasa ii, 89, 90, 91, 92, 93, 94, 97, 99, 100, $101,102,103,104,105$

akuntabilitas 121, 123, 125, 126

Anggota Kepolisian Resort Kota Yogyakarta 90, 91, 101, 102, 104, 105

aspirasi rakyat 67

\section{B}

Badan Pertanahan Nasional 111, 135

bahan bakar 79, 86, 87

Bak 84, 85

bakteri 79

beras 108, 109, 113, 114, 115, 116, 117

bibit padi 117

biofilter 139

biogas ii, 78, 79, 80, 81, 82, 83, 84, 85, 86, 87

D

daerah otonom 119

daerah pemekaran 119

degradasi 129, 138

demokrasi 63, 66, 67, 72, 73, 74, 76

Desa Mandiri Energi 79, 87, 88

diskresi 89

disabilitas ii, 61, 62, 63, 64, 65, 66, 67, 68, 69, 70, $71,72,73,74,75,76,77$

Diskepenak 80, 81, 82, 83, 84

diskresi kepolisian 90, 98, 102

\section{$\mathbf{E}$}

Eco Edu Wisata Mangrove i, 128, 129, 130, 137, 140 eduwisata 130

Efektivitas i, 78, 79, 81, 82, 83, 86, 87

efisien 79, 119, 122, 125

ekologi 139 ekosistem 128, 129, 133, 134, 136, 138, 139, 140

ekowisata 128, 130, 131, 136, 140

embrio 129,132

energi ii, 78, 79, 81, 83, 84, 87, 109, 113, 138, 139, 140

energi alternatif biodigester 79

energi terbaharukan $78,79,87$

e-procurement ii, 118, 119, 120, 121, 122, 123, 124, 125, 126, 127

\section{$\mathbf{F}$}

fauna 131,138

fermentasi 79

fermentasi bahan organik 79

flora 133

G

gejolak sosial 63

genset $78,83,84,85,86$

gundul 133

H

habitat 131, 132

Hak Asasi Manusia 62, 77

Hambatan Fisik 62

Hambatan Informasi 62

Hambatan Legal 62

Hambatan Sikap 62

hewan 134, 137

Hukum pidana 90

\section{I}

infrastruktur 109, 124, 126, 135, 137, 138

instalasi biogas 80,81

internet 122, 123, 124, 126

intervensi 72, 102, 104, 119, 127

investor 112

$\mathbf{K}$

Kantor Ketahanan Pangan 80, 114, 115 
kayu bakar 86

kebutuhan energi 78, 79, 81, 83, 84

kebutuhan masyarakat 119

Kebutuhan Perumahan 107, 112

kelestarian 129, 138, 139

kelompok tani 80, 81, 85, 86, 117, 132

Kementerian Lingkungan Hidup 80, 81, 82, 83, 84, 138

Kemerdekaan Menyampaikan Pendapat 91, 105

Kemerdekaan Menyampaikan Pendapat di Muka Umum 91

kepentingan politik 72, 76

kepentingan umum 90, 91, 95, 98, 99, 104

kepercayaan publik 61, 76, 119

kepolisian ii, 89, 90, 91, 96, 98, 102

Kepolisian Daerah 96

Kepolisian Negara Republik Indonesia i, 90, 91, 98, 105

Kepolisian Resort i, 89, 90, 91, 96, 101, 102, 104, 105

kerusuhan 103

kerusuhan massa 103

ketahanan energi ii, 78

ketahanan lingkungan daerah ii, 128, 129, 130, 137, 138, 139, 140

ketahanan pangan ii, 107, 108, 109, 115, 117

ketahanan tata pemerintahan daerah ii, 118, 120, 123, 125, 126, 127

ketahanan wilayah ii, 89, 90, 91, 102, 103, 105

ketegangan 93

ketersediaan dan pemanfaatan biogas 81, 82, 86

ketersediaan pangan 109

konservasi 129, 130, 131, 132, 133, 134, 135, 136 , 139

konsumsi 108, 109, 114, 115, 116

Konversi 109, 114

konversi lahan 113, 129

korban 90, 104, 137

krisis energi 78, 79

kualitas air 129, 133

L

lahan sawah ii, 107, 108, 109, 110, 111, 112, 113, 115, 116

lelang 119, 122, 126, 127

limbah 79, 83, 84, 85, 86, 87, 128, 129, 131, 133, $134,138,139,140$

limbah industri 129, 133

limbah kimia 129, 133

limbah peternakan 79

limbah rumah tangga 129

logistik 121, 122

Luber Jurdil 66, 67, 72, 76

\section{$\mathbf{M}$}

mahasiswa ii, 61, 63, 64, 65, 66, 67, 68, 69, 70, 71, 72, 73, 75, 76, 97, 100, 103

massa aksi 93, 94, 96, 101

media sosial 92

modenisasi desa 113

motif 97,98

\section{$\mathbf{O}$}

obyek wisata bahari 130, 139

Organisasi Perangkat Daerah 124

$\mathbf{P}$

pabrik-pabrik 109

panen 82, 109, 114, 133

pariwisata 129, 130, 134, 135, 136, 137

partai politik $67,68,74,75$

partisipasi politik 63, 64, 65, 66, 71, 72

Pedoman Pengendalian Massa 93, 94, 105

pelanggaran 90, 101, 102, 104, 105

pemanfaatan ii, 78, 79, 81, 82, 83, 84, 85, 86, 87

Pembangunan 80, 81, 86, 88, 129, 138, 140, 141

pemblokiran jalan 103

pemerintahan daerah ii, 118, 120, 121, 123, 125 , 126, 127

Pemilu i, 61, 62, 63, 64, 66, 67, 68, 69, 70, 71, 72, $73,74,76,77$

penanganan aksi unjuk rasa 89, 90, 91, 94, 100, 101, 102, 103, 104

pencemaran 84, 85, 128, 129, 131, 139, 140

pendekatan kekuatan 100

pendekatan persuasif 100

pendidikan politik 65, 66, 71, 75

penegak hukum 90, 105

pengalihan fungsi ii, 107, 108, 110, 111, 112, 113, 116

pengendalian 85, 94, 96, 102, 116, 128, 139, 140

pengrusakan 103

pengunjuk rasa 90, 92, 94, 95, 99, 101, 102, 103 , 104, 105

penundaan usia perkawinan 116

peralatan standar 96, 102

peran pemuda ii, 128, 129, 130, 133, 138, 140

peran politik 61,76

perkembangan industri 107, 112

persepsi ii, 61, 63, 64, 65, 66, 67, 68, 69, 72, 73, 75, 105, 123, 124, 125

personil Intelijen 93

pertanian $79,108,109,110,111,113,115,116,117$, 129

pertimbangan moral 90

Pertumbuhan Penduduk 107, 112 
Perwira Pengendali 93

Petani 107, 109, 113, 116, 132, 134

peternakan 79, 86

Polisi 90, 91, 93, 94, 95, 98, 99, 100, 101, 102, 103, 104, 105

polusi 139

preventif 90, 91

produk sampingan negatif 129

produksi ii, 82, 84, 103, 107, 108, 109, 113, 114, 115, 116, 129, 133

Produksi Padi i, 108, 113, 114, 115

produktivitas 114, 116

proses produksi 103, 109

\section{$\mathbf{R}$}

reformasi administrasi 119

rehabilitasi 132, 133, 134

Rencana Detail Tata Ruang 111, 113

represif 90, 91

rob 129, 131, 133, 134, 136

\section{S}

sasaran aksi 93, 96, 102, 103

sektor non pertanian 108, 110

semak 131

Sikap politik 65, 66

Sinergi 131

sistem politik 66, 74

sistem sosial budaya lokal 128, 139, 140

stabilitas politik 66, 67, 75 sumberdaya alam 130, 138

Sumber energi 79, 87

supervisor 134

surat suara 62

Surat Tanda Terima Pemberitahuan 96

Susenas 108, 109, 113, 114

\section{$\mathbf{T}$}

tambak 129, 131, 133, 134, 138, 139

teknologi informasi dan komunikasi 120

teknologi tepat guna 133, 138

tindakan anarkis 103

transparan 119, 121, 122, 124, 126

transparansi 123, 124, 125, 126

tunadaksa 70,71

tunanetra 62, 69, 71

tunarungu-wicara 69, 70, 71

$\mathbf{U}$

Unit Layanan Pengadaan Barang dan Jasa 118, 120 urbanisasi penduduk 116

V

volume gas 84

W

wilayah pesisir 129, 130, 131, 132, 135, 136

wisatawan 100, 103, 132, 133, 134, 135, 136, 139 